BP WALENTY WÓJCIK

\title{
CENNIEJSZE RĘKOPISY BIBLIOTEKI SEMINARIUM DUCHOWNEGO W SANDOMIERZU
}

\section{CHARAKTERYSTYKA CAEOSCI ZBIORU}

W literaturze naszej powtarza się twierdzenie, iż okres nowożytny dziejów Kościoła i teologii w Polsce nie został dotąd wystarczająco zbadany ${ }^{1}$. Przyczyną tego stanu jest przede wszystkim ogrom źródeł i opracowań teologicznych, które pozostają nadal w rękopisach, nieraz trudno dostępnyich albo $\mathrm{w}$ ogóle nieznanych. Celem niniejszej publikacji jest poinformowanie o manuskryptach, które bądź to ze zbiorami poklasztornymi, bądź z darami duchowieństwa dostały się do Biblioteki Seminarium Duchownego w Sandomierzu.

Opracowanie wyoldrębnionych kodeksów rękopiśmiennych planował wlaściwy organizator tej biblioteki - ks. Andrzej Wyrzykowski ${ }^{2}$. Praca ta została w pełni podjęta dopiero po skatalogowaniu zaległych druków. W latach 1954-1958 przeprowadzono inwentaryzacje wszystkich manuskryptów w liczbie 1825. Są to kodeksy o charakterze bibliotecznym. Jedynie $\mathrm{w}$ dziale historii Kościoła i prawa kanonicznego trzeba było z konieczności ${ }^{3}$ zatrzymać niektóre materiały archiwalne jak pojedyncze księgi metrykalne, wizytacyjne i sądowe sprzed XIX w., księgi rachunkowe, dawne katalogi bijblioteczne, teczki i wiązki z dokumentami i pismami w sprawach gospoldarczych, rodzinnych itp. Archiwalia te dotyczą przeważnie klasztorów zniesionych w XIX w. oraz nieistniejących już

1 Por. ks. A. Klawek: Zarys dziejów teologii katolickiej w Polsce. Kraków 1948 s. 19.

2 Por. ks. W. Wójcik: Włączenie zbiorów poklasztornych do Biblioteki Seminarium Duchownego w Sandomierzu. Archiwa, Bibliot. kośc. T. 1: 1960 z. 2 s. 65.

3 Archiwum Kurii Diecezjalnej obejmuje zasadniczo akta od założenia diecezji w 1819 r. Na przyjęcie akt innych instytucji kościelnych nie pozwala szczupłość lokalu. W tej samej sytuacji jest Archiwum miejscowej Kapituly Katedralnej. 
organizacji i instytucji kościelnych. Część z nich wymaga jeszcze dokładniejszego opracowania.

Spośród ustalonych jednostek rękopiśmiennych 36 powstało przed r. $1500,17 \mathrm{w}$ XVI w., $293 \mathrm{w}$ XVII, $621 \mathrm{w}$ XVIII, $522 \mathrm{w}$ XIX i 336 w XX w. Możemy także wyróżnić 'w całości 675 rękopisów lacińskich, 1121 polskich i 29 kodeksów napisanych $w$ innych językach nowożytnych.

Zbiór rękopisów został ustawiony $w$ oszklonych szafach. Przy porządkowaniu całości uwzględniono przede wszystkich treść kodeksów. Wyróżniono poza filozofią przedmioty z zalkresu teologii systematycznej, historycznej i praktycznej. Poszczególne grupy obejmują więc teologię dogmaityczną, moralną, ascetyczną, biblistykę, historię Kościoła, prawo kanoniczne, liturgię, homiletykę i. katechetykę. Na końcu ustawiono dzieła z zakresu literatury pięknej i przedmiotów świeckich ${ }^{4}$.

Dział filozofii obejmuje 145 rękopisów. W tym 53 powstało

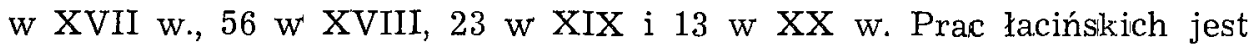
124, polskich 21. Pod względem treści można wyróżnić około 40 dzieł z logiki i dialektyki, 60 dotyczących wstępu (prolegomena), psychologii (de anima), ontologii i teodycei, 24 fizyki i kosmologii, 6 etyki, 7 komentarzy do dzieł Arystotelesa, 5 z zakresu historii filozofii oraz 3 showniki fillozoficzne. Poza dwiema ostatnimi grupami są to zazwyczaj skrypty szkolne, pissane przez słuchaczy podczas wykładów kursu filozofii scholastycznej w Akademii Krakowskiej i w szkołach zakonnych. W 55 kodeksach zaznaczono imiona i nazwiska wykładowców. W niektórych ujawnili się także uczniowie spisujący wykłady. Są też pojedyncze rozprawy uniwersyteckie z XIX i XX w. Posiadany zespół kodeksów filozoficznych pochodzi przeważnie $z$ bibliotek po skasowanych klasztorach: bernardynów w Opatowie, Paradyżu i Radomiu, dominikanów w Klimontowie, filipinów w Studziannie i pijarów w Radomiu. Część dzieł dostała się z księgozbioru manisjonarzy w Skrzynnie oraz z darów ks. Marcina Jasińskiego ${ }^{5}$, ks. Franciszka de Szwarcemberg Czernego ${ }^{6}$ i in.

Z dziedziny teologi i dogmatycznej posiada Biblioteka 94

4 Całość otrzymała numerację ciąglą od 1 do 1825. Dla odróżnienia od identycznej numeracji druków wprowadzono pomocniczo jako drugi człon sygnatury wielkie litery: A - ascetyka, B - biblistyka, C - homiletyka, D - teologia dogmatyczna, E - teologia moralna, F - filozofia, G - historia Kościola, I - prawo, J- prawo kanoniczne, $\mathrm{K}$ - katechetyka, L - liturgia, $\mathrm{E}$ - literatura. Inne przedmioty oraz przybytki otrzymują literę $R$ przed cyfra numeracji ciąglej. Jeśli $\mathrm{w}$ jednym kodeksie zszyto karty $\mathrm{z}$ pracami $\mathrm{z}$ różnych dziedzin, rękopis umieszczony został $w$ kolejności należnej pierwszej pozycji. Treść dalszych prac uwidoczni katalog. 271 kodeksów i teczek oraz około 2 C0 utworów muzycznych polskich i obcych oddano do zmikrofilmowania Bibliotece Narodowej w Warszawie.

5 Ks. J. W iśni'e W ski: Katalog prałatów i kanoników sandomierskich. Radom 1928 s. $92-93$.

6 Tamźe s. 45 . 
kodeksy: 37 z XVII w., 38 z XVIII, 14 z XIX i 5 z XX w. Rękopisów łacińskich jest 79 , polskich 15 . Wyróżnić w nich można 57 opracowań poszczególnych traktatów teologii dogmatycznej specjalnej oraz 21 komentarzy do dziel: Piotra Lombarda, św. Tomasza z Akwinu i Duns Szkota. W samych tytułach opracowań zaznaczali piszący, że chodzi o traktat według św. Tomasza czy Duns Szkota. Poza wyjątkami zbiór obejmuje skrypty szkolne. Jedynie w 26 wypadkach umieścili piszący nazwiska wykładowców. Co się tyczy proweniencji, to poza księgozbiorami wymienionymi przy dziale filozofii dodać tu trzeba pojedyncze egzemplarze z biblioteki kolegium jezuitów w Sandomierzu, miechowitów w Skaryszewie oraz paulinów w Beszowej.

Do działu teologii moraln ej zakwalifikować można według dzisiejszych kryteriów 61 pozycji. W tym 1 przypada na XV w., 15 na XVII, 23 na XVIII, 15 na XIX i 7 na XX. W języku łacińskim napisano 53 kodeksy a $8 \mathrm{w}$ języku polskim. Są to w znacznej większości opracowania poszczególnych traktatów. Kilka dzieł przypada na komentarze i rozwiązania kazusów. Jest 1 słownik pojęć teologiczno-moralnych. Poziom opracowań nie wykracza poza ramy tradycyjnego kur'su szksolnego. $\mathrm{Na}$ 10 kodeksach umieszczono imiona i nazwiska wykładających profesorów. Zestawienie notatek proweniencyjnych wskazuje, że do wspomnianych poprzednio księgozbiorów trzeba dodać bibliotekẹ klasztoru reformatów w Solcu nad Wisłą.

Jako zbiór kodeksów wyróżnia się dział a s c e ty k i z 303 pozycjami. Zestawienie chronologiczne wykazuje, że z XV w. pochodzą 2 rękopisy, z XVII -55, z XVIII $-165^{7}$ ai z XIX i XX -18 . Dzieł lacińskich jest tylko 39, polskich 264. Pod względem treści można wyodrębnić 131 pozycji zawierających rozmyślania na poszczególne dni roku i podczas rekolekcji, 17 podręczników teologii ascetycznej, 5 opracowań hagiograficznych oraz 150 modlitewników. Kodekșy te powstały przeważnie przez przepisyywanie $\mathrm{z}$ innych rękopisów lub tłumaczenie $\mathrm{z}$ języków abcych: z laciny a w XVIII i XIX w. i z języka francuskiego. Jedynie w 18 wypadkach zauważyć można nazwiska autorów lub tłumaczy. Odpisy te przeznaczone były do użytku zakonnic. Wydaje się, że do zbioru weszły niemal w komplecie dzieła po klasztorze benedyktynek w Sandomierzu. Napisy na kodeksach wiskazują, że posiadały one księgozbiór ascetyczny dla osób przebywających $w$ klasztorze, tzw. bibliotekę pospolita, następnie zbiór książek przeznaczonych tylko dla zakonnic - bibliotekę górną oraz kodeksy do użytku ksieni czy też zakonnic modlących się

7 Kodeks A 134 zawiera litanię z XVIII w. do bł. Mẹczenników Sandomier. skich. Jest $w$ projekcie opracowanie całości tego zbioru zgodnie z postulatami, które wysunąı Karol Górski: Zagadnienie edycji źródel do dziejów życia wewnętrznego w Polsce. Archiwa, Bibliot. kośc. T. 1: 1960 z, 2 s. 45-49. 
w chórze. Notatki na kartach tytułowych świadczą o darowiznach książek dla sióstr oraz o egzemplarzach będących prywatną własnością poszczególnych benedyktynek. Poza miejscowym klasztorem benedyktyńskim pojedyncze egzemplarze pochodzą od bernardynów, filipinów, jezuitów, kamedułów w Rytwianach i pijarów. Spośród innych ofiarodawców wyróżnia się ks. Jan Wiśniewski.

Do dziedziny biblistyki zaliczyć można tylko 36 kodeksów. Z okresu do $r$. 1500 pochodzą 4 rękopisy, z XVIII w. -2 , z XIX -24 i z XX - 6. Po łacinje napisano 24 prace a 12 po polsku. Poza 4 rękopisami średniowiecznych tekstów biblijnych reszta obejmuje introdukcje do nauki Pisma św. i komentarze służące klerykom w miejscowym seminarium duchownym oraz $w$ innych szkołach teologicznych. Kodeksy pochodzą przeważnie z darów księży diecezjalnych.

Dział histori i Kości oła obejmuje 613 pozycji, w tym 4 zXVw., 10 z XVI, 56 z XVII, 110 z XVIII, 248 z XIX i 185 z XX w. Język łaciński reprezentuje 110 pozycji, polski 480, a inne języki nowoizytne 23 . Poza kodeksami i zeszytami wyróżnić można 138 wiązek i teczek $z$ doikumentami, wycinkami z gazet, pismami i poszytami zawierającymi przeważnie materialy archiwalne. Pod względem treści kodekssy zawierają źródła historyczne lub ich odpisy, np. kopie tzw. kroniki koprzywnickiej do pierwszej polowy XVII w. i jej kontynuację ${ }^{8}$, dawne opracowania historii Polski i historii Kościoła Powszechnego, rękopisy prac z monografiami poszczególnych miejscowości, parafii, dekanatów itp. Część manuskryptów dotyczy prac ogłoszonych już drukiem. Znaczna ilość pism ma charakter pamiątek, zwłaszcza po poszczególnych księżach, nie przedstawia natomiast wartości naukowej. Zestawienie notatek proweniencyjnych uwidacznia przede wszystkim wielki wkład ks. Jana Wiśniewskiego. Jak wskazują jego własnoręczne dedykacje z lat 1910—1943, odsyłał on rękopisy do Bibliateki Seminarium po wykorzystaniu ich do opracowania swych „monografii dekanatów“, zwłaszcza z terenu diecezji sandiomierskiej ${ }^{9}$. Są też dary innych osób oraz pisma przekazywane po śmierci księży. Spotyka się także materiały historyczne odnoszące się do niektórych klasztorów skasowanych w $1864 \mathrm{r}$.

$\mathrm{Na}$ dział praw a przypada 138 pozycji. Poza kilkunastoma rękopisami z dziedziny prawa polskiego reszta dotyczy prawa kanonicznego. Z XV w. są 2 kodeksy, z XVI - 3, z XVII - 26, z XVIII - 65 i z XX 14. 111 kodeksów napisano po łacinie a 27 po polsku. Pod względem treści wyróżniają się skrypty szkolne odnoszące się do poszczególnych trakta-

8 Dar ks. Stanisława Puławskiego, proboszcza w Koprzywnicy. Przedstawia dzieje tamtejszego klasztoru cystersów.

a Poza tym ulożono w odrębnej szafie ofiarowane przez ks. J. Wiśniewskiego poszyty z materiałami do historii poszczególnych parafii. 
tów kanonistycznych, podręczniki prowadzenia procesów (praxis processus) oraz liczne rękopisy konstytucji, reguł i przywilejów zakonnych. W 9 wypadkach podano autorów komentarzy do poszczególnych ksiąg Dekretałów czy innych tekstów prawnych. Jest też kilka ksiąg $z$ formularzami czynności prawnych: administracyjnych i sądowych. Ze źródeł proweniencyjnych poza wyliczonymi klasztorami i poszczególnymi ofiarodawcami na wzmiankę zasługuje dawne archiwum $w$ Mściowie pod Sandomierzem.

$\mathrm{Z}$ zakresu 1 it u rgi i znajduje się w Bibliotece 121 rękopisów: 3 z XV w., 1 z XVI, 18 z XVII, 69 z XVIII, 26 z XIX i 1 z XX w. ${ }^{10}$ Pism łacińskich jest 77 , polskich 43 i 1 włoskie. Pod względem treści są to księgi liturgiczne $\mathrm{i}$ fragmenty $\mathrm{z}$ nich: rytuały, ceremoniały, kancjonały, rubrycele, części oficjum brewiarzowego, hymny itp. Stosunkowo liczne teksty $\mathrm{w}$ tłumaczeniu polskim oraz notatki proweniencyjne świadczą, iż kodeksy te były $w$ użyciu miejscowych benedyktynek. Wniosek ten potwierdzają teczki $\mathrm{z}$ nutami używanymi $\mathrm{w}$ chórze tegoż klasztoru. Zawieraja one prace nieznanych kompozytorów polskich i obcych ${ }^{11}$. Pojedyncze kodeksy pochodzą $z$ innych klasztorów oraz z kościołów diecezji.

Dział homiletyki abejmuje 160 pozycji: $\mathrm{z}$ XV w. $-16^{12}$, z XVI - 2, z XVII - 22, z XVIII -60, z XIX - 48 i z XX - 12 . Kazań i opracowań łacińskich jest 60, polskich 100. Wyróżnić należy 23 pođręczniki retoryki. Resztę stanowią kazania i materiały homiletyczne. Na podstawie napisów na kodeksach sprzed XIX w. możemy ustalić nazwiska 13 autorów i kaznodziejów. Rękopisy pochodzą w znacznej części z klasztoru pijarów w Radomiu, filipinów w Studziannie, kanoników regularnych w Bogorii i mansjonarzy w Skrzynnie. Mniejszą

10 Gradualy formatu wielkiego folio zostaly skatalogowane w r. 1908 i ulożone wraz $z$ drukami tych rozmiarów.

11 Nazwiska ich i tytuły utworów ogłosił ks. W. S wierczek ClM: Rękopiśmienne zabytki dawnej muzyki w Bibliotece Seminarium Duchownego w Sandomierzu. Kron. Diec. sandom. R. 52: 1959 s. 217-222, 284-288, 304-310, 340-342, 374-377; R. $53: 1960$ s. $26-30,56-60,90-94,148-152,178-181$. Do ważniejszych pozycji należą: G. G. Gorczycki - „Laetatus sum“ z 1730 r. (wyd. ks. W. S w i e rczek, Kraków 1958; wykonał chór "Filharmonii Poznańskiej pod dyrekcją Stefana Stuligrosza w $1959 \mathrm{r}$. W Poznaniu, w $1960 \mathrm{r}$. w Warszawie i za granica oraz chór kameralny Filharmonii Narodowej w Warszawie pod dyrekcją Jana Wierszyłowskiego w r. $1960 \mathrm{w}$ Warszawie); przygotowuje się wydanie w Pol. Wydawnictwie muzycz.: S. S. Szarzyński - „Veni Sancte“ z 1697 r. oraz M. H. Wronowicz - "Lauda Sion" z 1690 r.; kolęda, motet, msza i nieszpory J. Szczurowskiego z $1741 \mathrm{r}$. będą omówione przez $\mathrm{Z}$. Szweykowskiego z Krakowa w monografii o tym kompozytorze; "Symfonia“ F. B. Bohdanowicza z 2 pol. XVIII w. będzie wykonana przez Filharmonie Narodowa $w$ Warszawie; poza tym na wzmiankę zasługuja motety Józefa F. A. J. Kobierkiewicza; pod względem muzycznym wartość przedstawiają liczne kolędy i pastorałki.

12 Kodeks z kazaniami sygn. C 423 zawiera naklejony na drewnianej okładce tekst „Bogurodzicy“ z polowy XV w. Por. nr 64. 
wartość posiadają szkice kazań i przemówień z XIX i XX w. pisane w zeszytach lub na kartkach. Ofialrowane one zostały przewaznie przez. rodziny zmarłych księży.

Z zakresu $\mathrm{k}$ a te ch ety $\mathrm{k}$ i wyodrębnić można 12 kodeksów, w tym 8 z XVIII w. i 4 z XIX. Są to prace w języku polskim. Pochodzą one w większości z biblioteki pijarów radomskich.

Do działu I i te ra tu r y należy 39 pozycji: 1 z XVI w. ${ }^{13}, 3$ z XVII, 7 z XVIII, 22 z XIX i 6 z XX w. Poza 10 kodeksami łacińskimi jest 28 prac w języku polikim i $1 \mathrm{w}$ obcym języku nowożytnym. Zawierają one oryginały lub odpisy prac literackich. Gdy chodzi o proweniencje, to poza jezuitami sandomierskimi i pijarami z Radomia przeważają ofiarodawcy pojedynczy $\mathrm{z}$ ks. J. Wiśniewskim ná czele.

Do grupy "r ó żn y c h" zaliczono 103 kodelssy: 4 z XV w., 8 z XVII, 26 z XVIII, 33 z XIX i 32 z XX w. Eacinę reprezentuje 29 prac, język polski 70, inne języki nowożytne 4. Pod względem treści wymienic trzeba odpisy dzieł patrystycinych, podręczniki gramatyki, słowniki, prace z zakresu geografii, w'spomnienia z podróży, fragmenty opracowań z dziedziny nauk przyrodniczych $\mathrm{i}$ in. ${ }^{14}$ Uwidocznione są nazwiska 6 autorów. Rękopisy te pochodzą częściowo z klasztoru pijarów radomskich. Poza tym zestawienie ofiarodawców wyłkazuje kilkanaście na'zwìsk księży z diecezji sandomierskiej.

\section{OPIS REKOPISÓW}

Badaczy historii szkół kościelnych i teologicznych w Polsce od XVI do XX w. zainteresuja nazwiska i dzieła pisarzy czy nawet tylko profesorów, po których zachowały się streszczenia wykładów dokonane przez słuchaczy. Znaczenie będzie mieć również wskazanie ośrodków, w których powstały poszczególne kodeksy.

Niniejsze zestawienie obejmuje jedynie te rękopisy, przy których można $\mathrm{z}$ pewnością ustalić na podstawie kryteriów zewnętrznych ${ }^{15}$ nazwisko autora lub przynajmniej miejsce powstania dzieła. Poza rękopisami pochodzącymi od nieznanych autorów i $z$ nieustalonych środowisk, pominięte zostały kodeksy ogłoszone już drukiem ${ }^{16}$, tłumaczenia

19 Poza kopiarzem poematów Anüreja Krzyckiego z 1570 r. na uwagę zasługuje rękopis C. K. Norwida pt. „Emancypancja kobiet", darowany przez ks. J. Wiśniewskiego. Utwór ten opublikował K. W y ka. Marcholt T. 1: 1934/1935 s. $305-319$.

14 Zgodnie z zamierzeniami dołącza się do tego działu rękopisy pozyskane po opracowaniu zbioru, ostatnio np. ,Pamiętnik“ ks. Aleksandra Bastrzykowskiego (1879-1958); por. nekrolog ks. B. w Kron. Diec. sandom. R., 51:1958 s. 250-256.

16 Przy identyfikowaniu kodeksów nie uwzglęaniano argumentów z charakteru pisma.

10 Uwzględnione zostaly przy wyliczeniach druki wszyte do kodeksów ręko-piśmiennych. 
z obcych języków oraz dziela z XIX i XX w., które napisane zostały przez osobistości mniej wybitne i nie przedstawiają wartości naukowej. Układ katalogu abejmuje autorów zgrupowanych zasadniczo według instytucji, w których oni pracowali i według zakonów, do których należeli. Kodeksy zawierające więcej prac rękopiśmiennych zostały zaszeregowane według dziel, przy których stwierdzono nazwisko autora lub miejsce powstania rękopisu. W obrębie poszczególnych grup uwzględniono najpierw przyjęty przez Bibliotekę porządek rzeczowy, tzn. zestawiono dzieła $z$ filozofii, teologii systematycznej, historycznej i praktycznej oraz z literatury i innych przedmiotów. Prace odnoszące się do tego samego przedmiotu ułożono $w$ porządku chronologicznym.

Poszczególne pozycje opisane zostały zasadniczo według Wytycznych opracowania rękopisów $w$ bibliotekach polskich ${ }^{17}$. Dla ułatwienia orientacji wszystkie opisy otrzymały numerację ciągłą. $\mathrm{Na}$ początku opisu podano sygnaturę, pod którą rękopisy są umieszczone w Bibliotece. Tytuły skryptów szkolnych utworzone zostały $z$ napisów oryginalnych i z notatek o wlykładowcach i pisarzach. Opuszczono barokowe tautologie i nic nie wnoszące amplifikacje słowne. Pominięto tytuły przydawane do nazwisk, o ile nie miały one znaczenia jako szczegół biograficzny o danej osobie. Inne określenia uwzględnione zostały $\mathrm{w}$ zasadzie tylko przy cytowaniu autora po raz pierwszy. W miarę możności zebrano informacje biograficzne o osobach występujących w opisach.

\section{A. DUCHOWIENSTWO DIECEZJALNE I AUTORZY SWIECCY}

a) IRAKÓW - AKADEMIA I JEJ SZKOEY

\section{$\mathrm{Nr} 1$}

726. Łac. 1621-1626. $20 \times 17 \mathrm{~cm}$. K. 476. Pismo dwóch rak. Opr. pap. wspt.

Skrypty z wykładów fillozofii.

1. k. 1-72. „In Dialecticae [libros] Aristotelis commentarı Jacobi Gors c i i " 18 .

2. k. 74-99. „Dialectica Stephani $\mathrm{M}$ i c a $\mathrm{n} \mathrm{i}{ }^{19}$ [...] sub Andrea D l ugoleczky artium et philosophiae baccalaureo, anno Domini 1621".

3. k. 100-143. "Tractatio brevis logices".

4. k. 147-190. „In librum Porphyrii seu veteris praeparatio artis [...] sub Nicolao W y so cky per me Sebastianum Pleszczyńsky Radom. 1626 in lectorio Platonis".

17 Wydało Ministerstwo Kultury i Sztuki, Centralny Zarząd Bibliotek, Wroclaw 1955 .

18 Ży w latach ok. 1525-1585; por. o nim art. w Pol. stown. biogr. VIII 438-440 (H. Barycz); inne jego dziela wylicza Bibliografia polska K. Estreichera (cyt. dalej: Estr.). T. 17. Kraków 1890 s. 261-262.

10 Est r. XXII $330-331 ;$ H. B a r y c z: Historia Uniwersytetu Jagiellonskiego W epoce humanizmu. Kraków 1935 s. 418. 
5. k. 194-274. „Praecepta Priorum analiticorum Aristotelis sub magistro et professore Mathia Ewaśniewicz per Sebastianum PleSzczyński Rad. $1626^{\prime \prime}$.

6. k. 275-304. "In libros Posteriorum analiticorum Aristotelis. 1622".

7. k. 314-360. "Praecepta rhetorices".

8. k. 363-373. "Compendium figurarum Jacobi Gorscii sub Sigismundo Grygorow icz [Gregorowicz] ${ }^{20}$ artium et philosophiae magistro $1621^{\prime \prime}$.

9. k. 380-412. „In librum Rhetoricorum ad Caium Herennium [PsseudoCiceronis]".

10. k. 417-451. "In Phisices Jacobi C a r p e n t a r i i Claromontani ${ }^{21}$ libros".

11. k. 453-470. "Computus ecclesiasticus". czyste.

K. 73, 144-146, 191-193, 305-313, 361-362, 374-379, 413-416, 452, 471-476 -

Na k. 1 zapiska tą samą ręką: „Ex cathalogo librorum Sebastiani Płescy[ński] Radomscensis stud. Acad. Crac."

$\mathrm{Nr} 2$

722. Łac. 1636-1647. $19 \times 16 \mathrm{~cm}$, K. 171. Opr. tekt. wspł. zniszcz.

Skrrypty z wykładów.

1. k. $1-32$. „Compendium moralis philosophiae. 17 novembris 1636 ab Luca $\mathrm{P}$ ioh owski [Piotrowski] ${ }^{22}$ artium et philosophiae doctore“.

2. k. 34-134. „Ethica Aristotelis. 5 maii 1647. Albertus P a pe n con i us [Papencovius] Ustiensis ${ }^{23}$, diaconus, ad S. Annam canonicus. Albertus Janicki mpp." 24

3. k. 134v-171. "Ethica Cornelii Valerii. 1637. Christophorus B e r$\mathrm{sz}$ o w ski. Albertus Eascensis".

K. 33 - czysta. Wiele kart uszkodzonych.

$\mathrm{Z}$ biblioteki $\mathrm{w}$ Skrzynnie.

\section{$\mathrm{Nr} 3$}

791. Eac. 1638 r. $20 \times 16 \mathrm{~cm} . K$. 500. Opr. sk. wspt.

Skrypty z wykładów.

1. k. 1-78. "Dialectica Jacobi Gorscii tradita a magistro Alberto Skrzyński, incepta 26 aprilis $1638^{\prime \prime}$.

2. k. 86-500. „Disputationes philosophice“. Zagadnienia z logiki.

K. $79-85$ - czyste.

\section{$\mathrm{Nr} 4$}

723. Eac. $1638-1649.19 \times 15 \mathrm{~cm} . K .351$. Opr. sk. wspt.

Skrypty z wykładów.

1. k. 1-96. "Tractatus quinque Philosophiae naturalis Magni Alberti a me Alberto Eascensi finiti 1638 pridie Idum februarii" (12 lutego).

20 Prepozyt kościoła św. Mikołaja w Krakowie, profesor Akademii; por. o. H. Wy z a s s i OFM: Biskup Piotr Gembicki. Kraków 1957 s. 288-289.

21 E s r. XIV 69; por. ks. A. Us ow icz: Stanislaw Wieczorkowski. Nasza Przeszl. $3: 1947$ s. 147.

22 Profesor Akademii; por. W yczawski, jw. s, 288, 291, 294; Estr. XXIV 304

23 Papenkowic; por. H. Barycz: Metryka promowanych Wydzialu Teologicznego Uniwersytetu Krakowskiego z lat 1639-1741. Nasza Przeszt. $3: 1947$ s. 191.

24 E s t r. XVIII 443. 
2. k. 98-216. „In octo libros Physicorum [...] sub domino [Matthaeo] $\mathrm{Kraśnicki}{ }^{25}$ et Nicolao $\mathrm{Su} \mathrm{lik} \mathrm{O} \mathrm{W} \mathrm{sk} \mathrm{i}^{26} 20$ sept. 1649 finivi. Albertus Janicki mp."

3. k. 217-277. "In quaestiones ex libris IV prioribus“.

4. k. 278-351. "In libros Aristotelis de anima [...] ab Sigismundo Gr y g or ow i c z 1639. Albertus Lascensis studiosus Academiae Cracov."

K. 97 - czysta.

Z biblioteki w Skrzynnie.

\section{$\mathrm{Nr} 5$}

696. Łac. $1639-1647.18 \times 16 \mathrm{~cm} . K .356$. Opr. zniszcz.

Skrypty $\mathrm{z}$ wykładów.

1. k. 1-29. „In libros Thomae $\mathrm{L}$ in a $\mathrm{cr} \mathrm{i}^{27}$ de structura emendata Latini sermonis".

2. k. 35-105. ,In Dialecticam Jacobi Gorscii... sub Sebastiano S e r $\mathrm{g}$ i e $\mathrm{w}$ i $\mathrm{c} z$ in scholis Nowodworscianis professore [...] 1645, per Albertum Janicki descripta $1647^{\prime \prime}$.

3. k. 107-151. "In libros Elenchorum sophisticorum Aristotelis [...] Mathias M a z u k k w i : Albertum Lascensem testor diligentem auditorem $[\ldots]$ m. p." (podpis).

4. k. 155-161. ,In librols Aristotelis Elenchorum exercitia sub Adamo Draski ${ }^{28}$ regio professore 1639 ".

5. k. 162-356. "Cursus philosophiae ad mentem divi Thomae per Albertum Papenkow ic 1646 die 13 maii".

K. 30-34, 106, 152-154-czyste. Wiele kart uszkodzonych.

Z biblioteki w Skrzynnie.

\section{$\operatorname{Nr} 6$}

664. Łac. 1641 r. 18, $5 \times 15 \mathrm{~cm}$. K. 288. Pismo dwóch rqk. Opr. perg. wspl.

Skrypty z wykładów.

1. k. 1-197. "In libros decem Ethicorum Aristotelis [...] traditum per Andream $\mathrm{Ku} \mathrm{ch} \mathrm{ar} \mathrm{s}^{\prime 29} 18$ septembris $1641^{\text {". }}$.

2. k. 198-288. "In octo libros civilis sapientiale Aristotelis".

$\mathrm{Na}$ pergaminie oprawy średniowieczny tekst liturgiczny.

Na k. 1 napis ż XVIII w. „Biblioth. Radomiensis Scholarum Piarum".

$\mathrm{Nr} 7$

672. Łac. $1642-1643.20 \times 17 \mathrm{~cm}$. K. 246. Pismo trzech rqk. Opr. sk. wspt.

Skrypty z wykładów.

1. k. 1-138. „Cursus philosophiae Aristotelico-scholastici traditi in Universitate Cracoviensi“. Logika. Brak kilku ostatnich kart.

2. k. 139-146. Druk: ,Manipulus theorematum logicorum, quem in Alma Academia Cracoviensi [...] sub Jacobi Ustiens is ${ }^{30}$ theol. et

25 Estr. XX $235-236$.

26 Częściej podają rękopisy: Solikowski; por. Barycz: Metryka s. 190; Estr. XXX 25.

27 Por, B a y cz: Historia Uniw, Jagiell, s. 284, 528.

28 Por. o nim art. w Pol. stown. biogr. V 361-362 (H. Barycz); E s tr. XV 304.

28 Por. Barycz: Metryka s. 190; Estr. XX 353.

30 Kustosz kolegiaty św. Floriana w Krakowie; por. Wyczawski, jw. 
i. u. doctoris ac professoris, custodis S. Floriani et c. Studii Cracoviensis Generalis rectoris auspicit's Fr. Prosper Krilinsski Ord. s. Aug. Canonicorum Regularium Lateranen. conventus Mstoviensis propugnavit [...] assistente sibi M. Luca Piotrowski collega maiore cursus philosophici Vladislaviensis professiore a. D. 1642 die 28 octoibris, Cracoviae in offic. Christophorii Schedelii" 31 .

3. k. 147-246. "Cursus philosophici Aristotelico-scholastici ad subtilis Doctoris Scoti mentem traditi Cracoviae 13 martii 1643 sub Luca Piotrowski“. Metafizyka.

K. 147-244 mają paginację współczesną.

Na odwroc e okładki drukowany: Ex libris Francisci Schwartzemberg-Czerny ${ }^{32}$, scholastici Cracoviensis, praepositi Sandomiriensis".

\section{$\mathrm{Nr} 8$}

751. Łac. 1642-1646. $19 \times 15 \mathrm{~cm}$. K. 486. Pismo wielu rak. Opr. tekt. wspt.

Skrypty z wykładów.

1. k. 1-26. "In IV libros Metheororum Aristotelis".

2. k. 1-27. „In libros Aristotelis de generatione et corruptione. Matthaeus Krasśnicki. 1646".

3. k. 1-58. "In XII libros Aristotelis Metaphisicorum. Stanislaus Tem ber ski ${ }^{33}$. $1646^{\prime \prime}$.

4. k. 1-62. „In libros Aristotelis de Republica. Martinus R a d z i$\mathrm{mińs} \mathrm{ki}{ }^{34}$. 1646".

5. k. 1-117. "In Ethicam Aristotelis. Albertus Da m b rows k i ${ }^{35}$ ".

6. k. 1-17. „In libros Topicorum. Matthias z y ś i e w i c ${ }^{36}$ doctor philosophiae. $1645^{\prime \prime}$.

7. k. 1-79. „De peccato originali distinctiones sub Sigismundo Gregorowicz, canonico s. Flcriani, plebano Pajenecensi. 1645".

8. k. 1-3. "In naturas et vires simplicium plantarum et herbarum indigenarum sub $\mathrm{N}$ [icolao $\mathrm{O} \mathrm{ch}$ o $\mathrm{cki} \mathrm{i}^{37}$ med. professore. $1645^{\prime \prime}$.

9. k. 1--8. „In libros Aristotel is de arte rhetorica ad Theodocten sub Nicolao Sulikowski, artium et philosophiae doctiore, eloquentiae ordinario professione. 1642 ".

10. k. 1-23. "In octo libros Phisicorum [...] fínis deest cursus in via Scoti traditi per Lucam Piotrowski professorem. 1642".

11. k. 1-66. „Dispositiones sive exercitium rhetoricum sub Nicolaio

s. 190, 197, 258, 288; B a ry c z: Metryka s. 189; t e nże : Historia Uniw. Jagiell. s. 548; A: Jocher: Obraz bibliograf.-histor. literatury i nauk w Polsce od wprowadzenia do niej druku po rok 1830 włącznie. T. 2 . Wilno 1840 s. 320 nr 3946 (cyt. Jocher).

31 Es tr. XX 264.

32 Por. przyp. 6.

33 Ży w latach ok. 1620-1679; W iśniewski, jw. s. 297; Podręczna encyklopedia kościelna pod redakcją ks. Z. Chelmickiego. T. $39 / 40$ s. $84-85$ (cvt. Enc. Chelm.); Encyklopedia kościelna wyd, przez ks. M. Nowodworskiego. T. 28 s. $283-285$ (cyt. Enc. Now.); J o c h e r II 416, 452 nr $4816,5287$.

. 34 Zył w latach 1610-1664; B a r y c z: Historia Uniw. Jagiell. s. 482, 499, 681, $682,687,730$; Enc. Chelm. T. 33/34 s. 140 .

35 B a rycz: Metryka s. 190; Estr. XV 2.

36 W y czawski, jw. s. 294.

8. Es tr. XXIII 245. 
Solikowski, Stanislao J u r kow s k i ${ }^{38}$ 1644, Andrea Li p n i c i o ${ }^{39} 1644$, Joanne Rachtamovio Cin erski 40 ".

Foliacja wspólczesna.

\section{$\mathrm{Nr} 9$}

690. Eac., pol. 1668-1670. $18 \times 16 \mathrm{~cm}$. K. 557. Pismo dwóch rqk. Opr. tekt. wspl. zniszcz.

Skrypty z wykładów.

1. k. 1-210. „Phisica inchoata sub P. Stanislaio Z y g m u n to w i c z, phil. d[octore], preaposito Myslovecensi, continuata sub Paulo Wojewó $\mathrm{dzki}^{41}$ per me Stanislaum Casimirum Sadowski“.

2. k. $211-313$. „Politicorum Aristotelis libri octo per Sebastianum Ta ra 1 i c [Taralicz] 42. 1668. Stanislai Casimiri Sadowski",

3. $\mathrm{k} 314-438$. "Ethicorum Aristotelis libri decem, quos tradidit Basilius $O 1$ s $z$ y ńs $k \mathrm{i}^{43} 22$ octobris $16.68-13$ nov. 1669. Stanislaus $\mathrm{Ca}$ simirus Sadowski“.

4. k. 439-490. „Optimum genus oratorum in Academia Cracoviensi propositum 29 aprilis 1670. Dictavit Paulus Wojewódzki me scribente Stanislao Casimiro Sadrowski m. p."

5. k. 491-532. „Compendium sphaerae Joannis de Sacro B os co ${ }^{446 .}$ Geometria i arytmetyka.

6. k. 533-548, „Computus ecclesiasticus".

7. k. 549-557. ,In arithmeticam communem seu speculativam Joannis de $\mathrm{M} \mathrm{u}$ r is Parisiensis".

Brak początkowych i końcowych kart.

$\mathrm{Z}$ biblioteki w Skrzynnie.

$$
\text { Nr } 10
$$

790. Łac. 1684 r. $20 \times 16 \mathrm{~cm} . K, 124$. Opr. tekt. wspt.

Skrypty z wykładów.

„Compendium dialecticae $[\ldots]$ in biennio philosophico. Bonaventura Legucki“"

Podpis: "Ex libris Michaelis Legucki m. p.".

$\mathrm{Z}$ biblioteki „Congr[egationis] Orat[orianae] Studziannae“.

$\mathrm{Nr} 11$

704. Łac. 2 pot. XVII w. $31 \times 19 \mathrm{~cm}$. S. 344. Opr. tekt. wspt.

Skrypty z wykładów.

1. s. 1-293. „Cursus philosophicus, logica, phisica et metaphisica [...]

in Jagellonicio archylycaeo biennio pertractandus".

2. s. 293-344. „Phisica menti divi Thomae accomodata“.

Paginacja wspólczesna.

: Prepozyt kolegialy św. Floriana, profesor i relktor Akademii; W y c z a w s k i, jw. s. 288-290; Bary cz: Metryka s. 189; Enc. Chełm. T. 19/20 s. 156; J o c h e r II $272-273$ nr $3461-3462$.

39 Wyczawski, jw. s. 288, 291, 294; Es tr. XXI 308 .

40 Por. o nim w Pol. slown. biogr. IV 124-125 (H. Barycz); Estr. XIV 484.

41 B a r.y c z: Metrylka s. 193, 195; Enc. Chelm. T. $41 / 42$ s. 399.

42 B a ry c z: Metryika s. 193 .

43 Tamże s. 193; Estr. XXIII 349

44 Enc. Chełm. T. $5 / 6$ s. 78. 
Nr 12

741. Eac. 1704 r. $19 \times 17 \mathrm{~cm}$. S. 253. Opr. tekt. wspt. zniszcz.

Skrypty z wykładów.

1. s. 1-69. „Brevis explicatio dialecticae iuxta mentem Thomae Aq. Inchoavit fr. Albertus Nantius sub ... professore suo".

2. s. 1-164. „De logica rationali. Finitum sub Theofilo B r o n ... professore phil. 1704 die 14 julii“.

Na s. 253 notatka współczesna: „Correxit hunc librum Joannes Starzechowski primus censor librorum mpp.".

Paginacja wspólczesna.

Wiele początkowych kart uszkodzonych.

$$
\mathrm{Nr} 13
$$

661. Łac. 1724 r. $32 \times 22 \mathrm{~cm} . S . X, 1137$. Opr. tekt. wspt.

„Philosophia Aristotelico-Thomistica a Gregorio Fili pow ski 45 philos. dre, Vladislaviano et linguarum exoticarum professore, collegiatae s. Annae canonico, parochialis in Pobiedi curato cursu biennali expedita, a. me vero Antonio Wojciechowski auditore observata 1724 die 6 iunii".

$\mathrm{Na}$ s. I-X ,Index dispositionum“. Na s. 1137 spis słuchaczy.

Paginacja współczesna, odrębna dla każdego traktatu.

\section{$\mathrm{Nr} 14$}

1497. Łac., pol. 1751-1761. $19 \times 16 \mathrm{~cm}$ i mniej. S. 488. Pismo wielu rake. Opr. tekt. wspt.

Różne rozprawy i materiały historyczne.

1. s. 1-152. Druk: "Ius capituli seu tractatus novus et absolutus de potestate capituli sede episcopali vacante. Nicolai $\mathrm{Z}$ al as $\mathbf{z} 0 \mathrm{w} \mathbf{s} \mathrm{i}$, Posnaniae 1706". Druk. Akad.46 Brak karty tytuł.

2. s. 153-197. „Axiomata iuris canonici declarationibus amplissimis illustrata seu regulae iuris pontificii“.

3. s. 198-205. "Miscellanea albo różnej materii rytmy".

4. s. 206-252. „Medium ad alias scientias seu dialectica Joannis $\mathrm{C}$ a e s a ri i ${ }^{47}$ Nowodworscianis cultoribus tradita".

5. s. 252-306. "Tractatus de terminis philosophicis“.

6. s. 307-343. Druk: „Złote jarzmo małżeńskie“. Brak karty tytuł.

7. s. 345-374. Druk: „Krótkie zebranie praw, przywilejów, wolności, swobód, prorogatyw [...] miastu [...] Kralsowowi [...] nadanych, r. 1754, J[akub] Tobolski" ${ }^{48}$.

8. s. 375-384. Druk: „Protestatio contra patres Societatis Jesu collegii Leopoliensis feria II post dominicam Judica Quadrages. 1.760"49. W sprawie uniwersytetu Jana Kazimierza.

9. s. 385-402. Druk Stanisława Duńczewskiego: „Nowa sława collegium warszawskiego Societatis Jesu przez matematyka Zamojskiego wzajemnie obroniona r. 1761" 50.

45 B a r y cz: Metryka s, 200, 205.

46 Estr. XXXIV 119-126; J. F. v. Schulte: Die Geschichte der Quellen und Literatur des canonischen Rechts. Bd 3/1. Graz 1956 s. 772.

47 B a r y c z : Historia Uniw. Jagiell. s. 62, 283, 285, 365; E s t r. XIV $4-6$.

48 Es t r. IX 263, XXXI 183.

49 Es t r. XXV 315.

50 Estr. XV 403; por. o Stanisławie Dunczewskim art. w Pol. slown. biogr. VI $4-5$ (A. Birkenmajer). 
10. s. 403-440. Druk: „Uwiadomienie o konwikcie poznańskim […] r. 1756 dnia 30 lipca. Z druk. Collegium Poznańskiego Soc. J.51 “

11. s. 441-454. Spis wydarzeń historycznych ze starożytności według kalendarza.

12. s. 455-488. „Fasciculus sententiarum ad commune colloquium...“ Wiersze i wzory przemówień łacińskich.

$$
\text { Nr } 15
$$

744. Pol. 1818 r. $21 \times 14 \mathrm{~cm}$. K. 540. Zeszytów 45.

Skrypty z wykładów.

1. k. $1-180$. "Historia filozofii. Kurowski J."

2. k. 181-421. Logika przez [Józefa Emanuela] J a n k o w s k i e g o ${ }^{52}$ w Akademii Krakowskiej 1818 dawana".

3. k. 422-540. „Filozofia praktyczna“"

$$
\text { Nr } 16
$$

562. Łac. 1639 r. $20 \times 16 \mathrm{~cm}$. S. 606. Opr. perg. wspt.

Skrypty z wykładów teologii dogmatycznej.

1. s. 1-210. „Tractatus de Sanctissima et Individua Trinitate [...] sub Adlamo O p at o vio ${ }^{53}$ s. theol. doct. 23 maii $1639-14$ sept. 1639".

2. s. $211-606$. „Tractatus de angelis. 1639“.

Kodeks uszkodzony. Paginacja wspólczesna.

$\mathrm{Z}$ biblioteki' w Skrzynnie.

Nr 17

548. Eac. 1640-1641. $20 \times 17 \mathrm{~cm}$. S. 682. Opr. sk. wspt. Skrypty z wykładów.

1. s. 1-213. „Tractatus de gratia Dei sub professore Jacobo Ustiensi“.

2. s. 215-468. „Tractatus de fidei christianae natura sub professore Jacobo Ustiensi iuris utriusque doctore, canonico s. Floriani, plebano Corcinensi, Cracoviae 12 octrobris $1640^{\prime \prime}$.

3. s. 469-682. „Tractatus controversiarum cum hereticis sub Jacobo Ustiensi s. theol. doctore et professore. 6 sept. 1640 - 23 febr. 1641".

Paginacja współczesna.

$$
\mathrm{Nr} 18
$$

514. Łac. 1642-1649. $20 \times 17 \mathrm{~cm}$. K. 258. Opr. zniszcz.

Skrypty z wykładów.

1. k. 1-40. ,Tractatus de natura theologiae et attributis divinis per Stanislaum Jurkowski s. theol. doctorem Romanum in Alma Academia Crlacoviensi 3 sept. 1648 - 12 martii 1649. Albertus Janicki“".

2. k. 45-88. "In librum II Magistri Sententiarum de creatione finitum ab Adamo Draski ecclesiae s. Floriani decano nec non scholarum Nowodworscian'arum provisore 23 martii 1648 . Functus est a vita sua die 4 decembris 1648 . Albertus Janicki".

3. k. 89-116. „In S. D. Angelici de peceato originali tractatum ab Adamo Draski professore 22 sept. 1648. Albertus Janicki“.

51 Estr. nie notuje tego druku.

52 Zmarl w 1847 r.; Enc. Chelm. T. 15/16 s. 386; Es t r. II 199.

53 Ks. F. B r a ch a CM: Adam Opatowski (1574-1647). Nasza Przeszt. $3: 1947$ s. 121-144; Enc. Chelm. T. 29/30 s. 212; Est r. XXIII 367-371; J och er II 311, $344 \mathrm{nr} 3866$, 4160, III 21, 119, 432, 434, $435 \mathrm{nr} 5740,6738,8407,8431,8432,8442$. 
4. k. 117-130. „De perfectione angelorum sub Jacobo Viteli o ${ }^{54}$ 22 sept. $1642^{\prime \prime}$.

5. k. 132-144. "In tractatum de praedestinatione".

7. k. 187-221. "Tractatus de spe sub Andrea Kucharski s. theol. bac-

6. k. 146-183. „Disputatio de fide sub Adamo Draski finita 19 sept. calaureo, cononico s. Floriani finitus 18 sept. 1648. Albertus Janicki mpp."

8. k. 222-258. „In tractatum de iure et iustitia ex secunda secundae divi Thomae per Andream Kucharski s. th. baccalaureum, canonicum s. Floriani, thesauri Regni custodem incepta ... octobris 1648, finita 3 martii 1649. Albertus Janicki“.

K. 41-44, 131, 145, 184-186 - czyste.

Kodeks podniszczony.

$\mathrm{Z}$ biblioteki w Skrzynnie.

\section{Nr 19}

543. Eac. 1688-1690. $19 \times 15$ cm. K. 418 Opr. tekt. zniszcz.

Skrypt $\mathrm{z}$ wykładów.

„Cursus theologicus ad mentem s. Thomae Aq. Tradidit 19 sept. 1690 [Casimirus] Venceslaus Straszyński ${ }^{35}$ “. Całość dogmatyki.

$\mathrm{Nr} 20$

622. Eac. $1648-1650.19 \times 15,5 \mathrm{~cm}$. K. 403. Opr. zniszcz.

Skrypty $\mathrm{z}$ wykładów teologii moralnej.

1. k. 1-32. „Tractatus de Decalogo seu decem praeceptis“. Nie dokończony.

2. k. 38-75. "In tractatum casuum conscientiae".

3. k. 76-106. "In tractatum de poenitentia, 1 martii 1649 in collegio iurisperitorum Cracoviae".

4. k. 107-117. „In tractatum de restitutione, quae a Laurentio $\mathrm{Ka-}$ $\mathrm{ryn} s \mathrm{ki} \mathrm{i}^{56}$ iuris utriusque doctore et professore dicta sunt, incepta 4 novembris 1648, finita 15 martii 1649. Albertus Janicki mpp.“

5. k. 118-145. „In tractatum de Eucharistiae Sacramento, finita a Laurentio Karyński, IUD, in Academia Cracoviensi professore 1649 Albertus Janicki mpp."

6. k. 146-184. „In tractatum de censuris per Laurentium Karyński finita Cracoviae 8 april. 1650, post obtentum ordinem diaconatus Albertus Janicki mpp."

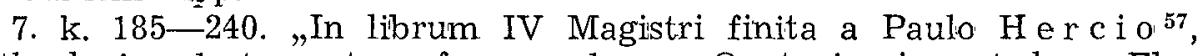
s. theologiae doctore et professore, decano Opatoviensi, custode s. Floriani ad Cracoviam, canonico Kurzeloviensi, plebano Grocholicensi 30 martii 1648. Albertus Janicki mpp."

8. k. 245-403. „Disputatio IV de effectibus baptismi, in tractatum de sacramento confirmationis, Eucharistiae, sponsalibus et matrimonio

54 Barycz; Metryka s. 189 ; W y c z aw ski, jw. s. 67-68; Enc. Chelm. T. $41 / 42$ s. $67 ; \mathrm{J}$ ocher III $434 \mathrm{nr} 8430$.

55 Por. Bary c z: Metryka s. 193; Estr. XXIX 324.

56 Kanonik kościoła Wszystkich Swiętych w Krakowie; Wyczawski, jw.

s. 244, 291, 294; E s t r. XIX 165.

57 B a ry c z: Metryka s. 189; E s t r. XVIII 135. 
a Dionisio Politowi cz ${ }^{58}$, artium et philosophiae doctore, in collegio iurisperitorum professore. 26 martii 1648. Albertus Janicki“.

K. $33-37,241-244-$ czyste.

$\mathrm{Z}$ biblioteki w Skrzynnie.

\section{$\mathrm{Nr} 21$}

630. Łac. 1723-1725. $20 \times 15,5 \mathrm{~cm}$. K. 338. Opr. tekt. wspt.

Skrypt z wykładów.

„In theologiam moralem praefatio, tractatus de sacramento ordinis, Eucharistiae et sacrificio Missae, de praeceptis Dei et Ecclesiae. Hoc opus theologiae moralis traditum est in Universitate Cracoviensi a Joanne $\mathrm{Lu} \mathrm{k}$ in i ${ }^{59}$, iuris utriusque doctore, praeposito Slawkovicensi, Vislicensi, primicerio studii Universitatis rectore, scriptum per me Cantium $\mathrm{Mi}$ kowski in eadem Universitate baccalaureo, per biennium traditum ab anno 1723 ad 15 martii 1725 “.

Na k. 1 notatka: „Biblioth. domus Radomiensis Scholarum Piarum anno 1743 accepit ex procuratione P. Nicolai a S. Antonio".

$\operatorname{Nr} 22$

1824. Pol. 1953 r. $29,5 \times 21 \mathrm{~cm}$. K. 181. Masz. Opr. ptplt.

Ks. mgr Jan B udzińs' $\mathrm{ki}^{60}$ : ,Stan religijno-moralny Dekanatu Szydłowieckiego w latach 1939-1949. Praca doktorska napisana pod kierunkiem ks. Władysława Wichra profesora Uniwersytetu Jagiellońskiego w Krakowie. 1953".

Dar autora.

$\mathrm{Nr} 23$

329. Łac. 1800-1801. $19 \times 12 \mathrm{~cm}$. K. 144. Opr. tekt. wspz.

Skrypt $\mathrm{z}$ wykładów biblistyki.

"Prolegomena in S. Scripturam authore Ferdinando K o pf, Cracoviae 1800. Joannis Zawisz[a] m. p. alumni Seminarii Arcensis 6 iunii $1801^{\prime \prime}$.

Na k. 1 podpis: „P. Maurus Kucępa mp.“

\section{$\mathrm{Nr} 24$}

1511. Łac. 1639-1642. $22 \times 15 \mathrm{~cm}$. K. 606. Opr. perg. wspt.

Skrypty z wykładów prawa kanonicznego.

1. k. 1-75. „De personis libri quatuor, sub Laurentio Karyński collega iurisconsultorum Academiae Cracoviensis. 12 sept. 1641".

2. k. 76-143. „Regulae iuris libri VI Decretalium, sub Stanislao $\mathrm{Czaplic}{ }^{61}$ seniore centubernii iuristarum reformationis Garvascianae iuris utriusque baccalaureo finitum 5 martii $1639^{\text {". }}$

3. k 144-170. „Flores legum ex variis legibus, glossis et doctoribus collecti“. Układ alfabetyczny od A do V.

4. k. 171-286. "In IV Institutiorum iuris canonici libros, sub Stanislao Czaplic finitum 12 sept. $1641^{\prime \prime}$.

5. k. 289-321. "Processus iudiciarii compendium".

58 W y c z a s k i, jw. s. 288, 291, 294; Es tr. XXIV 450.

59 B ary c z: Metryka s. 207; Estr. XXI 522.

60 Por. [ks. St. Le gię ć] Ks. St. L.: Sp. ks. Jan Budziński. Kron. Diec. sandom. R. $52: 1959$ s. $63-64$.

61 Por. o nim. art. w Pol. słown. biogr. IV 172 (H. Barycz); E s t r. XIV 512. 
6. k. $322-381$. „In V librum Decretalium de accusationibus, inquisitionibus et denuntiationibus rubrica, diligentia magistri Stanislai Czaplic iuris utriusque doctoris, contubernii iurisperitorum senioris 13 sept. 1640 ".

7. 382-402. „De mitigandis poenis reorum sanguinis vel tollendis, labore Jacobi $\mathrm{N}$ a y man $\mathrm{OW} \mathrm{Cz}^{62}$, iuris utriusque doctoris, canonici ecclesiae cathedralis Cracoviensis, archidiaconi Pilecensis, decani collegii iurisperitorum, in Alma Academia Cracoviensi praesidentis. 7 sept. $1640^{\prime \prime}$.

8. k. 403-453. „Tractatus de fide instrumentorum, authore Jacobo Naymanowicz, iuridicae facultatis decario, finitus 8 martii 1640 ".

9. k. 455-476. „Selectiores in contractu venditionis et emptionis difficultates".

10. k. 478-540. "Tractatus de rebus Ecclesiae alienandis vel non, Joanne $R$ óż y k i ${ }^{63}$, IUD, collega iurisperitorum in Alma Academia Cracoviensi huic operi finem imponente 14 martii 1642, manus applicatae per me Felicianum Wąsowicz".

11. k. 541-553. „Rubrica de sponsalibus et matrimonio. Adamus Rozczewic ${ }^{64}$, IUD et professor, per Felicianum Wąsowicz auditorem scriptum m. p."

12. k. 554-574. „Processus iudiciarius. Adamus Rozczewic, IUD et professor, collega iurisconsultorum ita esse testatur mp."

13. k. 576-595. „Rubrica de sponsalibus et matrimonio. Adamus Rozczewic - Felicianum Wąsowic testor diligentem et assiduum auditorem fuisse m. p."

14. k. 596-606. „Modus legendi abbreviaturas in utroque iure occurrentes. Adamus Rozczewic - diligentem et assiduum auditorem Felicianum Wąssowic testor fuisse m. p."

K. 287-288, 454, 477, 575 - czyste.

Początkowe karty zniszczone.

$\mathrm{Z}$ biblioteki klasztoru dominikanów w Klimontowie.

$\mathrm{Nr} 25$

1481. Łac. 1648 r. $19 \times 15,5 \mathrm{~cm}$. K. 369. Opr. zniszcz.

Skrypty z wykładów.

1. k. 1-19. "Tractatus de contractibus per Jacobum Górski ${ }^{65}$ in collegio iurisperiforum 10 sept. 1648“.

2. k. 23-51. "Tractatus de sententia et re iudicata".

3. k. 52-147. "Institutiones iuris canonici".

4. k. 150-183. "In Apocalipsam praenotiones".

5. k. 184-238. "In tractatum de gratia Dei disputationes".

6. k. 244-297. "In epistolam s. Pauli ad Romanos".

7. k. 298-369. "In epistolam s. Pauli I ad Corinthios".

62 Źył w latach 1580-1641; B a ry c z: Historia Uniw. Jagiell. s. 591; Enc. Chełm. T. 27/28 s. 289; Enc. Now. XV 394-395; K. M e c he rzy ńs k i: Historia wymowy w Polsce. T. 3. Kraków 1860 s. 260; E s t r. XXIlI 21.

e3 Zyl w 1. 1603-1679; Enc. Chelm. T. $33 / 34$ s. $384-349$; Enc. Now. XXXV 551; Estr. XXV 433.

64 Zmarl w r. 1669; W y c z a w sk i, jw. s. 213, 244, 288; E s tr. XXVI 362.

65 Zyl w 1. 1585-1652, prof. i rektor Akademii Krak., kanonik kap. katedr. krak.; Jocher III $286 \mathrm{nr}$ 7312. Por. o nim art. w Pol stown. biogr. VIII 440-441 (L. Hajdukiewicz). 
K. 20-22, 148-149, 239-243 - czyste.

$\mathrm{Z}$ biblioteki w Skrzynnie.

Nrr 26

1501. Eac. 1688-1689. 18,5×16. K. 319. Opr. zniszcz.

Skrypty z wykładów.

1. k. 1-132. "Tractaitus in praecepta Decalogi“. Brak początku i końca.

2. k. 141-250. "Institurtiones iuris canonici in Academia Cracoviensi a magistro Zacharia Thesznarowicz explanatae et per Paulum Bargiel Silesium Sorensem exceptae commutatione aestiva 1688-1689".

3. k. 254-319. „Explicatio regularum utrique iuri communium a Zacharia Thesznarowicz, protonotario apostolico, Sanctorum Omnium Cracoviae canonico et iuris utriusque licentiato et contubernii iuridici seniore, per Paulum Bargiel 1688-1689".

K. 133-140, 251-253 - czyste.

$\mathrm{Nr} 27$

363. Łac. 1659-1660. 18,5×15 cm. K. 84. Opr. tekt. zniszcz.

Skrypty $z$ wykładów wymowy.

1. k. 1-63. ,Liber rethorices traditus ab Joanne $R$ udzki ${ }^{66}$ professore, scriptus per Stanislaum Szeligowslei commutatione hiemali $1659^{\prime \prime}$.

2. k. 64-84. "Compendium dialecticae decerptum a Stanislaro Szeligowski $1660^{\prime \prime}$.

Na k. 1 podpisy: Joannes Szeligowski. "Congregatio Orat. Studziannae“.

$\mathrm{Nr}^{*} 28$

354. Łac. 1659-1660. 19,5×18,0 cm. K. 78. Opr. sk. wspl.

Skrypty z wykładów.

1. k. 1-33. „Liber dispositionum traditus a Joanne Rudzki, scriptus per alumnum eiusdem Gymnasii Stanislaum Szeligowski, situdiasum rhetorices anno 1659-1660 commutatione hiberna".

2. k. 34-78. "Liber dispositionum decerptarum per Andream A l e$\mathrm{x}$ a $\mathrm{nd} \mathrm{rowicz}$, professorem, dialectices commutatione aestiva 1660 . Stanislaus Szeligowski“.

$\mathrm{Na}$ k. 1 napis: „Congr. Orat. Studziannae“.

\section{$\operatorname{Nr} 29$}

442. Pol., tac. 1736 r. $20 \times 17 \mathrm{~cm}$. K. 130. K. Opr. tekt. wspt. zniszcz. "Contiones pro quolibet festo collectae, in anno 1736 inchoatae 6 aprilis manu propria Mathiae Spolczynski auditoris scholae philosophiae".

Dar ks. Stanisława Resztaka z biblioteki kanoników regularnych w Bogorii.

$$
\text { N.r } 30
$$

1813. Eac., pol. 1637-1639. $19,5 \times 16 \mathrm{~cm}$. S. I, 434, w tym nie zapis. Pismo dwu rakk. Opr. deska w sk. wspt. zniszcz.

Skrypty z wykładów i maiteriały.

1. s. 1-96. „Explicatio cathechismi catholici sub Balthasaro Stanislao Przyłuski, artium magistro, philosophiae doctore, in collegio

lifi Estr. XXVI $476-477$. 
Białensis Academiae ordinario eloquentilae professore. Paulus Sczebietowicz, publicarum lectionum auditor in lectorio rhetorices Białae 1637 mppa."

2. s. 1-54. „Computus annorum et temporum. 1637 die 4 sept. in lectorio rhetorices Białae sub domino Przyłuski scribere coepi, Paulus Sczebietowicz mppa."

3. s. $1-210$. "Logica. 8 octobr. 1638-1639 Albertus Axonius Białae legere aggressus est. Idem, qui supra mppa." $\mathrm{Na}$ s. 210 lista słuchaczy.

4. s. 1-16. „Actio ad s. Sepulcrum die Parasceves habita“. Polskie misterium pasyjne $\mathrm{w} 3$ aktach.

5. s. $1-2$. "In philosiophiam naturalem praefatio".

6. s. 1-14. "Propirietates variarum gentium".

7. s. $1-42$. "Litterae passus. Scribere coepi 2 ianuarii 1639 Białae". Wzory listów. Na s. 18-24 "Laureatio et nobilitatio Joannis Dantisci“. $\mathrm{Na}$ s. 24-42 "Intentio Christophori Wilscii fundatoris Academiae Białensis, ex actis consistorii Janoviensis deprompta". Dekret biskupa luckiego Andrzeja Gembickiego aprobujący erekcję. Brak końca.

Paginacja współczesna.

Na s. 1: „Ex libris Congregationis Oratorii Studziannensis”.

Nr 31

1736. Eac. 1659 r. $17 \times 16 \mathrm{~cm}$. S. 154. Opr. zniszcz.

Franciscus Vincentius Tomecki: ,Novitas praecipuarum Polaniarorum gratissima, iuventuti in Academia Cracoviensi alphabetico ordine explicata, calamo Joannis" Zarczyński connotata". Hasła encyklopedyczne od A do M.

Nr 32

1704. Eac. 1726 r. $19,5 \times 16,5$ cm. S. 208. Pismo dwóch rąk. Opr. tekt. wspt.

„Campus electorum [...] apertus ad lauream capescendam legatis NeoPoesis Athenei Jagellonici..." Wzory wierszy i' listów.

\section{$\mathrm{Nr} 33$}

1704. Pol. 1785-1786. $38 \times 21,5 \mathrm{~cm}$. S. 82. Opr. brosz.

„Krótkie zebranie minerallogii. Wyjątek z kursu chemii i historii czytanego na posiedzeniu Akademii Krakowskiej przez J[anau J aśki e wic z a ${ }^{66 \mathrm{a}}$ w latach $1785-1786^{\circ "}$.

Dar ks. Jana Wiśniewskiego.

\section{b) LUBLIN - KATOLICKI UNIWERSYTET LUBELSKI}

\section{$\mathrm{Nr} 34$}

571. Pol. 1927 r. $28 \times 22 \mathrm{~cm}$. K. 119. Masz. Opr. ptt.

Ks. lic. Franciszek B ob íński67: „Dar bojaźni Bożej. Rozprawa doktorska. Lublin, maj 1927“.

${ }_{66}^{66}$ Żyl W l. 1748-1809. Estr. XVIII 504.

${ }^{67}$ Ży $W$ 1. 1897-1946; Lista absolwentów w Archiwum Seminarium Duch. w Sandomierzu $\mathrm{nr} 861$. 


\section{c) PETERSBURG - AKADEMIA DUCHOWNA}

\section{Nr 35}

781. Łac. 1917 r. $35 \times 21,5 \mathrm{~cm}$. S. 295. Opr. brosz.

Josephi Gołuchowski doctrinae de religione expositio et valor. Dissertatio philosophica, quam pro gradu s. theologiae magistri obtinendo conscripsit Thaddaeus Julianus Ja chimows $\mathrm{ki}$, s. theol. candidatus, presbiter dioecesis Kielcensis, Petropoli 1917".

$\mathrm{Z}$ księgozbioru ks. Adama Szymańskiego ${ }^{68}$ b. profesora Akademii Duchownej.

Nr. 36

336. Łac. 1901 r. $21 \times 15 \mathrm{~cm}$. S. 58. Zeszyt.

Ks. Pa'weł $\mathrm{Ku}$ bi c k i ${ }^{69}$ : „De cabbalistica interpretationis methodo". Brulion rozprawy $\mathrm{w}$ celu uzyskania stopnia kandydata teologii $\mathrm{w}$ Akademii Duchiwnej.

Dar autora.

\section{$\mathrm{Nr} 37$}

1472. Pol., łac., ros. 1897 r. $36,5 \times 22,5 \mathrm{~cm}$. K. 38 . Opr. brosz.

Józef R okoszny ${ }^{70}$ : „De beatificatione et canonizatione Sanctorum“. Brulion rozprawy magisterskiej; Petersburg, 18 kwietnia 1897 r.

\section{d) SANDOMIERZ - SEMINARIUM DUCHOWNE}

\section{$\mathrm{Nr} 38$}

777. Pol. 1823 r. $22,5 \times 18 \mathrm{~cm}$. S. 140 . Opr. tekt.

Ks. [Karol] T e lig a ${ }^{71}$ : „Metafizyka“. Podręcznik.

\section{$\mathrm{Nr} 39$}

1740. Eac. 1 pot. XIX w. $20 \times 17 \mathrm{~cm}$. K. 219. Opr. tekt.

Skrypty z wykładów.

1. k. 1-140. "Physica generalis". 7 tablic z rysunkami.

2. k. 141-219. "Physica particularis. Scripsit Adalbertus Okoński propter Maurum $\mathrm{K}$ u c z ę $\mathrm{p} \mathrm{a}^{72}$, professorem philosophiae".

$\mathrm{Na}$ ostatnich $3 \mathrm{k}$. rysunki z fizyki i kosmologii.

${ }^{68} \mathrm{~W}$ iśniew ski, jw. s. 293; [ks. S. Kotow ski] Ks. S. K.: Sp. ks. prał. Adam Szymański. Kron. Diec. sandom. R. 49: 1956 s. 78-80.

69 Wiśni e wski, jw. s. $169-172$.

70 Tamże s. 254-259.

71 Enc. Chelm. T. $39 / 40$ s. 84; Enc. Now. XXVIII 281-282; Ks. M. B u lińs k i: Monografia miasta Sandomierza. Warszawa 1879 s. 406 uw. 1. Biblioteka posiada również inne rękopisy tego autora: "Filozofia, część III - fizyka i astronomia", "Theologia dogmatica breviter exposita“, „Theologia dogmatica in usum alumnorum Seminarii Sandomiriensis“, „Institutionum Chaldaeicarum synopsis“, „Institutiones hermeneuticae generalis. Praeliminaria“, "Introductio in libros Veteris Foederis in usum alumnorum Seminarii Sandomiriensis", „Rozbiór pieśni Mojżesza", „Interpretatio exegetica Psalmorum", „Introductio in libros sacros Novi Foederis", "Introductio specialis in libros Novi" Foederis" (sygn. 775, 574, 575, 315, $313,310,337,317,334,316)$. Są to skrypty pisane dla kleryków przed r. 1838.

72 B. cysters, zmarl w 1834 r.; B ul in s k i, jw. s. 408; Ks. J. W is niew ski: Seminarium Duchowne... oraz stuletni katalog duchowieństwa swieckiego diec. sand. Warszawạ 1926 (układ alfabetyczny bez paginacji). 
$\mathrm{Nr} 40$

714. Pol. 1845 r. $22 \times 17 \mathrm{~cm}$. S. 52. Opr. tekt.

Marcin Witkowski: „Historia filozofii według wylkładów Karola G ó rskieg $0^{\prime \prime 73 . ~}$

$\mathrm{Nr} 41$

1394. Pol. 1838-1839. $20 \times 17 \mathrm{~cm}$. S. 533. Opr. tekt.

$\mathrm{X}$. Jan Chryzostom D a b r ow ski ${ }^{74}$ : „Historia Kościoła Polskiego wykłady dla alumnów Seminarium Sandomierskiego".

$\mathrm{Nr} 42$

1015. Pol., łac. 1844 r. $36 \times 23 \mathrm{~cm}$. S. 28. Zeszyt.

Ks. Antoni $\mathrm{M}$ is iórski ${ }^{75}$ : „Opis klasztoru i kościola PP. Benedyktynek Sandomierskich".

$\operatorname{Nr} 43$

1473. Eac. 2 pot. XIX w, 35,5X21,5 cm. K. 19. Opr. brosz.

„Regulae cancellariae in causis matrimonialibus per Ludovicum P i ot r o w i z ${ }^{76}$, professorem iuris canonici Sandomiriae..."

e) SEJNY - SEMINARIUM DUCHOWNE

$\mathrm{Nr} 44$

321. Eac. $1835 r .21 \times 17 \mathrm{~cm}$. K. 44. Zeszyt.

„De Sacra Sriptura. A. Januszewrski. Sejny 1835“.

f) WARSZAWA - UNIWERSYTET I AKADENIA DUCHOWNA

$\operatorname{Nr} 45$

774. Pol. 1830 r. $21 \times 19 \mathrm{~cm}$. S. 616. Opr. tekt.

X. [Rafał] $\mathrm{Skolimow} \mathrm{ski}^{77}$, profesor Uniwersytetu Warsz.: „Filozofia, w szczególe fizyka, chemia, mechanika, algebra, logika, ontologia..." Notatki z wykładów pisane przez Jana Dąbrowskiego.

\section{$\mathrm{Nr} 46$}

708. Pol. 1863 r. $28 \times 22 \mathrm{~cm}$. S. 429. Opr. tekt.

„Logika, poprzedzona wstępem psychologicznym. Odczyt uniwersytecki Doktora Henryka Stru we ${ }^{78}$, profesora Szkoły Głównej w Warszawie".

\section{Nr 47}

607. Eac. 1863 r. $18,5 \times 15 \mathrm{~cm}$. S. 146. Opr. tekt.

73 Buliński, jw. s. 407; Wiśniewski, jw.

74 Zesłaniec za udział w powstaniu 1863 r., zmarł w r. 1887; Bu 1 i ńs k i, jw. s. 407; W iś n ie w s k i, jw.

75' Zył w I. 1813-1885; W i śn i e w s k i: Katalog prałatów s. 206-207.

76 W is n i e w s k i: Katalog prałatów s. 233-235.

77 Zył w 1. 1781-1848; Ks. A. P l e s z c z yńs k i: Dziej.e Akademii Duchownej Rzymskokatolickiej Warszawskiej. Warszawa 1907 s. 144-148; Enc. Now. XXV $483-485$.

78 Enc. Chelm. T. $37 / 38$ s. $167-168 ;$ E str. IV 397. 
Orzeszkowski Vincentius ${ }^{79}$, professor in Academia Ecclesiastica Regia Caesarea Varsaviensi: „Enchiridion selectiorum casuum conscientiae".

Podpis: ks. Tomasz Sokalski ${ }^{80}$.

$\mathrm{Nr} 48$

318. Eac. 1829 r. $21 \times 18 \mathrm{~cm}$. S. 184. Opr. brosz.

L[udovicus] A. Ch i a $\mathrm{r}$ in i $^{81}$ : „Archeologia biblica per discipulum Universitatis Reg. Varsav. Joannem Dąbrowski collecta“.

Skrypt $z$ wykladów.

$\mathrm{Nr} 49$

319. Eac. 1830 r. $22 \times 19 \mathrm{~cm}$. S. 256. Opr. brosz.

"Institutiones hermeneuticae generalis, expositae in Universitate Regia Alexandrina per $\mathrm{P}$ [aulum $\mid \mathrm{S} \mathrm{z}$ y $\mathrm{m}$ a $\mathrm{n} \mathrm{s} \mathrm{ki}$ (22, decanum facultatis theologicae".

Podpis: J[oannes] D[ąbrowski].

$\mathrm{Nr} 50$

804. Pol. 1 pot. XIX w. $21,5 \times 19 \mathrm{~cm}$. S. 174. Opr. brosz.

„Propedeutyka do historii powszechnej w Uniwersytecie KrólewskoAleksandryjskim prrzez Feliksa B e n tk ow s k i e g o ${ }^{83}$ “.

Podpis: ks. A. Jakubowski, ekspijar z Radomia i Blotnicy.

\section{$\mathrm{Nr} 51$}

1299. Eac. 1830 r. $22 \times 18 \mathrm{~cm}$. K. 66. Opr. brosz.

„Manuscriptum historiae Ecclesiae Polonicae ex praelectionibus academicis in Universitatis Regiae Alexandrinae Facultate Theologica per St [!] Sia rkiew ic $z^{84}$, professore historiae ecclesiasticae. Varsaviae".

Podpis: Joannes Dąbrowski.

$\mathrm{Nr} 52$

1825. Pol. 1932 r. $35,5 \times 22,5 \mathrm{~cm}$. K. 116. Masz. Opr. brosz.

Ks. Stanisław K o z ł o w s k i 85 : „Organizacja oficjalatu w Polsce do końca średniowiecza. Rozprawa doktorska. Warszawa, 7 stycznia 1932“.

Dar autora.

g) WILNO - UNIWERSYTET

$\mathrm{Nr} 53$

693. Pol. 1823-1824. $17 \times 11 \mathrm{~cm}$. K. 74. Opr. tekt.

1. k. 1-36. „Rozprawa o cierpieniach w tym życiu, napisana przez Ignacego [!] Golochow s k i e go ${ }^{86}$ r. 1824“. Odpis.

79 P l eszczy ńs k i, jw. s. $128-129$.

80 W i śn i e w s k i: Katalog pralatów s. $275-276$.

81 Por. o nim art. w Pol. slown, biogr. III 290 (M. Manteuffilowa); Enc. Now. III $263 ; \mathrm{Es}$ tr. I 191.

82 Zył w l. 1782-1852; Ples z c y ńs k i, jw. s. 108-110; Enc. Chełm. T. 39/40 s. 24-25; Estr. IV 470 .

83 Por. o nim art. w Pol. stown. biogr. I 440-4442 (S. P. Koczorowski); Estr. I 85 .

84 Chodzi o ks. Jakuba Szarkiewicza; por. P l es z c z y ń s k i, jw. s. 141-142; Es tr. IV 434; żyl on.w latach $1776 \longrightarrow 1846$.

85 Por. ks. F. Ch 1 eb n y: Sp. ks. Stanisław Kozłowski. Kron. Diec, sandom. R. 53: 1960 s. $61-62$. 
2. k. 37-74. „Otwarcie kursu filozofii w Uniwersytecie Wileńskim przez Ignacego Golochowskiego w r. 1823“. Drukowane w Bibliotece Warszawskiej 1842 , t. 2 s. $225-258$.

Podpisy: „Dargohn [?] A. 1827. Königsberg. „Ks. Kuszewski, 18 stycznia 1867. Nowogródek".

\section{h) ZAMOSC - AKADEMIA}

Nr 54

665. Eac. 1772 r. $19,5 \times 16 \mathrm{~cm}$. S. 228 . Opr. tekt.

„Physica ad mentem S. Thomae in Universitate Zamoscensi per Andream Gabrielem K o s tk i ew i c ${ }^{687}$. Skrypt z wykładów.

\section{i) AUTORZY POZASZKOLNI I Z NIEUSTALONYCH SRODOWISK}

Nr 55

251. Łac. XVII-XVIII w. $14-9$ cm. K. 319. Opr. zniszcz.

"Vera manu conscriptum ab Andrea $\mathrm{Br}$ oln $\mathrm{ick} \mathrm{i}^{88}$, canonico et officiali Sandomiriensi" - współcz. notatka inną ręką.

1. k. 1-101. „Exercitili liturgici et eucharistici hebdomas prima. Praeparationis ad sacrum pars prima".

2. k. 102-319. Opisy różnych praktyk ascetycznych.

K. 106-107, 150-166, 2C9, 255, 295-299 - czyste. Na początku i na końcu czyste karty zniszczone.

Na k. 1: „Ex libris Martini Jasiński ${ }^{89}$, C[anonici], P[arochi] Sand[omiriensis].

$\operatorname{Nr} 56$

35. Eac., pol. 1732 r. $14 \times 9 \mathrm{~cm} . S 270$. Opr. sk. wspt.

„Elogia Mariana a [Augustino Casimiro] Redeliło Belg. Mechl. ${ }^{89}$ concepta, nunc inventa et delineata per Thomam $S c h$ effler et aeri incisa a Matrino Engelbrecht ${ }^{90}$, chalcographo Augustano, anno 1732. Litanie lauretańskie w medytacjach ofiarowane". Sztychów 59.

Dar ks. Gabriela Czerwińskiego z Janowca.

\section{$\mathrm{Nr} 57$}

243. Pol. 2 pot. XIX w. $20 \times 16 \mathrm{~cm}$. K. 32. Zeszyt.

„Dwadzieścia cztery żywoty Swiętych Pańskich Paitronów i Patronek z przydaniem krótkich moldlitw, skreślone wierszem przez Marię M alin

86 B. J. G a we ck i: Gołuchowski Wojciech Józef. W: Pol. słown. biogr. VIII 263-264; W. Tata $\mathrm{rki}$ e wic z: Historia filozofii. Wyd. nowe. T. 2. Warszawa 1958 s. $321-322$.

87 Estr. XX 154.

88 Zmarł w r. 1706; W iśn ie w s ki: Katalog prałatów s. 26-27.

89 Zmarł w r. 1753; W i śn ie w ski: Katalog prałatów s. 92-93.

$80_{a}$ Malarz i pisarz, żył $\mathrm{w}$ 1. 1656-1705. Jest też autorem dzieła: Miraculosa Virgo Cellensis votive e sacris litaniis lauretanis pro pace exorata... Gratz 1694. Por. J. Vercoullie. W: Biographie nationale publiée par l'Academie Royale. des Sciences, des Lettres et des Beaux-Arts de Belgique. T. 18. Bruxelles 1905 szp. $821-822$.

90 Enc. Chelm. T. $11 / 12$ s. 2. 


\section{$\mathrm{Nr} 58$}

426. Łac. 2 poł. $X V$ w. (1468). $30 \times 22 \mathrm{~cm}$. K. 210. Opr. deski w sk. wspt.

Komentarze biblijne i kazania.

1. k. 1-7v. Wykład ze wstępu do Pisma św. po otrzymaniu sitopnia magistra luib bakałarza teologii. „Psallam Deo meo quamidu fuero. Nolite confidere in principilbus".

2. k. 7v-200. Komentarz na Psalmy (od k. 1 do 140). „Beatus vir, qui non ambulavit... Incipit liber ymnarum vel soliloquiorum prophetae $\mathrm{X}$ Ad fructificandum super Evangelium et fructificandum tam dissipata est".

3. k. 205-210. Dwa kaizania na uroczystość Bożego Ciała. „Et egressus Iesuis cum discipulis suis $\mathrm{X} O$ maledictores vae voibis".

4. k. 207. Notia: "hi sunt prohibendi ab accessu ad communionem“.

K. 201-204 czyste.

Na przedniej karcie ochronnej verso napis: „Iste liber est conscriptus pro $W$ [enerabili] $p[r i o r e]$, vic[ari] is provincie Mariane [?] ec[clesie] sancti [?] Michaelis de Radomsko [?] qui largitus est sibi per [...] amicissimorum [!] caris suorum 1468" 91

Pismo dwu rąk, w dwu kolumnach. Podkreślenia i inicjały czerwone, rzadziej zielone i zlote.

Skladki : 18 seksternionów, ostatni z połową kart.

$\mathrm{Zn}$ aki wodne: dzwon, Briquet 3976, Piekosiński 592, Lichaczow 458. Drugi znak wodny niewyraźny.

Oprawa: deski jesionowe, obciągnięte cielęcą skórą $\mathrm{z}$ wytłoczonymi znakami: gwiazdą sześcioramienną, gryfem, lwem heraldycznym i barankiem wielkanocnym. $\mathrm{Na}$ przedniej okładce znaki w kółkach, na tylnej - lew w tarczy herbowej.

7 guzów ochronnych z mosiądzu.

Na grzbiecie 2 nalepki z XVIII w. z sygnaturami bibliotecznymi: na górnej „54“", na dolnej „No $10^{\text {" }}$.

Rękopis mikrofilmowany $w$ Bibliotece Narodowej w Warszawie.

\section{$\mathrm{Nr} 59$}

309. Pol. 1 pot. $X X w .28 \times 22 \mathrm{~cm}$. K. 66. Masz. Opr. brosz.

Ks. Kazimierz Gos't y ńs ki: „Droga do życia wiecznego i doskonałość ewangeliczna na tle rozmowy Chrystusa z bogatym młoidzieńcem - Mt 19,16-22; Mk 10,17-22; Łk 18,18-23“. Rozprawa naukowa, napisana po r. 1923.

\section{$\operatorname{Nr} 60$}

931. Pol., łac. $1661-1676.32 \times 10 \mathrm{~cm}$. S. 82. Opr. tekt. XIX w.

Ks. Stranisław P raski ${ }^{92}$ : „Wiadomości różne, zebrane z całej Polski, przy kościele białaczowskim pisane". Zbiór notatek o ówczesnych wydarzenialch.

Na okł. i s. 1-2 uwagi ks. Jana Wiśniewskiego i Walerego Przyborowskiego o autorze.

91 Odczytanie nie jest pewne. Dotychczas podawano $w$ katalogu: „Liber conscriptus per Mathiam et Michaelem de Radomski“. Choć Mathias de Radomski jest notowany w Acta rectoralia Almae Universitatis Studii Cracoviensis (ed. W. Wislocki. T. 1 , fasc. 1. Cracoviae 1893) s. 76,79 , inr 347,367 , to jechak dane paleograficzne całości napisu nie pozwalaja na identyfikację tych osób.

92 Por. ks. J. W iśn i e w ski: Monografia dekanatu opoczyńskiego. Radom 1913 s. $20-21$. 
Paginacja współczesna,

Dar ks. Jana Wiśniewskiego.

\section{$\mathrm{Nr} 61$}

847. Pol. 1851 r. $32 \times 21,5 \mathrm{~cm}$. S. 20. Zeszyt.

„Krótka wiadiomość o kościele parafialnym w Bądkowie Kościelnym, przez [Wincentegol Hipolita G aw a r ecki e g ${ }^{\prime \prime 93}$.

$\operatorname{Nr} 62$

473. Łac. 2 pot. XV w. 30,5×21 cm. K. 170. Opr. deski w sk. wspt. Rozprawy kanonistyczne i kazania.

1. k. 1. Fragment dzieła: "Consanguinei cum non sin affines $\mathrm{X}$ die restituit. Joannes Andrea e doctor decretorum compilavit hanc summulam" 94. Papier z przełomu XIV i XV w.

2. k. 2-10. "Incipiunt casus arbitrii per venerandum dominum $\mathrm{S}$ a $1 \mathrm{v}$ an um de Bolonia [?] decretorum doctorem editi, nunc in studio Quinque Ecclesiis degentem X .. super verbo honor et novella .." $\mathrm{Na}$ końcu podpis: Fredericus.

3. k. 11. Wycinek kartki z pracy kanonistycznej.

4. k. 12-93v. Kazania niedzielne i świąteczne od I niedzieli adwentu.

5. k. 95-118. Teksty biblijne: ,Ehia populi mei. X Ego sum Dominus".

6. k. 119-133. Kazania: „In ramis palmarum X Amen. Iesus, Maria“.

7. k. 133-170. Kazania pisane inną ręką: „Scitis, quod fecerim vobis ... serma de Corpore Christi X Miror id quidem digna fuit, ex qua Dei filius nasci voluit..."

K. 130 czysta.

Do olkładki przedniej przyklejony listek papieru $\mathrm{z}$ tekstem biblijnym: „In diebus illis locutus est Deus", z XIV w.

Pismo wielu rąk, w 2 kolumnach.

W niektórych częściach inicjały i tytuły czerwone.

Skladki: 2 kwaterniony, w tym 1 zdefektowany $i 13$ seksternionów.

$\mathrm{Znaki}$ wodne: zarys wieży zbliżony do Briquet 15876 oraz niewyraźny zarys ptaka i kontury glowy rycerza; trudne do zidentyfikowania.

Oprawa: deski dębowe obciągnięte skórą z tłoczonymi ornamentami roślinnymi. Resztka zamknięcia mosiężnego.

Na grzbiecie 2 nalepki z XVIII w. Na górnej ślady napisu: „Sermones dominicales", na dolnej liczba ,,56“.

Rękopis oddany do mikrofilmowania w Bibliotece Narodowej w Warszawie.

$$
\mathrm{Nr} 63
$$

1417. Eac. 1728 r. $19 \times 16 \mathrm{~cm}$. K. 157. Opr. tekt. wspl.

Formularze czynności prawnych.

1. k. 1--73. „Formulare officii per me Addamum in Ulatow Ulatow s $\mathrm{k} i$ in cancellaria Cracoviensi descriptum anno $1728^{\prime \prime}$.

2. k. 1-84. „Formulare inscriptionum“.

Foliacja współcz.

93 Żyl w 1. 1786-1852; Ks. M. Ży w cz.y ń ski: Gawarecki Wincenty Hipolit. W: Pol. stown. biogr. VII $312-313$.

94 Por. Schulte, jw. Bd 2 s. $214 \mathrm{nn}$. 


\section{$\mathrm{Nr} 64$}

423. Łac. XV w. (1413 r.) $29 \times 21 \mathrm{~cm}$. K. II, 256. Opr. deski $w$ sk. wspt. 95

"Linea salutis" Hier on ima z Pragi ${ }^{96}$ i kazania różnych autorów na niedziele, święta i uroczystości świętych.

K. 1 ochronna perg. Fragment łacińskiego traktatu gramatycznego, XIV w.

1. k. 1-115. „Linea salutis" Hieronima z Pragi.

K. 1. „Vae mihi quia tacui. Hec verba dicit Isaias propheta $\mathrm{X}$ O summa societas et summum desideratum bonum. Ad quod nos perducat Ihesus Christus dominus noster, qui cum Patre et Filio [?] et Spiritu Sancto vivit et regnat Deus per infinita secula seculorum. Amen. Explicit linea salutis. Et est finitus sub anno Domini $\mathrm{M}^{\circ} \mathrm{C}^{\circ} \mathrm{C}^{\circ} \mathrm{C}^{\circ} \mathrm{C}^{\circ} \mathrm{XIII}^{\circ}$ “

K. 115. „Ego enim accepi a Domino, quod et tradidi vobis. Epistola hodierna est beati Pauli..." Drugie kazanie: k. $115 \mathrm{v}$ "Caro mea vere est cibus X Explicit sermo de Corpore Christi. Amen".

3. k. 117. Różne notatki, m. in.: „Dominicis diebus faciat sic exhortationem... dicat... Pater noster... Ave Maria... fructus ventris tui Thesús Christus. Amen. Credo..."

4. k. $117 \mathrm{v}-119 \mathrm{v}$. Różne perykopy ewangeliczne i lekcyjne.

5. k. 120-244. Nieuporządkowany zbiór kazań różnych autorów na niedziele, święta i uroczystości świętych, spisany przez kilka rąk zmieniających się niekiedy nawet $w$ środku zdania. Przy niektórych kazaniach podano ich autorów: na k. 174, 190, 191v, 200, 208 jest notatka Sczkna, Magistri Sczekna [Śtekna] ${ }^{97}$ itp., na k. 188, 193, 206, 209v Proczywa, Prociva [Protival ${ }^{98}$ ito. na k. 195 - Benesius ${ }^{99}$, na k. 218 - Sermo C a c a bi [Catabi] ${ }^{100}$ de sancto Ioanne.

6. k. 245-250v. Dialog św. Anzelma z Matką Bożą.

K. 245. "Passio Domini nostri Ihesu Christi secundum Anselmum. Sanctus Anselmus longo tempore cum lacrimis et orationibus et ieiuniis rogabat $\mathrm{X}$ qui eam oderunt, toto corde ei compaciebantur. Et cetera. Et sic est finis, laus sit Christo".

7. k. $250 \mathrm{v}-256$. Dwa kazania: "Sermo in ramis palmarum" oraz „De novo sacerdote".

95 P. drowi Jerzemu Woronczakowi składam bardzo serdeczne podziękowanie za pomoc przy opracowywaniu tego rękopisu.

96 Por. A. B r ü ckner: Literatura religijna w PoIsce średniowiecznej. T. 1. Warszawa 1902 s. 34 nn.

97 Jan Štěkna, mistrz uniwersytetu praskiego i profesor akademii krakowskiej, cysters, pleban w Przemankowie i kapelan królowej Jadwigi zmarł ok. r. 1407; por. Brü ckner, jw. s. 37 n; Ks. J. Fija lek: Studia do dziejów uniwer sytetu krakowskiego i jego wydziału teologieznego w XV w. Kraków 1899. Rozpr. Akad. Um. Wydz. Filol. Seria 2. T, 14 s. $62-71$.

9s Jan Protiva $z$ Nove Vsi, kaznodzieja kaplicy betlejemskiej $w$ Pradze $w$ latach 1391-1396, później proboszez w kościele św. Klemensa w Pradze na Nowym Mieście, przeciwnik Husa; Z. N e je d Iy: Dějiny husitskégo spěvu. Kn. 2. Praha 1954 s. $98-99,159-161, \mathrm{kn}, 3$ s. 42.

99 Magister Benesius wspomniany w kolofonie rękopisu "petersburskiego"

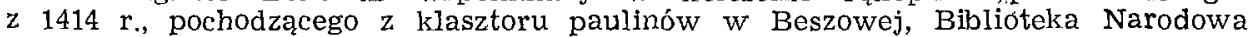
w Warszawie, Lat. I F. 496.

100 Prawdopodobnie jest to magister Catabus, polskiego pochodzenia, wymieniony na k. 15 rękopisu I F 609 Biblioteki Uniwersyteckiej we Wrocławiu. 
8. k. 256v. Trzy perykopy ewangeliczne.

K. 2 ochronna, perg. Fragment brewiarza (Officium defunctorum) z XIV w.

Tylna wyklejka papierowa $z$ tekstem "Bogurodzicy" $z 2$ poł. XV w. Tekst obejmu e 14 zwrotek: $1-8,9,10,11,12,14,15$ czyli wszystkie "kanoniczne" oprócz 14. Pisany in continuo ${ }^{101}$.

Notatki proweniencyjne $z$ końca XV lub pacz. XVI w. Na k. 256v: „Liber pro usu fratri Martino per patrem Marianum Vycewicz. [?]“. Na wewnętrznej stronie przedniej okladki: "Liber pro usu fratri... datum per patrem Vitum [?]".

Pismo wielu rąk, w 2 kolumnach. W tekście spotyka się slowa polskie. Inicjały, napisy i podkreślenia koloru czerwonego.

Skladki: 22 seksterniony, ostatni uszkodzony.

$\mathrm{Znak}$ wodny: glowa wolu z różyczką 7-listną, zbliż. do Piekosiński 1011.

Oprawa: wspólczesna, deski dębowe obciąnnięte skórą z wytloczonymi przekątnymi. 8 żelaznych guzów ochronnych. Rzemienie do związywania. Na grzbiecie nalepka z XVIII w. z cyfrą "2“.

Proweniencja: klasztor bernardynów w Radomiu.

Rękopis zmikrofilmowany przez Bibliotekę Narodową w Warszawie, nr 18009.

$\mathrm{Nr} 65$

427. Łac. 2 poł. $X V$ w. (1453-1454). $30 \times 21 \mathrm{~cm}$. K. 273. Opr. deski w sk. wspt.

„Evangelia dominicalia per circulum anni dicta Magistri Pa uli [Pawła z Zator'a] praedicatoris castri Cracoviensis" 102.

K. 2-271. „Sancti Spiritus a'dsit nobis gratia $\mathrm{X}$ anno Domini millesimo quadringentesimo quinquagesimo quarto“. K. 107v: „Finitae sunt quinta feria in Vigilia Margaritae virginis per manum $\mathrm{J}$ o a $\mathrm{n} n$ is presbiteri in Radom, in nova civitate anno Domini MCCCCLIII".

$\mathrm{Na}$ k. 1 ochronnej notatka ks. Józefa Rokosznego z 1903 r. o przesłaniu polskich słow $z$ tego kodeksu Aleksandrowi Brücknerowi.

K. 272-273 czyste.

Między początkowymi i końcowymi składkami falce $z$ pergaminowego rękopisu liturgicznego $\mathrm{z}$ XIV $\mathrm{w}$.

Pismo jednej ręki. Inicjały i podkreślenia czerwone.

$\mathrm{Sk} l$ a dki: 23 seksternionów, w tym ostatni zdefektowany.

Znak wodny: góra, Briquet 11785 .

Oprawa: deska dębowa obleczona skórą gladką, wyciśnięte przekątnie. Guzy ochronne mosiężne w kształcie kapelusza.

Rękopis oddany do mikrofilmowania w Bibliotece Narodowej w Warszawie.

$\mathrm{Nr} 66$

428. Eac. 2 pol. $X V$ w. $31 \times 21,5 \mathrm{~cm}$. K. 160. Opr. deski’ w sk. wspl. Kiazania.

1. k. 1-49. „Incipiunt sermones dominicales et festivales collecti a domino Cantore ecclesiae $\mathrm{Prim}$ is $\mathrm{C}$ e $\mathrm{ns}$ is et magistro artium studii condam [!] Prahensis ${ }^{103}$. Dominus ipse est salus in ventre Virginis per* carnem assumptus $X$ Et ipsa summa caritas nos benedicat et perducat in vitam eternam. Amen“.

101 Por. ks. A. Knothe: Nieznany dotąd odpis pieśni Bogarodzica. Prz. katol. R. 24: $1886 \mathrm{nr} 48$ s. 757-758; J. B ir kenma je r: Bogarodzica Dziewica. Lwów 1937 s. $22-24$ i tabl.

102 Ży W I. 14.13-1463, kanonik krakowski, autor ,Expositio in Evangelia dominicalia"; Enc. Chelm. T. 31/32 s. 12; Ks. J. Pel czar: Zarys dziejów kaznodziejstwa w Kościele Katolickim. Cz. 2. Kraków 1896 s. 60; W. B r u c hn a lski: Rozwój wymowy w Polsce. W: Dzieje literatury pięknej $w$ Polsce. Cz. 2. Kraków 1918 s. $270-271$.

${ }_{103}$ Możé Mikołaj syn Wiganda; Pelczar, jw. Cz. 2 s. 58-59. 
2. k. 51-158. Kazania na uroczystości świętych. „Elisabeth impletum est tempus pariendi $X$ quod nobis prebere dignetur idem Dominus qui est benedictus in secula seculorum. Amen". Wśród kazań są na k. $81 \mathrm{v}$ „De translatione sancti Stanislai", k. 83v „De sancto Venceslav", k. 88 "De sancta Hedwige", k. 112 "De conceptione beate Virginis Marie", k. 134v „De sancto Adalberto", k. 249v „De sancto Sitanisilao patrono meo" 104.

Na wyklejce przedniej okładki współczesny spis kazań na dni świętych.

K. $50,159-160$ czyste.

Nieliczne glossy polskie na marginesach.

Pismo 2 rąk na przemian, w dwu kolumnach.

Inicjaly i podkreślenia minią. W drugiej części do inicjalów użyto także farby niebieskiej.

Skła dki : 14 seksternionów, w tym ostaitni zdefektowany.

Znaki wodne: na karcie ochronnej głowa wolu z krzyżem i wiatrakiem zbliż. do Briqueta 14540. Na k. 14, 16, 20 góra z różyczką 3-listnă, znak nie notowany $w$ podręcznikach. W drugiej części glowa wolu z różyczką 7-listną, Briquet 14777. Czwarty znak wodny niewyraźny, podobny do winogrona.

Op r a wa: podniszczona, skóra ze śladami ornamentów geometrycznych i roślinnych. Resztkí spinaczy skórzanych.

Na grzbiecie 3 naklejki z XVIII w. z napisami: na jednej - "Sermones dominicales ... Premisliensis ... 201", na drugiej - "Ignoti authoris", na trzeciej — "47".

Kodeks przeznaczony do mikrofilmowania $w$ Bibliotece Narodowej $w$ Warszawie.

\section{$\operatorname{Nr} 67$}

435. Eac., pol. $1614-1643$ r. $19,5 \times 16 \mathrm{~cm}$. S. 820. Opr. skóra tłoczona, wspt.

Ka'zania i rozprawy teol.

1. s. 1-774. "Conceptus seu discursus praedicabiles pro dominicis et festis diebus accomodati per me Joannem Andream Dab row ski can. Eowicensem eiusdem ecclesiae concionatorem ordinarium, in Srebrne Górki parochum A. D. 1614 inceptum, anno 1619 finitum".

2. s. $775-786$. "In festo porciunculae apud PP. Franciscanos 1643".

3. s. 787-820. "Elucidarius dialogicus omnibus s. theologiae studiosis perutilis"s".

Proweniencja: „Ex libris Congr. Orat. Studziannae“.

\section{$\mathrm{Nr} 68$}

374. Pol., łac. 2 pot. XVII w. (1663-1665). $20 \times 15 \mathrm{~cm}$. K. 226. Opr. bez okładek.

Kazanila i materiały kaznodziejskie.

1. k. 1-27. Różne kazania.

2. k. 27-34. Concio in festo S. Jacobi Ap. X. Kordanowskie [?], karmelity bosego we Lwowie.

3. k. 34-49. Kazania różne.

4. k. 51-72. Materialy kaznodziejskie.

5. k. 73-100. Różne kazania.

6. k. 103-115. „Lilia 'z królów polskich i słońce Kościola Chrystusowego albo kazania na dni świętych Kazimierza królewicza i Tomasza z Akwinu milane od X. Mikołaja S z o mow s k i e g o ${ }^{105}$ w r. 1655“. De-

104 Sam napis dokonany był ręką późniejszą, z XVI w.

105 Estr. XXX 292 podaje tylko kazanie tegoż autora na W. Piątek. 
dykacja: „X. Kazimierzowi Szczuce, proboszczowi warszawskiemu, łomżyńskiemu, kanonikowi krakowskiemu etc., sekretarzowi J. Król. Mości“.

7. k. 116-127. „Wdowa albo na niedzielę XV po świątkach kazanie miane i do druku poldane od X. Mikołaja Szomowskiego".

Rękopis nie ma początku i końca. Pismo różnych rąk.

$\mathrm{Nr} 69$

375. Pol., łac. 1684 r. $20 \times 15,5 \mathrm{~cm}$. K. $348+332$. Opr. bez oktadek.

Kazania.

"Vera supellex Matthiae Stanislai Pęczkowi c Chęcinensis, ordinarii concionatoris, mansionarii ecclesiae parochialis $\mathrm{S}$. Stephani et Ursulae in Skrzynno post fata Sebastiani Bolmiński Chęcinensis, concionatoris Skrzynnensis ${ }^{106}$ anno 1684 die 6 martii mihi oblata".

Brak początku.

Proweniencja : kościół w Skrzynnie.

$\mathrm{Nr} 70$

405. Eac., pol. 1684 r. $16 \times 10 \mathrm{~cm} . K .176$. Opr. pergamin z zatartym pismem, wspt.

Kazania.

1. k. 1-53. „De Ecclesia“ - zarzuty heretyków i odpowiedzi na nie.

2. k. 54-151. "Conciones selectae pro nonnullis festis et dominicis, scriptae Cracoviae".

3. k. 152-176. „Varia fragmenta scripta et notata 1683 Scrinnae“.

Pismo wielu rąk.

Proweniencja: „Ex bibliotheca Mathiae Stanislai Peczlowic [winno być: Pęczkowic] concionatoris et mansionarii Scrinnensis. A. D. 1684 subscripsi mpp".

$\mathrm{Nr} 71$

463. Eac. 1785 r. $15,5 \times 10,5 \mathrm{~cm}$. K. 47. Opr. brosz. wspt.

Kazania, począwszy od niedzieli wielkanocnej aż do niedzieli palmowej. „Explicatio Evangeliorum ac Epistolarum scripta ac notata... per Josephum G lac A. D. 1785 scholae humanit. mpp."

$\mathrm{Nr} 72$

408. Łac. 1707 r. $15,5 \times 9,5 \mathrm{~cm}$. K. 60. Opr. brosz. wspt.

Zasady i ćwiczenia $z$ poetyki.

1. k. 1-47. "Geminus bicollis Parnassi vertex oratorio poeticis circumfusus fluminibus seu breve artis oratoriae ac poeticae compendium, scriptum per me Martinum Jasiński107 A. D. 1707“.

2. k. 48-60. „Versio poetica, proverbiorum Salomonis".

$\mathrm{Nr} 73$

1086. Eac. 2 pot. $X V$ w. (1481 r.). $22 \times 16 \mathrm{~cm}$. K. 150. Opr. deski $w$ sk. wspt.

Dzieła literackie i teologiczne.

1. k. 1-23. Dialog Petrarki „De contemptu mundi“. „Secretum Francisci Petrarche de Florentia poete laureati de contemptu mundi $\mathrm{X}$ fuit

100 Por. ks. J. Wiśniew ski: Monografie kościolów w dekanacie opoczyńskim. Radom 1913 s. $181-182$.

jo7 Wiśniewski: Katalog prałatów s. 92-93. 
infra sex dies per Stanis la $\mathrm{S}$ m de Corzys in Schydzyna [?] ${ }^{108}$ villa scriptum feliciter anno Domini MCCCCLXXXI VII augusti, pro quo sit benedictus Deus in secula seculorum amen".

2. k. 25-66. Diallog Petrarki „De vita solitaria“. "Liber Francisci Petrarche poete laureati de vita solitaria X Explicit liber primus de vita solitaria". k. 40 "Incipit secundus. Caput primum. De laude vite solitarie et multis exemplis solitariorum X Qualiter solitarius debet vivere... Bene suades. Vertens... verum dictum".

3. k. 67-131. Dzieło „Speculum vite humane" [napis inną ręką]. „Ad sanctissimum et beatissimum dominum dominum Paulum secundum pontificem maximum liber incipit dictus speculum vite humane... editus a Roderico Zamorensi ${ }^{108}$ et postea Calogavitano Hispano eiusdem sanctitatis in castro suo sancti angeli castellano $X$ a Stanislao de Corzys scriptus anno a partu Virginis salutifero millesimo quadringentesimo octogesimo primo“. k. 130: "Incipit repertorium sive tabula per alphabetum $\mathrm{X}$ finis tabule super speculum vite humane".

4. k. 133-150. Dzieło Grzegorza Wielkiego "Dialogi de vita et miraculis patrum Italicorum". "Quadam die nimiis tumultibus... Liber primus dialogorum. Petrus. Non valide aliquorum in Italia virtutibus vita fulsisse... Gregorium..." k. 141: „Secundus liber de vita slancti Benedicti X regis secreta“. Brak końca.

K. 24,132 czyste.

Na wyklejce przedniej okladki notatka z XV-XVI w. „Liber magistri Stanislai de Corzys".

Falce przy początkowej i ostatniej składce sporządzone $z$ rękopisu pergaminowego $z$ resitką tekstu $z$ XIII-XIV $w$.

Pismo jednej ręki. Niektóre tytuły pisane inną ręką. Inicjały czerwone i niebieskie.

Sk 1a d ki: 13 seksternionów, w tym ostatni zdefektowany.

$\mathrm{Znaki}$ w od n e: prawdopodobnie całość stanowi głowa wołu z krzyżem, oparta na koronie $z$ dwoma liśćmi i trzema różyczkami trzylistnymi, zbliż. do Briqueta 14562 i Piekosińskiego 1668; krzyż i wąż, zdobiący zapewne głowę wolu, zbliż. do Piekosińskiego 1090; trzeci znak trudny do określenia.

O p r a wa: deski dębowe obciągnięte cielęcą skórą z wytłoczonymi ornamentami geometrycznymi, roślinnymi i alegorycznymi. Nadniszczona. Ozdobne klamry do zamykania. Na grzbiecie 2 nalepki z XVIII w. Na jednej napis zatarty, na drugiej „N"“.

Proweniencja: na wyklejce przedniej okładki napis „Do Biblioteki Seminarium Sandomierskiego ofiarowal ks. Jan Wencel, proboszcz żarnowski, w kwietniu 1908 r.".

Rękopis przeznaczony do mikrofilmowania w Bibliotece Narodowej w Warszawie.

\section{$\mathrm{Nr} 74$}

1688. Eac. 1574 r. $30 \times 21 \mathrm{~cm}$. S. 398. Opr. skóra wspt.

Kopiarz wierszy Andrzeja Krzy ckiego. „Poemata Andreae Cricii episcopi“. Prodpis: „Francisci Pegowski, canonici Chełmensis, prae-

108 Prawdopodobnie jest to Stanisław Korzyb (,magister Stanislaus de Corzip") prof. Uniwersytetu Jagiellońskiego i bernardyn. Zmarl w r. 1491. Por. Acta rectoralia. T. 1, $\mathrm{nr} 240,244,245,298 ; \mathrm{K}$. M o r a w s kti : Historia Uniwersytetu Jagiellońskiego. T. 2. Kraków 1900; Ks. K. Kantak: Bernardyni polscy. T. 1. Lwów 1933 s. 281.

108a Rodericus Santius de Arevalo, biskup Zamory, autor cżęstokroć wydawanego $\mathrm{w}$ XV w. dzieia: Speculum vitae humanae. Żyl w 1. 140'4-1470. Ch. Gr. Jöcher: Gelehrtes Lexikon. Fortsetzung. Bd 7. Leipzig 1897 s. 204. 
positi Obrazzoviensis". Na okładce wśród wytłoczonych ornamentów herb Odrowąż, litery S. C. oraz 1574.

Rękopis przeznaczony do mikrofilmowania Bibliotece Narodowej w Warszawie ${ }^{109}$.

$\mathrm{Nr} 75$

1707. Pol. $X X$ w. $20,5 \times 16,5 \mathrm{~cm} . S$. 80. Opr. - luźne kartki i składki.

Zdobycie Sandomierza w 1809 r. Przygody sierżanta 12 pułku piechoty Księstwa Warszawskiego. Napisał Walery Przyborowski.

\section{B. DUCHOWIENSSTWO ZAKONNE}

\section{BERNARDYNI}

a) GRODNO

$\mathrm{Nr} 76$

705. Eac. $1704-1706$ r. $29,5 \times 20,5 \mathrm{~cm}$. S. $474,86,78,172$. Opr. tekt. wspt.

Skrypity z wykładów.

1. k. 1-474. „Physica Aristotelis ad mentem Doctoris Subtilis in conventu Gradnensi ad Sanctam Crucem sub guardianatu Antonii Horbaczewski ${ }^{110}$ per Sebastianum Bosman die 22 Novembris 1704, finitum 14 februarii $1706^{\prime \prime}$.

2. k. 1-86. „De mundo et coelo - in librum Aristotelis De coelo et metheoris iuxta mentem Doctoris Subtilis".

3. k. 1-78. „De generatione et corruptione“.

4. k. 1-172. "De anima".

b) KRAKOW

N'r 77

560. Łac. $1729-1730$ r. $19,5 \times 15,5 \mathrm{~cm}$. K. 196. Opr. tekt. wspt. nadniszcz.

Skrypty z wykkadów teologii.

1. k. 1-121. "Duo testamenta... in valle... Stradom ad S. Bernardinum per Ioannem Capistránum Pała $\mathrm{niecki}$ i11 in 2-dum et 3-tium Sententiarum libros extradita 18 iunii 1729 anno". k. 1-55: „,De angelis". k. 56-71: "De homine variisqque sitatibus naturae humanae". k. 72-80: „De peccatis“. k. 81-121: „De gratia, die 27 sept. 1730“.

2. k. 122-196. „Liber III Sententiarum Ioannis Scoti de mysterio incarnationis, theologicis alumnis in conventu Cracoviensi a P. Ioanne Połaniecki 30 sept. 1730 [traditus]. Scripsit F. Bartholomaeus Kulbiński“.

109 Rękopis wykorzystywany był do badań naukowych w Bibliotece Jagiellońskiej w Krakowie $i \mathrm{w}$ Ossolineum we Wroclawiu. Niektóre $z$ wierszy religijnych thumaczył na podstawie tego kodeksu ks. A. Bułakowski; Zob. Kron. Diec. sandom. R. 4: 1911 s. $161-163,5$ : 1912 s. $33-34,113-114,165,373$.

110 Informacji udzielił łaskawie o. prof. dr Hieronim Wyczawski na podstawie akt Archiwum Prowincji Bernardynów w Krakowie.

111 Estr. XXIV 436 . 


\section{$\mathrm{Nr} 78$}

556. Eac. 1734 r. $19,5 \times 15 \mathrm{~cm} . K .280$. Opr. tekt. wspt.

Skrypty z wykładów.

1. k. 1-118. „Lux theologica increatae lucis lucem per primum Sententiarum librum iuxta mentem... Ioannis Duns Scoti... diffuden... per P. Ioannem Połaniecki anno 1734 explicata".

2. k. 123-141. "De actibus humanis".

3. k. 148-280. „Fons sacramentalis a subtili Mariano Doctore per IV Sententiarum librum diffusus in valle Stradomiensi ad S. Bernardinum a $\mathrm{P}$. Bartholomaeo $\mathrm{Kulbiński}$ secretario provinciae iurato monstratus 20 nov. 1734".

$$
\mathrm{N} \times 79
$$

572. Eac. 1784 r. $23,5 \times 18,5 \mathrm{~cm}$. S. 589. Opr. tekt. wspt.

Podręcznik teologiczny. „Theologia scholastico-dogmatica iuxta Doctoris Subtilis principia per F. Victorinum W i I t a w s k i O. F. M. Observ. in Gymnasio Cracoviensi ad S. Bernardinum in lucem edita. Tomus III". s. 1-97: „De actibus humanis“. s. 97-158: „De legibus“. s. 158-258: „De peccatis". s. 259-379: „De virtutibus theologicis". s. 379-473: „De virtute religionis". s. 473-589: „De iustitia“. „Index materiae".

Nr 80

569. Łac. 1787 r. $23,5 \times 18,5 \mathrm{~cm} . S .428$. Opr. tekt. wspt.

Podrecznik teologiczny. „Theologia scholastico-dogmatica... iuxta veriora Doctoris Subtilis principia ad usum studiosae iuventutis accomodata... per F. Victorinum Wiltawski O. S. Franc. Observ. in Gymnasio Cracoviae ad S. Bernardinum 1787 a. exhibita. Tomus IV".

1. s. $1-116$. „De regulis fidei“.

2. s. 117-296. "De vera Christi Ecclesia“.

3. s. 297-387. „De statu animae a corpore separatae et de indulgentiis".

4. s. $387-428$. „De adoratione Christi et cultu sanctorum, veneratione reliquiarum ac imaginum". "Index materiae".

$\mathrm{Nr} 81$

418. Eac. 1 poł. XVI w. (1530). 15,5×10,5 cm. K. 244. Opr. deski w sk. wspt.

Kazania.K I e m e n a $\mathrm{z} \mathrm{R}$ a d y $\mathrm{mn}$ a $^{112}$ oraz traktaty kanonistyczne innych autorów.

1. k. 1-207. Kazania na niedziele, uroczystości świętych i święta. k. 1-161: „Dominica septuagesima de paucitate salvandorum X Dominica infra octavam Ascensionis“. k. 162-206: „De sancto Adalberto sermo X In festo sanctorum apostolorum". k. 207: „Dominica rogationum post prandium de epistola Jacobi $X$ calamitas ad quam miseri mortales in hac vita..."

2. k. 207-244. Traktaty kanonistyczne o podziale i treści Dekretałów, z XV-XVI w. „Tituli Sexti Decretorum, tituli Clementinarum X De modo scribendi et legendi in iure".

${ }_{112}$ W r. 1529-1531 pracowal w Krakowie, zmarl 4 IV 1562; Ks. K. K a n tak, jw. s. $230-234$. 
K. 126-128 czyste.

Wklejone później paski z dodatkami do kazań. Przednia kartka ochronna perg. $z$ tekstem rytualu $z$ pocz. XV w.

$\mathrm{Na}$ wewnętrznej stronie okładki napis ręką ks. Ludwika Piotrowicza z końca XIX w. "Clemens de Radimno, Sermones, ca 1530 ".

Pismo wielu rąk. Podkreślenia i komentarze tekstów prawnych czerwone.

Sk la d k i : 23 kwaterniony i 5 seksternionów, niektóre składki uszkodzone.

Znaków wodnych nie ma. Teksty prawne wpisane na papierze innego gatunku.

Oprawa: deski dębowe, obciągnięte skórą cielęcą $z$ wytłoczonymi ornamentami geometrycznymi i roślinnymi. Ślady ozdobnych klamer do zamykania. $\mathrm{Na}$ grzbiecie 2 nalepki $\mathrm{z}$ XVIII w.: na górnej napis zatarty, na dolnej sygnatura: 256 VI.

Rękopis mikrofilmowany w Bibliotece Narodowej w Warszawie.

c) OPATÓW

Nir 82

691. Eac. $1678-1680$ r. $18,5 \times 14,5 \mathrm{~cm}$. K. 267. Opr. tekt. wspl. nadniszczona.

Skrypt szkolny.

1. k. 1-218. „Porta aurea-Ioannis Duns Scoti logica in conventu Opatoviensi per Michaelem $\mathrm{P} 0 \mathrm{c}$ is $\mathrm{z} 0 \mathrm{wsk}$ i reserata, per me vero Fr. Antonium Dzianott insculpta die 7 sept. A. D. $1678-12$ iunii $1679^{\text {". }}$.

2. k. 218-267. „Metaphysica. Die 4 maii 1680“.

$\mathrm{Nr} 83$

760. Eac. $1761-1763$ r. 19,5×15,5 cm. S. 194, 133. Opr. tekt. wspt. Skrypit szkolny.

1. s. 1-194. „Umibra philosophica... seu philosophia naturalis octo libris Physicorum illustrata, studiosae iuventuti seraphicae revelata ac per fratrem Io a $\mathrm{ch}$ i $\mathrm{m} \mathrm{u} \mathrm{m}$ minoritam... in aledibus Marianis Opatoviensibus reserata, die 31 martii $1761^{\prime \prime}$

2. s. 1-133. "Thesaurus valoris infiniti iuventuti in Athenaeo Opatoviensi explanatus iuxta Duns Sooti sensum, 10 maii 1763 , finitum 18 iunii 1763 Opatoviae, Fr. Mathias mpp."

Napis: „Hunc librum..Fr. Mathias Biegalski... applicavit pro eodem conventu Radomiensi die 14 iunii 1769 a. mpp".

Nr 84

750. Eac. 1762 r. $19 \times 15,5 \mathrm{~cm}$. S. 89. Opr. tekt. wsp.

Skrypty szkiolne.

1. s. $1-63$. „Methaphysica in conventu Opatoviensi per M a r c e II i a $\mathrm{n}, \mathrm{m}$ seraphici instituti professum adaptata, 22 nov. 1762, Fr. Mathials mpp."

2. s. 64-89. "Tractatus philosophico-moralis in libros moralium Aristotelis".

Napis: „Haec scripta pro conventu Radomiensi applicavit Fr. Mathias Biegalski, lector philosophiae, $1769 \mathrm{mpp}$ ".

d) PARADYZ

$\mathrm{Nr} 85$

761. Łac. $1767-1769$ r. $18,5 \times 15,5 \mathrm{~cm}$. K. 154. Opr. tekt. wspt.

Podręcznik szkolny. 
K. 1-154. „Campus universi... seu physica generalis iuxta mentem Ioannis Duns Scoti in conventu athenaeo Paradisiensi ad Iesum Coronatum per Fr. Severinum Schober, seraphici instituti regularis observantiae professum, studiosae iuventuti officioso calamo dilucidatus, die 8 Februarii 1767, denuo Pragae ad Warsaviam tradidi dialecticam, animasticam, mehaphysicam et hoc uti praedicator actualis Germaniae a. D. 1779 et $1780 \ldots$ finitum 12 iunii 1769 in conventu Paradisiensi ad Iesum Coronatum".

\section{$\mathrm{Nr} 86$}

733. Łac. $1769-1771$ r. $18,5 \times 15 \mathrm{~cm}$. K. 247. Opr. tekt. wspt.

Podręcznik szkolny.

1. k. 1-68. „Pharos scientiarum seu logica parva neo-scotistis in lycaeo Paradisiensi ad Iesum Coronatum per Severinum Schober proposita, 4 octoibris 1769, secundo in conventu Pragensi 9 sept. 1.779".

2. k. 69-189. „Rosetum Marianum seu logica magna ad Ioannis Duns Scoti mentem seraphicae scholae auditoribus concinnata, in conventu Paradisiensi ad Iesum Coronatum proposita a P. Severino Szober, tradita 30 Aprilis 1770".

3. k. 191-247. „Anagnostes seu metaphysica iuxta mentem Ioannis Duns Scoti enucleata in aede Paradisiensi ad Iesum Coronatum per Fr. Severinum Szober calamo officioso formata, die 22 novembr. 1771; secundo Pragae ad Warsaviam 9 ianuarii 1780".

e) PRZYROW

$\mathrm{Nr} 87$

551. Eac. 1779 r. $21,5 \times 17,5 \mathrm{~cm}$. S. 583. Opr. tekt. wspt.

Podręcznik szkolny.

„Fluvius gratiarum... in conventu Przyroviensi ad Sanctam Annam ab Victorino Wyltawski pomeridiano professore patefactus, 12 aprilis 1779. De sacramentus in specie tomus I." $\mathrm{Z}$ indeksem.

$\mathrm{Nr} 88$

526. Łac. 1781 r. $23 \times 18,5 \mathrm{~cm}$. S. 596. Opr. bez oktadek.

Podręcznik szkkolny.

„Exercitationes theologicae - de Deo eiusque attributis ad mentem Ioannis Duns Scoti theologiae candidatis in lycaeo Przyroviensi ad S. Annam per F. Victorinum Vyltawsky pomeridianum professorem diebus septembris anni 1781 inchoatae".

Brak ostatnich kart.

f) RADOM

$\mathrm{Nr} 89$

730. Łac. 1685 r. $19 \times 15 \mathrm{~cm}$. K. 216. Opr. brak okładek.

Podręcznik szkolny.

1. k. 1-157. „Logica, Radomiae 8 martis 1684, finitum 12 iulii 1685“.

2. k. 158-216. "Metaphysica iuxta Aristotelem in 12 libros divisa, Ordinis Minorum de Obs. philosophiae auditoribus ad discendum porrecta per Hilarium Bidzinski in conventu Radomiensi die 7 sept. $1685^{\prime \prime}$.

Brak trzech pierwszych artykułów. 


\section{$\mathrm{Nr} 90$}

740. Eac. 1732 r. $19,5 \times 15,5 \mathrm{~cm}$. K. 264. Opr. tekt. wspt.

Skrypt szkolny.

„Cursus philosophiae naturalis, continens octo libros physicorum, iuxta mentem Duns Scoti in conventu Radomiensi tituli S. Catharinae per Hieronimum $\mathrm{L}$ i s o w s $\mathrm{k}$ i philosophiae lectorem provectus, die 6 septembris 1772 “.

Napis: „Pro cella PP. Lectorum“.

$\mathrm{Nr} 91$

1613. Łac., pol. 1775 r. $22 \times 18 \mathrm{~cm}$. S. 76. Opr. skóra brazowa, wspl.

Hymny z nutami gregoriańskimi.

„Echo czyniące chwałę Bogu, zakon O. Benedykta zdobiące, odnowione za staraniem... Angeli Przyłuski mistrzyni nowicjackiej 20 maja 1775. Scripsit F. Stanislaus O.M. S. F. de Obs., vicarius conventus Radomiensis".

$$
\text { Nr } 92
$$

406. Łac. 1 pot. XVI w. (1530-1541 r.) i XVII w. $16,5 \times 11,5 \mathrm{~cm}$. K. 281. Opr. deski $w$ sk. wspt.

"Sermones Iacobi de S rzem O.F.M. de Obs." 113

1. k. 1-12. „Hoc tunc bonum super omnia alia bona $\mathrm{X}$ Et repleti sunt omnes Spiritu Sancto..."

2. k. $12 \mathrm{v}-14$. Kazanie ,in festo S. Jacobi Maioris“ z XVII w., w języku polskim.

3. k. 15-27. „...esse conspicit in reddenda ratione... X... invocationis salviferae..."

4. k. 29-197. Kazania na unoczystość Zielonych Swiąt i oktawę. ,Sermo pro die sacratissimo Penthecostes. De gratia quam quisque habet... X Venite ad me omnes etc. Finis sermonis".

5. k. 200-275. Kazania na Wniebowstapienie Pańskie i oktawę. ,Sermo de gloriosa ascensione Domini X Nihil est in homine, nihil est innoxium. Et sic patet".

6. k. 276. „Sermo de sancta Anna. Benedictus fructus ventris tui. $\mathrm{X}$ Septima humilitas. Ut in qualibet re..."

K. 107, 198, 199 czyste.

Falce przy ostatniej składce $\mathrm{z}$ rękopisu XIV-wiecznego.

Pismo wielu rąk. Podkreślenia i napisy czerwone. Nieliczne glossy lacińskie na marginesach.

Składki: 18 okternionów, wiele kart wydartych

Znaków wodnych nie ma.

Oprawa: deski jesionowe, resztki skóry z tłoczonymi ornamentami, slady klamer do zamykania. Na grzbiecie nalepka z XVIII w. z numerem, 257".

Rękopis zmikrofilmowany przez Bibliotekę Narodową w Warszawie, $\mathrm{nr} 18105$.

g) TARNOW

$\mathrm{Nr} 93$

716. Łac. 1743 r. $19,5 \times 15,5 \mathrm{~cm} . K$. 76 . Opr. tekt. wspt. Podręcznik szkolny.

${ }^{113} \mathrm{~K}$ a n tak, jw. s. $147-149$. 
„Logica ad menitem D. Thomae Aquinatis... per P. Alexandrum Ma1 yń sk i minoritam calamo et studio persoluta 30 augusti $1743^{\text {“. }}$.

Napis: „Pro studio Opatoviensi applicat Fr. Alexander Małyński, lector philosophiae Tarnoviensis, die 1 ianuarii $1747^{*}$.

\section{h) WILNO}

\section{$\operatorname{Nr} 94$}

520. Eac. $1686 r .21,5 \times 17 \mathrm{~cm}$. K. 307. Opr. tekt. wspl. zniszczona.

Skrypt szkolny.

1. k. 1-134. ,In I Sententiarum librum de Deo Trino et Uno... elucidationes sensui Ioannis Duns Scoti accomodatae 1686".

2. k. 135-230. „In librum II... exegeticon scholasticum in conventu Vilnensi a. 1686 inchoatum".

3. k. 232-307. "Exegeticon scolasticum in III librum Sententiarum".

i) Z NIEUSTALONYCH SRODOWISK

Nir 95

491. Eac. 2 polowa $X V$ w. (po r. 1482). 14,5X7 cm. K. 294. Opr. deski $w$ sk. wspt.

Kazania nieznanego bernardyna (Sermones bernardini ignoti). ${ }^{114}$

1. k. 1-272. „De virtutibus. De tempore“. k. 1: wykaz kazań — „de fide, de oratione, de praeceptis decalogi $\mathrm{X}$ dominica sexta post Pentecosten".

2. k. 275-282. Traktat teologiczny: „De dignitate anime X prosequi salutem. Visio".

3. k. $286 \mathrm{v}-228$. Traktat: „De oratione. Super omnia X ut et loqui concedio".

4. k. 289-294. Traktat o cnotach: „Non duabus dumtaxat X sed quoad stellarum permanenciam".

K. 283-285 czyste.

Pismo wielu rąk. Niektóre napisy, wyrazy i inicjaly czerwone.

$\mathrm{Sk} 1$ a dki: 12 seksternionów, reszta kwaterniony. Część składek zdefektowana.

$\mathrm{Zn}$ a k w o d n y : glowa wolu $\mathrm{z}$ wężem, zbliż. do Briqueta 15367 (Vincenza 1478).

Op $r$ a wa: deska jesionowa, powleczona skórą cielęcą. Wyciśnięte ornamenty roślinne $\mathrm{i}$ geometryczne. Slady klamry do zamykania.

Rękopis zmikrofilmowany w Bibliotece Narodowej w Warszawie, nr 18277.

\section{DOMINIKANIE}

a) BRZESC

Nir 96

739. Łac. 1745 r. $15 \times 9$ cm. K. 70. Opr. perg. $z$ tekstem liturg. $z X I V$ w., wspl.

Słownik filozoficzny. Skrypt szkolny.

„Compendium notandorum ex philosophia ordine alphabetico et prae-

114 Kantak, jw. s, 139 uw. 14 stwierdza, że ten i jeszcze dwa inne rękopisy sandomierskie $\mathrm{z}$ r. 1413 i 1468 (nr 64 i 58) pochodzą z książnic bernardynńskich. Zaznacza jednak w tekście, że nie doszły do nas prawie żadne kazania bernardyńskie $\mathrm{z} X V \mathrm{w}$. 
cipue definitionum... levamen laboris Fr. Simonis $\mathrm{Sz}$ a rwe y, studentis in conventu Brestensi in Lithuania Ord. Praied. anno Domini 1745 die 14 iulii". Podano hasła od A do R.

Napis: „Fr. Simonis Szarwey hic liber". $\therefore$

b) LUBLIN

\section{$\mathrm{Nr} 97$}

1765. Pol. 1758 r. $16,5 \times 10,5 \mathrm{~cm}$. K. 19. Opr. brosz. wspł.

Pouczenia lekarskie. „Ręką O. Jana Ewangelisty $R \mathrm{o}^{\mathrm{b}}$ i e c ki e g $\mathrm{o}$, S. Th. Doktora, przeora lubelskiego ojców dominikanów opisana wiadomość najciekawsza, każdemu człowiekowi chcącemu zdrowie swoje ocalić do wiedzenia wielce potrzebna“".

Proweniencja: „Z biblioteki klasztoru XX. Dominikanów Lubelskich“.

c) SANDOMIERZ

$\mathrm{Nr} 98$

709. Eac. 1844 r. $22,5 \times 19,5 \mathrm{~cm} . K .450$. Opr. tekt. wspt.

Skrypt wykładowicy filozofii.

„Philiosophia iuxta mentem Thomae Aq. ex manu scriptis Leopoldi Trybalski Ord. Praed.“

Proweniencja: Klimontów.

Nrr 99

570. Eac. 1845 r. $22,5 \times 18,5 \mathrm{~cm}$. K. 274. Opr. tekt. wspt.

Notatki do wykładów teologii.

„Abbreviata theologia dogmatica universalis Petri Leopoldi Trybalski, explanata in Seminario Dioecesano Sandomiriensi, 17 mari 1845 in conventu Sandomiriensi Sancti Jacobi“.

Nota: „Explicabat Antonius Misiurski“.

\section{$\mathrm{Nr} 100$}

613. Pol., łac. $1837-1866$ r. $22,5 \times 17,5 \mathrm{~cm}$. K. 568. Opr. tekt. wspt. Skrypty szkolne i rozprawy naukowe.

1. k. 1-342. „Rozprawa o czynnościach ludzkich, de legibus, de contractibus, iustitia et iure, de peccatis, de obligationibus, de virtutibus, de sacramentis - L. Trybaliski. Scripsit Justus Słykowski, Thimothaeus Sosiński“".

2. k. 343-373. „System chrystianizmu krótko wyłożony przez Józefa Kalasantego Szaniaw skieg o ${ }^{115}$ - dzieło czytane na posiedzeniu Towarzystwa Warszawiskiego Przyjaciół Nauk 5 maja 1803 r., pismo O. Marskiego, obywatela spood Zwolenia, 1866 r."

3. k. 379-408. „Obiectiones contra revelationem religionis solvuntur, Varsoviae 20. 12. 1837, pismo Maurycego $R$ o j k a vel Rojkowskiego".

4. k. 409-445. „De theologia eiusque divisione. Varsoviae 1837-8“.

5. k. 450-485. "Tractatus de religione, pismo Antoniego $\mathrm{S} 1$ o m c z yński e g o O. P.“

6. k. 486-523. „Patrologia“.

7. k. 524-551. „De creatione mundi. L. Trybalski".

115 Pijar, żył w l. 1709-1762; Enc. Chełm. T. 37/38 s. 355; Estr. IV 431. 
8. k. 552-568. „De officio divino“. i $1840 "$.

Druk: „Acta capituli provincialis Pol. Ord. Praed., Varsaviae 1837

Różne zeszyty i karty pozszywane $\mathrm{w}$ jeden tom.

Proweniencja: Klimontów.

$\mathrm{Nr} 101$

1390. Łac. 1844-1864 r. $22 \times 19 \mathrm{~cm}$. K. 410. Opr. tekt. wspł. zniszcz. „L. Trybalski, Historia ecclesiastica, 22 iulii 1844-1864“.

k. 112-116 zawiera listę prowincjałów dominikańskich w Polsce w latach 1224-1864.

Podpis: Fr. Aloisius Niezabitowski.

Proweniencja: Klimontów.

$\mathrm{Nr} 102$

1451. Łac. 1846 r. $21,5 \times 18 \mathrm{~cm} . K .163$. Opr. tekt. wspt.

„Ius canonicum ecclesiasticum Leapoldi Trybalski Ord. Praed., Sandomiriae $1846^{"}$.

Proweniencja: Klimontów.

Nr 103

1480. Łac. 1866 r. $21 \times 18 \mathrm{~cm}$. K. 184. Opr. bez okładek.

1. k. $1-55$. "Ius canonicum".

2. k. 56-142. "Tractatus theologicus de Incarnatione".

3. k. 142-184. "Tractatus de actibus humanis“.

Nota: „Ex manu scriptis Leopoldi Trybalski, 1866“.

Brak końca.

d) WYSOKIE KOEO

$\mathrm{Nr} 104$

668. Łac. 1686 r. $19 \times 16 \mathrm{~cm}$. K. 124. Opr. tekt. wspt. Skrypt szkolny z logiki.

1. k. 1-42. "Philosophia rationalis sive logica ad mentem S. Thomae - a P. Paschali a S. Rosa, scripta per F. Dominicum OPCLBer. ${ }^{116}$ in conventu Alterotensi".

2. k. 43-124. "Universa logica, 4 nov. $1686^{\text {“. }}$

Podpis: „F. Michaelis, lectoris philosophiae Opatoviensis mpp“.

e) $\mathrm{z}$ NIEUSTALONYCH SRODOWISK

$\mathrm{Nr} 105$

52. Łac. $X V$ w. $14,5 \times 10,5 \mathrm{~cm} . K .139$. Opr. deski bukowe w sk. wspl. nadniszczona.

Dzieła św. A 1 berta Wielkiego.

1. k. $1-39$. „De perfectione vitae spiritualis".

„Incipit liber Alberti Magni de adherendo Deo nudato intellectu et affectu. Et ultima et summa praescire X Atque nos custodiat Iesus Christus cum Patre et Spiritu Sancto in seculorum secula. Amen. Finitur iste Domini Alberti de nudato intellectu tractatus".

116 Litery te oznaczają: Ordo Praedicatorum Congregationis Sancti Ludovici Bertrandi. W' rękopisie "L" podobne jest do ,Z". Rozwiązanie tej trudności zawdzięczam o. Fabianowi Madurze z Krakowa. 
2. k. 39v-139. ,Tractatus de veris virtutibus (paradisus animae)". "Incipit domini Alberti tractatus de veris virtutibus, paradisus anime intitulatus. Rubrica. De caritate, de humilitate, de oboedientila ... Sunt quaedam vitia... X Contritio... Maledicti sint, qui declinant a mandatis".

Pismo jednej ręki. Inicjały i niektóre napisy czerwone lub niebieskie.

Skla dki: 12 seksternionów, w tym pierwszy i ostatni zdefektowane.

$\mathrm{Znaki}$ wo đne: 2 rodzaje fragmentów litery ", $\mathrm{P}^{\prime \prime}$.

Oprawa: deski bukowe, z przedniej okładki pozostal pasek $2,5 \mathrm{~cm}$ szeroki. Slady skóry obciągniętej i klamry mosiężnej do zamykania. Brak grzbietu.

Ręlkopis zmikrofilmowany w Bibliotece Narodowej w Warszawie, nr 17956.

Nr 106

614. Łac. $X V$ [?] w. perg. $28 \times 19 \mathrm{~cm} . K$. 237. Opr, deski w biatej skórze wspt.

"Summa theologica" św. Tomasza z Akwinu, część I.

K. 1. "Incipit prima pars summe fratris Thome de Aquino ordinis predicatorum, magistri theologie. Quia catholice veritatis doctor nor solum provectos debet instruere ... X ...(k. 232v) talis enim partus decebat eum qui est super omnia benedictus Deus in secula seculorum. Amen. Eplicit liber primus summe fratris Thome de Aquino ... Incipiunt tituli primi libri summe fratris Thome de Aquino ... (k. 237) utrum semen ... sit de superfluo alimenti".

Nieliczne glossy. Na k. 1 napis z XVIII w. „Prima pars summae D. Thomae ex revisione 1707 connotata“. Na k. 237 napis tą samą ręką: „Ex revisione connotata". Na wyklejce przedniej okladki napis olówkiem $z 2$ poł. XIX $w$. „Mss. XIII saec".

Pismo jednej ręki w dwu kolumnach. Tytừy i inicjały czerwone, rzadziej niebieskie.

$\mathrm{Sk} \nmid$ adki: 20 seksternionów, ostatni bez 3 kart.

O p r a wa: deski powleczone skórą gładką. 9 mosiężnych guzów ochronnych.

Na grzbiecie napis z XVIII w.: „Summa D. Thomae“. „117“.

Rękopis zmikrofilmowany w Bibliotece Narodowej w Warszawie.

Nr 107

77. Łac. XVIII w. $19 \times 14 \mathrm{~cm}$. K. 109. Opr. skóra biała tłocz. wspl. „Ex summa de exemplis aucthore Fr. Ioanne a Geminiano O. P." Wyjątki z dziela. Rejestr rzeczy.

Podpis: Robak.

Zachowana tylko część księgi.

\section{FRANCISZKANIE KONWENTUALNI}

KALISZ

Nr 108

766. Łac. 1 pot. XVIII w. $19 \times 16 \mathrm{~cm}$. K. 147. Opr. tekt. wspt. zniszczona.

1. k. 1-77. ,In XII Iibros Metaphysicae Aristotelis“.

2. k. 77--99. „In libros de generatione et cortruptione ... ad mentem Doctoris Subtilis".

3. k. 100-147. „Abdlank-Ursus seu Rawicz“. Objaśnienia herbów. 
Napis: Haec scripta sunt Fr. Josephi $B$ i e $r$ n a ck i ${ }^{117}$ regentis Calissiensis, definitoris Provinciae Ordinis Minorum Conventualium".

Nota proweniencyjna: „Dono cessit ab Ludovico Etting guardiano Cracoviensi A. D. 1732 mihi Francisco Kulczycki, franciscano".

\section{JEZUICI}

a) BRUNSBERGA

$\mathrm{Nr} 109$

759. Eac. $1720-1721$ r. $20,5 \times 16,5 \mathrm{~cm}$. K. 354. Opr. tekt. wspt.

Skrypty szkolne.

1. k. 1-275. „Umbra corporis naturalis in octo libros Aristotelis de philosophico auditu naturali philosopho affusa, avita Hosiani pedis mensura in cardinalitio Brunsbergensi collegii S. J. gymnasio mensurata a. 1720 die 22 martii".

2. k. 275-342. „Tractatus peripateticus in 3 libros Aristotelis De anima".

3. k. 343-354. "Tractatus philosophicus in Metaphysicam Aristotelis, finitus 6 iunii 1721". Spis rzeczy.

Napis: „Hic liber pro memoria donatus est a Severino Plucharz lectore s. theologiae Pragae mihi fr. Gerardo Wocedalski [?]“. „Ex libris P. Severini“.

b) JAROSEAW

$\mathrm{Nr} 110$

808. Eac. 1767 r. $22,5 \times 19 \mathrm{~cm} . K .178$. Opr. tekt. wspt.

Skrypty szkolne.

„Philosophia in scholis collegii Jaroslaviensis S. J. tradita per Stan. U r b ań s ki S. J.“

1. k. 1-42. "Logica - exercitationes logicae".

2. k. 43-178. „Dissertationes metaphysicae authore Stanislaro Urbański S. J., 8 octobris $1767^{\prime \prime}$.

c) KALISZ

\section{Nir 111}

719. Łac. 1715 r. $20 \times 16 \mathrm{~cm}$. K. 326. Opr. tekt. wspt.

Podręcznik szkolny. „Philosophia scholasticis disputationibus explicata a. D. 1715 per Alexandrum Pod l e s i e cki ${ }^{\mathbf{1 1 8}}$ Calissii".

1. k. 1-288. "De propositione, logica maior".

2. k. 289-326. "Logica minor seu dialectica“.

$\mathrm{Na}$ ostatniej karcie „Prophetia abbatis Andreoviensis Stanislai Rethiae de regibus Poloniae". oraz proroctwo św. Benedykta znalezione w Bibliotece Rzymskiej $1455 \mathrm{r}$.

Napis: „Ego Franciscus S. C. indui habitum spiritualem a. 1734 die 25 aprilis". Podpis późniejszy: L. Wiśniewski.

117 Estr. XIII 95.

118 Zył w 1. 1682-1762; inne jego dzieła podaje Estr. XXIV 409; por. W. W ą s ik: Historia filozofii polskiej. T. 1. Warszawa $1958 \mathrm{~s}, 74-75$. 
Nor 112

358. Eac. 1621-1659 r. $19 \times 15,5 \mathrm{~cm}$. S. 762, 12, 98. Opr. deski $w$ sk. $z$ ttoczonymi ornamentami rośl. $i$ herbami, wspt.

Zasady i wzory retoryki.

1. k. 1-762. "Orator Polonus inter praecepta rhetorica юrationum praxes, originem, eruditionem historicam ac symbolicam doctrinis politicis, ethicis, polemicis ex stemmatibus nobilitatis Polonae deductis illustratus in collegio archiepiscopali Karncoviano S. J. Calissiensi a. D. 1659. Index rhetoricus laudum".

2. k. 1-12. "Sententiae Taciti ex libris Annalium".

3. k. 1-98. "Praxis orationum" - mowy Sobieskiego, Krakowskiego, Ossolińskiego, Manieckiego, Zamojskiego, Leszczyńskiego, na pogrzebie Źółkiewskiego, Chodkiewicza, Koniecpolskiego; wzory mów okolicznościowych i przykłady z lat 1621-1658.

Proweniencja: Congr. Orat. Studziannae.

$\operatorname{Nin} 113$

259. Eac. 1701-1702 r. $14,5 \times 9$ cm. S. 391. Opr. deski $w$ sk. wspt. Podręcznik wymowy.

"Orrator Polonus sacer - politicus, id est senator et nobilis, iudex causidicus, miles, civis, rhetor scholasticus instructus Calissi a. D. 1701 et 1702 , series dicendorum".

Napis: „Hic liber applicatur Bibliothecae Radomiensi post pie defunctum Kamieński“".

d) KRAKOW

$\mathrm{Nor} 114$

148. Pol. $1729-1778$ r. $16,5 \times 11,5$ cm. S. 207, 372, 180. Opr. sk. czarna, wspl.

Notatki i uwagi z rekolekcji.

1. s. 1-207. „Rekolekcje dane od X. Antoniego S a mpław sk i eg o ${ }^{119}$ S. J. kaznodziei kolegium św. Piotra 1768 r. dn. 11 marca w konwencie naszym św. Andrzeja“".

2. s. $1-372$. „Rekolekcje dane od tegoż X. Sampławskiego r. 1770 d. 25 maja w konwencie naszym i opisane przez s. Karolinę Perłównę Z[akonu] S[więtej] M[atki] Klary córkę duchowną".

3. s. 1-43. "Rekolekcje dane na dni 10 od księdza Józefa Kob i elsk i e go ${ }^{120}$ "Soc. Jesu profesora $w$ kolegium św. Piotra na profesji mojej r. 1729 dnia 15 maja“.

4. s. 44-180. „Sposób zatrzymania ducha na ćwiczeniach duchownych zabranego d. 5 Iunii 1778 od X. Łuck i e go".

\section{Nrr 115}

787. Łac. 1689 r. $15 \times 9,5 \mathrm{~cm}$. K. 98. Opr. sk. żótta wspt. Wypisy z retoryki i zasady pisania listów.

1. k. 1-30. „Sententiae ex variis auctoribus collectae ac per al-

119 Por. ks. St. Za a ęski: Jezuici w Polsce. T. 3. Lwów 1902 s. 1053; Estr. XXXVII 58.

${ }_{120}$ Ży w latach 1693 - 2 VIII 1745; Estr. XIX 349; Ks. J. B rown: Biblioteka pisarzów asystencji polskiej Tow. Jez., Poznań 1862 s. 221. 
phabetum dispositae a proféssore rhetoricae Martino Jaźwiński S. J. Cracoviae $1689^{\prime \prime}$.

2. k. 33-98. „Liber de conscribendis epistolis“.

e) LUBLIN

Nir 116

749. Łac. pol., $1619-1620$ r. $19,5 \times 15,5$ cm. K. 340. Opr. sk. wspł.

Skrypty szkolne, kazanie i tezy z filozofii.

1. k. 1-103. ,In librum I et II Aristotelis De generatione finis impositus 6 nov. 1619".

2. k. 104-234. "In tres libros Aristotelis De anima“.

3. k. 235-333. ,In libros Metaphysices Aristotelis finis impositus a. 1620 die 23 iunii a P. Thoma Wron i a w ski professore".

4. k. 334-340. Kazanie na uroczystość św. Jana Chrzciciela.

5. Druk: „Conclusiones ex universa philosophia in coll. Lublinensi Soc. Jesu a Paulo Janczyński philosophiae auditore in collegio Lublinensi S. J. a. 1620. Cracoviae, typis Francisci Cesarii, 1620", k. 21. 21

Napis: „Bibliotheca Radom. Scholarum Piarum a Boguslao Wąsowicz officiali Radomiensi“.

\section{$\mathrm{Nr} 117$}

797. Eac. $1751-1769$ r. $20,5 \times 15,5 \mathrm{~cm}$. K. 858. Opr. sk. wspt.

Skrypty szkolne.

1. k. 1-28. „Institutiones philosophiae ... in scholis Lublinensibus S. J. a. 1764 ... per Carolum $E$ a s $\mathrm{ki}$ professorem nec non ab auditore Joanne Bapt. Stańkowski propugnatae". k. 1-62: „Logica“. k. 63-280: "Metaphysica per Carolum Easki Lublini 1767 die 16 ianuarii“. Wszyty druk: "Propositiones philosophicae propugnatae a. 1768 mense iunio". Podpis: „,ab Carolo Easki professore“.

2. k. 281-437. ,Institutiones philosophicae comparatae opera et studio Edmundi Purchotii Senonensis in iuris utriusque facultate licentiati, Universitatis Parisiensis antehac rectoris, tomus I complectens logicam et metaphysicam, Patavii 1751, typis apud Joannem Manfré".

3. k. 438-610. ,Metaphysica in scholis Jaroslaviensibus S. J. a. 1765 ab auditore Joanne B. Stańkowski propugnata“.

5. k. 626-709. „Tractatus de gratia Dei“. $1769^{\prime \prime}$.

6. k. $710-858$. „Tractatus de Incarnatione Verbi a 2 sept. 1768 in

Pismo kilku rąk.

Brak końca.

$\operatorname{Nir} 118$

590. Łac. $1752-1753$ r. $18 \times 11 \mathrm{~cm}$. K. 150. sk. wspt.

Skrypty szkolne.

1. k. 1-84. „Initium salutis ... Verbum caro factum est seu incar-

121 Druk nieznany Estreicherowi. Autor jego jest to zapewne ta sama osoba, którą E. wymienia $w$ opisie druku pt.: Threnodiae in funere Ill. D.D. Nicolai Christophori Radivili ... juventute studiosa Collegii Luccoviensis Societatis Jesu conscriptae. Typis Leopoliensibus. Estr. XXV 93. 
natio ... propugnata in Maciejoviano collegio Lublinensi S. J. anno 1752 in 1753 sub P. Ignatio Borow ski S. J.".

2. k. 86-150. "Tractatus de angelis, beatitudine et actibus humanis, explanatus in collegio Lublinensi S. J. a. 1752 in 1753 die 1 sept. a $\mathrm{P}$. Adamo Mikuł ow'ski S. J.“.

Napis: „Martinus Nazarewicz obtulit Bibliothecae Skarissoviensi 1789“.

$\mathrm{Nir} 119$

573. Łac. $1765-1766 r .20 \times 12 \mathrm{~cm}$. K. 131. Opr. tekt. wspt.

Skrypty szkolne.

1. k. 1-65. „Tractatus de gratia Dei et Christi ... in scholis Maciejovianis collegii Lublinensis S. J. propositus a die 1 sept. $1766^{\text {". }}$.

2. k. 69-131. ,Tractatus de virtutibus theologicis in scholis Maciejovianils collegi Lublinensis S. J. propositus a die 1 sept. $1766^{\circ}$.

\section{Nir 120}

370. Eac., pol. 1770 r. 19,5×15 cm. S. 587, 60. Opr. sk. wspt.

Teoria i historia wymowy.

1. k. 1-549. „Palatium Polonae libertatis Rempublicam oratoriam complectens, quod ex genio et proscripto eloquentiae a. 1670 erexit in collegio Lublinensi Soc. Jesu auctore Valentino P e n ski manu S.A.B.“

2. k. 550-565. "Summula dialecticae tradita Lublini a. 1670“.

3. k. 566-587. „Circulus palatii Iibertatis Polonae continens domesticam Reipublicae notitiam".

4. k. $1-60$ : "Differentia inter hierogliphica symbola et emblemata".

Proweniencja: „Ex libris Martini Jasiński canon. et parochi Sandom“.

$$
\text { f) } \mathrm{LWOW}
$$

$\mathrm{Nr}^{\prime \prime} 121$

578. Łac. $1749-1750$ r. 19,5×15,5 cm. K. 230. Opr. tekt. wspł.

Skrypty szkolne.

1. k. 1-112. "Tractatus de gratia divina, merito et peccatis in collegio Leopoliensi Soc. Jesu propugnatus, a. 1749 vergente in 1750 , ab ARP. Przanowski Mathia ${ }^{122}$ dictatus et scriptus per Adalbertum Dlugosz anni secundi theologiae m. p.".

2. k. 112-230. "Tractatus de sacramentis in scholis palatinis collegii Soc. Jesu a. D. 1749 in 1750 explanatus, ab P. Michaele O 1 o wsk i ${ }^{123}$ pomeridiano professore dictatus, per Adalbertum Dlugosz anni secundi theologiae scriptus m. p.".

\section{$\operatorname{Nr} 122$}

362. Eac., pol. $1642-1648$ r. $19 \times 15,5 \mathrm{~cm} . K$. 557. Opr. sk. wspt. Zasady retoryki i wiadomości heraldyczno.

1. k. 1-25. „Rhetor Polonus seu pars I quae continet praecepta rhetoricae ad usum nobilitatis iuventutisque Polonae accomodata in coll. Leop. Soc. Jesu anno 1642".

2. k. 26-408. "Orator Polonus seu pars II quae continet stemma-

122 Żyl w 1. 1703-1764; Z ałęs ki, jw. T. 3 s. 597, 650-652.

123 Inne dziela podaje Estr. XXIII 430. 
tum Polonicorum antiquitates et origines deinde super his usus orationum quosiam practicus universae nobilitatis Polonae ad actus publicos accomodatus".

3. k. 410-557. „Eruditionis antiquitatis symbola de gladio“. Dodany "Syllabus stemmatum“. $\mathrm{Na}$ marginesach rysunki herbów.

Podpis: „Istius libri possessor est Franciscus Casimirus Wilczek, eloquentiae auditor mpp. Rhetoricae istius professor fuit $\mathrm{P}$. Koloz warsi a. $1468^{\circ}$.

Nota: „Bilbiothecae Radom. Schol. Piarum accessit a. 1750, sub rectoratu P. Cypriani Małachowski“".

Nir 123

353. Eac., pol. $1725 \mathrm{r} .20 \times 16 \mathrm{~cm}, \mathrm{~K} .170$. Opr. tekt. wspt. zniszcz. Zasady wymowy.

"Rhetor in omni eloquentiae genere praeceptis exemplisque instructus in scholis Krosnovianis collegii Sieniaviani Leopoliensis Societ. Jesu a. 1725 die 30 sept".

g) OSTRÓG

$\operatorname{Nir} 124$

717. Eac. XVIII w. $20 \times 16 \mathrm{~cm} . K$. 337. Opr. tekt. wspt.

Skrypty szkolne. „Institutiones philosophicae selectiorum philosophorum sensui accomodatae".

1. k. 1-58. "Dialectica".

2. k. 59-113. "Logica in usum auditorum explanata".

3. k. 114-216. "Metaphysica in usum iuventutis scholasticae extradita".

4. k. 217-337. ,Institutiones physicae generalis in usum iuventutis scholasticae concinnatae a. $17 \ldots$ mense iunio in scholis ducalibus Ostrogiensibus Soc. Jesu".

Wycięto kilkanaście ostatnich kart.

h) PIOTRKow

Nir 125

757. Łac. $1771-1773$ r. 20,5X16,5 cm. S. 519. Opr. tekt. wspt.

Skrypt szkolny.

"Institutiones philosophicae ad usum candidatorum philosophiae studii eorum tempore quod biennio terminatur accomodatae per $P$. S w i e rczyńs ki ${ }^{124}$ Sloc. Jesu a. 1771 a die 3 octobris in scholis Petricoviensibus".

1. s. $1-34$. „Logica“.

2. s. 35-97. "Compendiaria metaphysicae institutio".

3. s. $98-127$. "Cosmologia".

4. s. $127-258$. "Psychologia".

5. s. 259-324. "Theologia naturalis".

6. s. $326-519$. „Physica generalis, triennalis cursus finitus a. 1773 die 2 iulii".

Na marginesie rysunki schematów ćwiczeń $z$ fizyki i z matematyki.

Proweniencja: Studzianna.

124 Enc. Now. XXVII 295 wspomina o Swierczyńskim Antonim T. J. żyjącym w latach $1671-1728$. 


\section{i) POZNAN}

$\mathrm{Nr} 126$

589. Łac. $1606 r .18,5 \times 14,5 \mathrm{~cm}$. K. 506. Opr. sk. wspt.

1. k. 1-330. „De sacramento poenitentiae“.

Skrypty szkolne.

"Disputationes de sacramentis".

2. k. 332-426. „De conversiore panis in corpus Christi“. Na k. 339 notatka: "Omnia quae sequuntur dictavit $\mathrm{P}$. Martinus $\mathbf{S} \mathrm{m}$ ig l e ck i ${ }^{125}$, quo tempore simul regebat collegium Posnaniense et vicem aegrotantis P. Vathaei B embus ${ }^{126}$ professoris ordinarii supplebat".

3. k. 427-440. "De sacramento extremae unctionis, 12 iunii 1606".

4. k. 443-506. "De sacramento matrimonii $i$.

Napis: Leopoli.

Brak ostatnich kart.

\section{Nrr 127}

532. Łac. 1609 r. $19,5 \times 15 \mathrm{~cm}$. K. 274. Opr. sk. wspt.

Skrypty szkolne.

1. k. 1-50. „D. Thomae quaestio XXIII de praedestinatione - sub Math. Bembi - - Martinus, Posnaniae 1609".

2. k. 50-61. „Disputatio de reprobatione, fr. Antonius Slupc. utitur - - excepta a Math. Bembi Soc. Jesu".

3. k. 62-183. „Ex I parte D. Thomae quaestio 26 de processu divinarum personarum".

4. k. 188-274. „Ex I parte D. Thomae quaestio L de substantia angelorum... excepta a Patre [Georgio] Tyszkiewicz ${ }^{127}$ S. J. prof. theologiae, Posnaniae 17 ianuarii $1609^{4 .}$.

Pismo różnych rąk.

$\mathrm{Nr} 128$

541. Łac. $1659-1660$ r. $19 \times 15 \mathrm{~cm}$. S. 357, 521. Opr. sk. wspt.

Skrypty szkolne. „Opus theologicum primi anni D. 1659 continens":

1. s. 1-357. "Disputationes in II-II D. Thomae De iustitia et iure sub P. Low ensztein ${ }^{127 a}$ a. 1659 et $1660^{\prime \prime}$. Spis rzeczy, na marginesie liczne objaśnienia łacińskie.

2. s. 1-407. „Tractatus de Deo secundum se spectato, P. [Thomas] M 1 odzi a n ow ski" 128. Liczne uwagi na marginesie.

Proweniencja: „Bibliothecae Congregationis Oratorii Studziannensis“.

1.25 Urodził się ok. r. 1560 zmarł w 1619 r.; Za lęski, jw. T. 2 s. 555; Enc. Now, 24-26; Es tr. XXVIII 304-316.

126 Zył w 1. 1567-1645; Enc. Now. II 121; Es tr. XII 456-461; H. H u r te r : Nomenclator litterarius recentioris theologiae catholicae. T. 1, fasc. 3/4. Oeniponte 1871 s. 787.

${ }_{127}$ Zył w 1. 1571-1625; Z ałęs ki, jw. T. 2 s. 686; Enc. Chełm. T. 39/40 s. 337.

127a Estreicher wymienia Teodora Lovensteina autora dzielka pt. Decas rationum quibus ecclesiae catholicae veritas, lutheranae vanitas demonstratur ... a Teodoro Lovensiein in Alma Acad. Crac. LL. studioso (Cracoviae 1636). W dedykacji hr. Denhoffowi autor mówi o swoim nawróceniu na katolicyzm. W pisaniu dzielka pomagał mu jezuita Marcin Becanus. Estr. XXI 421.

128 Ur. 21 XII 1622, zmarl 3 X 1686 w Krakowie; Enc. Now. XIV 454-456; Estr. XXII $452-457$; H urter. T. 2, fasc. $3 / 4$ s. 324 . 
Nir 129

542. Łac. XVII w. $20 \times 16,5 \mathrm{~cm} . K$. 381. Opr. sk. wspt.

Skrypty szkolne.

1. k. 1-129. „In Iam IIae partem S. Thomae Aq. de fine hominis, liber auscultationis theologicae consariptus a me Stanislaio Dobel sub P. Doctore theologiae M a s s u vio Posnaniae".

2. k. 130-381. „In III partem Divi Thomae commentarius Patris Dą browski Soc. Jesu theologi“.

\section{$\mathrm{Nr} 130$}

546. Łac. XVII w. $19 \times 16 \mathrm{~cm}$. K. 426 . Opr. tekt. wspt.

Skrypty szkolne.

1. k. 1-216. „In 2am 3ae Divi Thomae de fide, spe et charitate quaestiones sub Patre Tyszkiewicz, Martinus Słupecki, Posnaniae“.

2. k. 218-466, „In 3am partem Divi Thomae de sacramento poenitentiae, extremae unctionis, ordinis, matrimonii sub P. Thoma Massuvio S. Jesu professore".

Podpis: „Martinus Slupecki sub R, P. Tyszkiewicz Soc. Jesu“.

$\mathrm{Nr} 131$

1716. Łac. 1687 r. $19,5 \times 15,5 \mathrm{~cm}$. K. 264. Opr. sk. wspt.

Zasady poetyki, przykłady, sentencje i ćwiczenia.

"Aurifodina poetica seu ex fontibus castaliis derivata seu ex bicolli Parnaisso eruta in usum neo-poetarum Posnaniae a. 1687, Michael Zaleński sub Reverendo Magistro $\mathrm{Zubowski“.}$

Pismo różnych rąk.

Brak ostatniej karty.

Proweniencja: "Congr. Orat. Studziannae".

j) Puetusk

$\mathrm{Nr} 132$

593. Eac. 1601 r. $15,5 \times 10 \mathrm{~cm}$. K. 320. Opr. bez okladek wspt.

Podręcznik szkolny.

1. k. 1-133. „De iustificatione seu de meritis bonюrum operum, a. 1601 die 8 nov. Albertus Grusecki, Pultoviae".

2. k. 134-147. "Tractatus de cratione".

3. k. 147-182. "Disputatio de indulgentiis, Albertus Grusecki, Pultoviae finem scribendi imposui ultima iulii a. 1601".

Pisma wielu rąk.

Brak końca.

k) RESZEL

$\mathrm{Nr} 133$

440. Eac. 1727 r. $19,5 \times 16,5 \mathrm{~cm}$. K. 79 . Opr: tekt. wspt.

Skrypt wykładowcy. Zasady i wzory wymowy.

1. k. 1-41. „Aurora vitae ethico-politicae, eloquentia clarissimorum rhetorum praeceptis illustrata in Jagellonico Resseliensi Lycaeo S. J. a. D. 1727. Haec sunt, quae rhetores meos quoad orationes sacras instruendios duxi".

2. k. 41-79. „Tractatus de elocutione“.

Podpisy: Paszkiewicz, Doszowski. 
$\mathrm{Nr} 134$

443. Eac. 1733-1734 r. 19,5×16 cm. S. 112, 41. Opr. tekt. wspt.

Skrypty szkolne.

1. s. 1-112. „Regium iter ad coronam a regibus Alphonso et Carolo absolutum, nunc vero in regio Jegellonici collegii Resseliensis S. Jesu gymnasio monstratum a. $1733 \mathrm{~d}$. 7 sept. Haec rhetorica dictata est a Reverendo Magistro. Victore Przygodzki, scripta a me Mathia Josepho Kuczewski solutae eloquentiae auditore".

2. s. 1-41. „Campus floriduis in plano solutae eloquentiae intra periodlorum ambitu per locos dialecticos dimensus - - sedulae rhetorum culturae in regio Jagellonico collegio S. Jesu propositus ab anno 1734 die 3 septembris. Haec rhetorica dictata est a Reverendo P. H a r ras c h, scripta per me Mathiam Josephum Kuczewski“.

\section{$\mathrm{Nr} 135$}

397. Eac. 1 pot. XVIII w. $19 \times 15,5 \mathrm{~cm}$. K. 73 . Opr. tekt. wspt.

Skrypty szkolne. Materiały podyktowane słuchaczom wymowy.

1. k. 1-44. "Ceres regalis seu eruditiones sacro scholastico et civili statui accomodatae, ordine alphabetico in unum collectae, in subsidium utriusque eloquentiae neo-poesis in gymnasio Jagellonico Resseliensis collegii S. J. ad calamum traditae".

2. k. 45-73. "Argo comonata seu eruditae sententiae cuivis materiae deservientes e classicis auctoribus ordine alphabetico collectae atque neo-poetis in Jagellonico Resseliensi gymnasio Soc. Jesu ... ad calamum traditae. Haec eruditiones sententiaeque scriptae sunt in Poësi per me Mathiam Josephum Kuczewski, dictatae a Rev. Magistro Verner eiusdem classis professore".

\section{1) SANDOMIERZ}

$\mathrm{Nr} 136$

688. Łac. 1712-1713 r.19,5×16 cm. K. 406. Opr. tekt. wspt.

Skrypty szkolne.

1. k. 1-139. „Logica a. D. 1712 sub Patre [Matthia] Muchow$\mathrm{ski}^{129}$, Sandomiriae".

2. k. $140-311$. „Disputationes physicae, finitae a. D. 1713 die 30 ianuarii".

3. k. 312-406. „Disputationes metaphysicae, Sandomiriae. Hic liber scriptus a. D. 1712 et 1713 sub. P. Muchowski Soc. Jesu". $1722 "$.

Napis: „Ex libris Bartholomaei Nayrzałkiewicz ${ }^{130}$ parochi in Gliniany a. D.

$\mathrm{Nr} 137$

645. Eac. $1671-1673$ r. $19 \times 15,5 \mathrm{~cm}$. K. 273. Opr. sk. wspt.

Skrrypty szkolne.

1. k. 1-83. „Disputationes ad Ilam IIae Divi Thomae de iustitia et

129 Zmarł przed 1740 r.; Enc. Now. XV 271; Z a łęski, jw. T. 3 s. 1091; Estr. XXII 619 .

${ }_{180}$ Ks. J. Wiśniewski (Monografie kośçiołów w dekanacie opatowskim, Radom 1907 s. 176) podaje listę proboszczów $w$ Glinianach dopiero od r. 1797. 
iure, collegium Sandomiriense Soc. Jesu, Patris Joannis Hos t y ń s k i ${ }^{131}$, $1671^{\prime \prime}$.

2. k. 84-189. „Tractatus de Deo-Homine ad IIIam partem Divi Thomae De incarnatione, Patris Joannis Hostyński, 1672".

3. k. 190-273. „Disputationes in III partem Divi Thomae De sacramentis, Patris Joannis Hostyński, 1673“.

Brak końcowych kart.

$\mathrm{Nr} 138$

651. Eac. 1711-1712 r. $20,5 \times 16,5 \mathrm{~cm}$. K. 215. Opr. wspt., zniszcz.

Skrypty szkolne. "Tractatus ex theologia morali".

1. k. 1-58. „De censuris... sub Patre Martino $R$ udolski a. 1711 die 30 iunii continuatum, per me Martinum Jasiński scriptum".

2. k. 59-135. „De contractibus et restitutione, finitum sub Patre Paulo Perkiewicz 1712 die 27 iunii et per me Martinum Jasiński scriptum".

3. k. $137-215$. „De matrimonio".

Proweniencja: „Ex libris Martini Jasiński canonici, parochi Sandomiriensis“.

$\mathrm{Nr} 139$

610. Eac. 1 pot. XVIII $w .19,5 \times 15,5 \mathrm{~cm} . K .316$. Opr. perg. $z$ tekstem biblijnym $z X V \quad w$. , wspt.

Skirypty szkolne.

1. k. $1-180$. "Tractatus de actibus humanis, de regula tam interna quam externa scilicet conscientia, praeceptis, legibus et aliis huc spectantibus ac reducibilibus". Podpis: Stanislaus Giuźwicz [?].

2. k. 185-312. "Tractatus de censuris et irregularitate“.

3. k. 313-316. "Tractatus de contractibus licitis et de contractu illicito seu usura“". Nie dokłończony.

Po pierwszym i drugim traktacie napis: „Ex libris Martini Jasiński can. et par. Sand.".

$\mathrm{Nr} 140$

99. Pol. XVII w. $13 \times 8 \mathrm{~cm}$. K. 94. Opr. tekt. wspt.

„Nabożne westchnienia pragnącej Boga duszy, trojakiemu stanowi służące, których abrazy Ermana. U g on a opisane i przetłumaczone".

Podpis: zakonnica R[eguly] S[więtego] O[jca] B[enedykia].

$\mathrm{Nr} 141$

116. Pol. 1710-1713 r. $19,5 \times 15,5$ cm. K. 180. Opr. sk. wspl.

Notatki z rekolekcji.

1. k. 1-64. „Kolekcje albo dziesięciodniowa $z$ Bogiem zabawa duszom świętym zakonnym dana przez ks. Romualda $R$ adeckiego S. J. roku $1710^{\prime \prime}$.

2. k. 65-163. "Kolekcje dla dusz świętych zakonnych przez X. Bazylego N a rbotha ${ }^{132}$ S. J."

3. k. 164-180. „Refleksje podczas kolekcji dane przez P. W. X. J. W. S. J. K. S. O. 1713 r. dnia 11 maja“.

Pismo wielu rąk.

131 Żył w 1. 1630 - 12 III 1685; Estr. XVIII 297.

132 Zyl w l. 1663 - 6 I 1722; Es tr. XXIII 38.

Archiwa, Biblioteki i Muzea Kościelne - T. 4. 
Napis: „Te książki są teraz Marianny Moszyński po śmierci P.C. A. Dembińskiej dane“.

Podpis: Panny Lębieńskiej MMI ZROSB.

$\mathrm{Nr} 142$

227. Pol. 1758 r. $18,5 \times 14,5 \mathrm{~cm}$. S. 8. Opr. luźne kartki.

„Litania $w$ utrapieniu lub chorobie będących, 5 maja 1758 od Ojca Mikołaja J uśkiew i c z a ${ }^{133}$ S. J. dana i przepisana“.

$\mathrm{Nr} 143$

113. Pol. $X V I I I$ w. $19 \times 15,5 \mathrm{~cm} . K .59$. Opr. tekt. wspt.

„Zegar duchowny, tj. ośmiodniowe ducha kolekcje od św. Ignacego podane św. Benedykta zakionowi panieńskiemu w klasztorze sandornierskim".

Napis: „Przewielebnej w Bogu Jmci Pannie Krzewskiey“.

\section{$\mathrm{Nr} 144$}

115. Pol. XVIII w. $19 \times 16 \mathrm{~cm}$. K. 67. Opr. tekt. wspt.

"Zegar duchowny, tj. ośmiodniowe kolekcje od św. Ignacego podane, św. Benedykta zakonowi panieńskiemu $w$ klasztorze sandomierskim ofiarowaine".

Pismo różnych rąk.

Napis: „Przewielebnej w Bogu Jmci Pannia Wolski. X. Kokoszyńskiego. Sniżyńskiego".

$$
\mathrm{Nr} 14 \dot{5}^{\circ}
$$

301. Pol. XVIII w. $30,5 \times 19,5 \mathrm{~cm}$. K. 12. Opr. tekt. wspt.

„Przybytek, który umierając dla Boga św. Placyd męczennik i opat przynosi niebu, Kościołowi, zakonowi św. Benedykta od kapłana Societatis Jesu. Przemowa do panien zakonnych pod regułą św. Benedykta klasztoru sandomierskiego ".

\section{$\operatorname{Nr} 146$}

1503. Eac. 1706 r. $20 \times 17 \mathrm{~cm}$. K. 193. Opr. tekt. wspt. zniszczona.

Skrypty szkolne.

1. k. 1-41. „Aliqua de iure canonica: de consecratione ecclesiae vel altaris".

2. k. 43-100. „De censuris et aliis ecclesiasticis poenis tractatus theologicus" .

3. k. 103-193. „Decisiones - - ex libro IV et V Decretalium - a. 1706 in collegio Gostomiano S. J. dictante P. Ignatio G $10 \mathrm{w}$ a c k i“* ${ }^{134}$

Proweniencja: „Ex libris Martini Jasiński canon. et parochi San“.

$\mathrm{Nr} 147$

1487. Eac. $1710-1712$ r. $21 \times 17 \mathrm{~cm}$. K. 293. Opr. telt. wspt. zniszcz. Skrypty szkolne.

1. k. 1-19. "Summulae casuum".

2. k. 21-107. "Jasiński Martinus, sub Jacobo B eth $\mathrm{m}^{\text {a }{ }^{135}}$ scriptum ius canonicum. Liber V Decretalium. 1710-1711“.

\footnotetext{
183 Żył w 1. 1691 - 11 III 1762; Estr. XVIII 688.

134 Ży w l. $1667-26$ VI 1729; Estr. XVII 190-191.

135 Estr. XII 527 .
} 
3. k. 109-206. „Jasiński Martinus notavit dictante P. Josepho Andrzejow icz ${ }^{136}$. Praelectiones in librum I Decretalium".

4. k. 208-293. „Jasiński Martinus scripsit sub P. Ignatio Gluwacki. Quaestiones canonicae in II librum Decretalium. 1712“".

$\mathrm{Nr} 148$

1590. Eac., pol. 1735 r. $15,5 \times 10 \mathrm{~cm}$. S. 267. Opr. sk. wspt.

„Libellus benedictionum variarum Sandomiriae a. D. 1735 die 1 ianuarii conscriptus".

$\mathrm{Nr} 149$

411. Łac., pol. $1716-1717$ r. 15,5×9,5 cm. K. 12. Opr. brosz. wspt. Skrypt szkolny.

„Campus eloquentiae scholasticae ad orbitam Gostomianae fasciae - apertus in collegio Gostomiano Soc. Jesu ex a. 1716 in a. 1717 sub P. Xaverio Brzeski professore".

Proweniencja: „Ex libris Nicolai Zajączkiewicz manu propria scriptus“.

$\mathrm{Nr} 150$

409. Łac. $1716-1717 r .15,5 \times 10 \mathrm{~cm}$. K. 48. Opr. brosz. wspt.

Skrypt szkolny.

„Orator politicus ad triplicem stylum patrium eloquentiae candidatos manu ducens ex a. 1716 in a. 1717 sub P. Xaverio Brzeski professore scholae rhetroricae".

\section{Nr 151}

412. Łac. 1717 r. $15,5 \times 10 \mathrm{~cm}$. K. 9. Opr. brosz. wspt.

Wzory mów. „Orator - - dziękujący - - winszujący - aplaudujący, kondolencję świadczący $w$ kolegium sęndomirskim Soc. Jesu wydany 1717 r. ánia 28 maja".

$\mathrm{Nr} 152$

413. Łac. 1717 r. 15,5×10 cm. K. 10. Opr. brosz. wspt.

Wzory mów. „Altum eloquentiae ad gentilitia Sandomiriensis Palatinatus flumina nobilissimis huius artis candidatis demonstratus a. 1717 die 22 septembris".

$\mathrm{Nr} 153$

407. Eac. 1697 r. $14 \times 9 \mathrm{~cm}$. K. 55. Opr. brosz. wspt.

Zasady poetyki. Skrypt wikolny. instructus, in collegio S. J. Gostomiano _- propositus Sandomiriae a. D. 1697 “.

Proweniencja: „Ex libris Martini Jasiński canonici et parochi Sandomiriensis“.

$\mathrm{Nr} 154$

1701. Eac., pol. 1730-1731 r. S. 154. Opr. tekt. wspt.

Zasady poetyki. Skrypt szkolny.

1. s. 1 -132. „Fides poetica nervosis praeceptionibus instructa - -

${ }_{136} \mathrm{Za} \mathrm{lęski,} \mathrm{jw.} \mathrm{T.} 4$ s. $322,371,473 ;$ Estr. XII 157. 
in Gostomiano Orbe Palatinatus Sandomiriensis a. 1730 die 7 octobris in a. 1731 promulgata. Stanislaus Haraczkiewicz".

2. s. 141-154. "De tropis“.

Podpis: Michael Jakubowski.

$\mathrm{Nr} 155$

753. Eac., pol. 1705 r. $19 \times 15,5$ cm. S. 32. Opr. brosz. wspt.

Skrypt szkolny z gramatyki.

„Liber exercitiorum polono-latinorum, traditus a magistro Francisco $\mathrm{Pl} \mathrm{u}$ c ie ń s k i ${ }^{137}$ eiusdem scholae grammaticae professore, scriptusı vero per me Martinum Jasiński eiusdem scholae alumnum 1705 die 16 aprilis".

Brak końcowych kart.

Proweniencja: klasztor dominikanów w Klimontowie.

k) SZOTLAND

Nr 156

770. Eac. 1738 r. $20 \times 17 \mathrm{~cm}$. K. 238. Opr. bez oktadek wspt.

Skrypty szkolne.

1. k. 1-41. „Logica minior seu dialectica explanata in collegio Rozrażeviano Soc. Jesu ${ }^{138}$ anno 1738 d. 9 sept., finitum die 10 octobris".

2. k. 42-238. „Scientia rationalis seu logica“.

Brak końcowych kart.

m) TYRNAWA

$\mathrm{Nr} 157$

799. Eac. 1740 r. $21 \times 16,5 \mathrm{~cm}$. K. 118. Opr. tekt. wspt.

Skrypt szkolny.

"Tractatus in universam Aristotelis Logicam, scriptus sub Patre Joanne Bapt. $\mathrm{H}$ a vi ior S. J. per me Georgium Jarbss collegii generalis cleri r[egulae] h[uius] alumnum die 7 septembris 1740 , Tyrnaviae".

$\mathrm{Nr} 158$

550. Łac. 1669 r. $20 \times 15,5 \mathrm{~cm}$. K. 33, 42, 87. Opr. tekt. wspt. Skrypty szkolne.

1. k. 1-33. „Tractatus: de angelis consummatus 12 martii 1669, de Incarnatione". Z wykładów Ladislai S e nniey S. J. spisał Felicianus Guarient, 1669, Tyrnaviae.

2. k. 1-42. „De actibus humanis, consummatus die 17 augusti 1669 Tyrnaviae. Haec materiae auditae sunt ab P. Ladislao Senniey e Societate Jesu artium et philosophiae nec non s. theologiae doctore eisdemque professore ordinario, consriptae vero a fratre Feliciano Guarient $\mathrm{O}$ [rdinis] S[ancti] P[auli] P[rimi] E[remitae] professo“.

3. k. $1-87$. „De Incarnatione, 1669, Tyrnaviae".

Proweniencja: $\mathrm{z}$ kościoła popaulińskiego $\mathrm{w}$ Beszowej oddano do Biblioteki Seminarium Duch. w Sandomierzu w $1931 \mathrm{r}$.

137 Zmarł w czerweu 1723 r.; Estr. XXIV 366-372.

138 Szotland pod Gdańskiem; Ks. S. Chodyński: Seminarium włocławskie. Whoclawek 1904 s. $318-334$. 
n) WARSZAWA

$\mathrm{Nr} 159$

738. Łac. 1685 r. $21 \times 17 \mathrm{~cm}$. K. 309. Opr. bez okładek wspl.

Poodręcznik szkolny.

1. k. 1-298. „Philosophia naturalis seu physica - editio P. [Georgii] Stanisławski prof. in collegio Varsaviensi S. J." 138a

2. k. 299-309. ,Metaphysica seu philosophia transcendentalis - editio philosophiae huius Patris G. S ta $\mathrm{n}$ is 1 a w s ki, ordinarii professoris in collegio Varsaviensi Soc. Jesu $1685^{6 "}$.

$\mathrm{Nr} 160$

735. Eac. 1707 r. $19,5 \times 16 \mathrm{~cm}$. K. 206. Opr. tekt. wspt.

Podrecznik szkolny.

1. k. 1-70. „Clavis scientiarum - dialectica tradita philosophis Collegii Varsaviensis Soc. Jesu a. 1707, finitus labor die 7 decembris a. 1707“.

2. k. 71-206. "Philosophia rationalis seu in Organum Aristotelis disputationes".

$\operatorname{Nr} 161$

655. Łac. 1712 r. $19 \times 15,5 \mathrm{~cm}$. K. 232. Opr. bez okładek wspt.

Notatki z logiki, przykłady i reguły wymowy.

1. k. 1-22. "Loigica“.

2. k. 73-232. "Consiliarii principum - - in ore gladii Hectores - Jagellonico rhetoricis pallaestritis collegio Varsaviiensi Soc. J. a. $1712^{\prime \prime}$.

Proweniencja: Klimontów.

$\mathrm{Nr} 162$

544. Eac. $1687-1689$ r. $19 \times 15 \mathrm{~cm} . K$. 211. Opr. sk. wspt. zniszcz. Skrypt szkolny.

„Tractatus theologicus in I partem Summae D. Thomae Aq. de Deo uno et trino per Nicolaum Narmunth a. D. 1687 a Calendis Septembris ad Calendas Iulii 1688 conscriptus Varsaviae in collegio Soc. Jesu sub P. [Ioanne] D r e w s ${ }^{139}$ s. theol. doctore et denunc ordinario professore". $\mathrm{Na}$ k. $211 \mathrm{v}$ notatka o spaleniu w Warszawie pism ateistyczinych Jana Kazimierza Eyszczyńskilego i jego samego 30 III 1689. ${ }^{140}$

Podpis: Fr. Albericus m.ppa.

Proweniencja: kościól parafialny w Skrzynnie.

$\mathrm{Nr} 163$

531. Eac. 1690 r. $20 \times 16 \mathrm{~cm}$. K. 307. Opr. tekt. wspt.

Skrypty szkolne.

1. k. 1-154. „Tractatus theologicus in III partem Summae Thomate De sacramento paenitentiae et matrimonii - traditus in collegio Varsaviensi Soc. Jesu a. D. 1690 ".

2. k. 155-307. "Tractatus theologicus de fide, spe et caritate".

138a W 1, 1684-85 profesorem logiki i metafizyki w kolegium domu warszawskiego był Jerzy Stanisławski. Bibl. Uniw. KUL rps 206 k. 163, 167v. Zmarł 13 VII 1689 w Wilnie. Tamże k. $368 \mathrm{v}$.

130 Żyl w 1. 1645-1710; Z a lęs ki, jw. T. 3 s. 1110; Enc, Now. IV 339.

140 Bibliografię podaje Estr. XXI 549. 
$\mathrm{Nr} 164$

501. Łac. 1691 r. $19,5 \times 15,5 \mathrm{~cm}$. K. 169. Opr. tekt. wspt.

Skrypty szkolne.

1. k. 1-101. ,Tractatus polemicus de iudice controversiarum fidei, traditus in collegio Varsaviensi Soc. Jesu a. D. 1691 ab Patre Nicolao $\mathrm{Narmunt} \mathrm{h}^{\text {" }} 141$.

2. k. 102-169. „Theologia positiva - dominicla Quadragesimae explanatio in Ecclesiasticum".

Pismo wielu rąk.

$$
\mathrm{Nr} 165
$$

554. Eac. 1691 r. $20 \times 16 \mathrm{~cm}$. K. 374. Opr. tekt. wspt.

Skrypty szkolne.

1. k. 1-188. "Tractatus theologicus in primam partem Summae D. Thomae Aquinatis in collegio Varsaviensi Societ. Jesu per P. Nicolaum Narmunth traditus $1691^{\text {“. }}$

2. $k .189-374$. "Tractatus theologicus in secundam secundae D. Thomae Aquinatis De iure et iustitia, in collegio Varsaviensi Soc. Jesu a. D. 1691 traditus per Joannem Drews".

\section{$\mathrm{Nr} 166$}

547. Łac. 1693 r. $20 \times 16,5 \mathrm{~cm} . K_{\text {: }}$ 523. Opr. tekt. wspt.

Podręczniki szkolne.

1. k. 1-240. "Tractatus theologicus de peccatis et gratia, per P. Christophorum $€$ os ie w s'k i ${ }^{142}$ a. 1693 in coll. Varsav. Soc. J. traditus".

2. k. 242-523. ,Tractatus theologico-scholasticus in III Divi Thomae partem De sacramentis a quaest. 60 et deinceps authore Patre Kir-

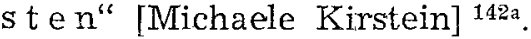

Pismo wielu rąk.

$$
\mathrm{Nr} 167
$$

513. Łac. 1696 r. $18,5 \times 15,5 \mathrm{~cm}$. K. 196. tekt. wspt. zniszcz.

Skrypty szkolne.

1. k. 1-101. „Christus Deus-Homo. Tractatus theologicus in III partem D. Thomae Aq. De Verbo Incarnato explicatus in coll. Varsaviensi Soc. Jesu a. D. 1696 per Stanislaum $€$ os i e w s k i ${ }^{143}$, lectio matutina “.

2. k. 102-196. "Tractatus De angelis, beatitudine et actibus humanis a. D. 1696, lectio pomeridiania per Patrem Kirsten tradita“.

\section{$\mathrm{Nr} 168$}

510. Łac. 1697 r. $18,5 \times 15 \mathrm{~cm}$. K. 191. Opr. tekt. wspt.

Skrypty szkolne.

1. k. 1-96. „Dei-Hominis Christi sapientia seu tractatus theol. in 3. partem Divi Thomae De sacramentis, 1697 lectio pomeridiana P. Stanislai Łosiewski S. J. in coll. Vars."

t41 Z a łęski, jw. T. 3 s. 893

14: Estr. XXI $413-416$.

142 W 1. 1692-1697 notowany jako profesor teologii scholastycznej kolegium domu warszawskiego. Bibl. Uniw. KUL rps $206 \mathrm{k} .197 \mathrm{v}, 201 \mathrm{v}, 206,209 \mathrm{v}, 213 \mathrm{v}$, 219. Zmarł 7 VI $1705 \mathrm{w}$ Pińsku. Tamże k. 371v.

143 Estr. XXI 416. 
2. k. 97-191. ,Tractatus theol. de peccatis et gratia, a D. 1697 lectio matutina Patris Kirsztejn".

$$
\text { Nr } 169
$$

540. Łac. 1699 r. $20 \times 16,5$ cm. K. 215. Opr. tekt. wspt. zniszcz.

Skrypty szkolne.

1. k. 1-137. „Deus trinus et unus disputationibus theologicis explanatus in collegio Varsaviensi Soc. Jesu a. D. 1699 die 2 sept. per Patrem Stanislaium Eosiewski, lectio pomeridiana“.

2. k. 139-215. ,Tractatus theologicus de virtute iustitiae per Patrem Abrah[am] D y m s ze w i c z ${ }^{144}$, lectio antemeridiana“.

Proweniencja: kościół w Skrzynnie.

\section{Nr 170}

647. Eac. 1698 r. $20 \times 16 \mathrm{~cm}$. S. 207, 194. Opr. tekt. wspt.

Skrypty szkolne.

1. s. $1-207$. "Ministerium reconciliationis seu tractatus theologicus de paenitentia, in coll. Vars. S. J. 1698 die 1 sept. per P. Stanisl. Łosiewski traditus, lectio matutina".

2. s. 1-194. "Tractatus theologicus de virtibus theologicis, lectio pomeridiana Patris $\mathrm{N}$ a re $\mathrm{W}$ i c z" $\mathrm{z}^{144 a}$.

Froweniencja: kościół w Skrzynnie.

\section{$\mathrm{Nr} 171$}

1478. Łac. 1693 r. $20 \times 16 \mathrm{~cm}$. S. 451 . Opr. tekt. wspt. nadniszcz.

Skrypt szkolny z komentarzem na Dekretaly.

S. 1-121: „Liber IV Decretalium“. s. 122-164: „Liber I Decretalium“. s. 167-234: „Liber II Decretalium“. s. 236-35̄5: „Tractatus de desponsatione impuberum, de processu iudiciario, praelectiones canonisticae in $V$ librum Decretalium, de vita et statu clericorum in titulos aliquos libri III Decretalium a. 1693 per Christophorum Eosiewski Soc. Jesu in collegio Varsaviensi traditus". s. 360-400: "Tractatus canonicus de beneficiis ecclesiasticis". s. 402-451: "Tractatus iuridico-canonicus de vita et honestate clericorum".

\section{o) WILNO}

\section{$\mathrm{Nr} 172$}

587. Łac. 1600 r. $19,5 \times 15,5 \mathrm{~cm} . K .177,111$. Opr. sk. wspł. Skrypty szkolne.

1. k. 1-177. "Tractatus de Deo a P. Martino Śmiglecio ${ }^{145} \mathrm{~s}$. theologiae doctore, 17 ianuarii 1600 ".

2. k. $1-60$. "De angelis a P. Hieronymb $\mathrm{Stef}$ a now skite $\mathrm{s}$. theologiae professore a. 1600 die 18 februarii“.

3. k. $61-111$. „Commentarii in bipartitam Summae theologicae par-

144 Estr. XV 436.

144a Andrzeja Narewicza wymienia Estreicher jako tego, który podpisał dedykację wydania jezuickiego (Wilno 1706) dzielka Samuela ze Skrzypny Twardowskiego pt. Przeważna legacja J. O. Książecia Krzyszłofa Zbaraskiego... do... cesarza tureckiego Mustafy w roku 1621. Estr. XXXI 436.

145 Urodzony ok. r. 1560, zmarl w 1619 r.; Estr. XXVIII 304-316.

140 ŻI w 1. 1567-1606; Enc. Now. XXVI 543; Estr. XXIX 272-273. 
tem secundum S. Thomam Aq. inchoantur Vilnae a. 1600 , de beatitudine hominis a P. Hieronimo Stefanowski in Academia Vilnensi Soc. Jesu, scripti per me f. Andream Rochmannium ${ }^{147}$ Ord. Minorum de Observantia“.

Na marginesie objaśnienia lacińskie.

Proweniencja: „Ex libris F. Ord. Min. de Obser.“

$\mathrm{Nr} 173$

1712. Łac. 1614-1619 r. $19 \times 15 \mathrm{~cm}$. S. 571. Opr. sk. wspt. tłoczony herb jezuitów $i$ napis "Reth. Lib. And. Bud. a. D. 1619“.

Skrypty szkolne $\mathrm{z}$ retoryki.

1. s. 1-467. "Commentarius in IV libros Rhetoricorum M. T. Ciceronis, a reverendo magistro Gordiano Protaszewicz, tunc in Academia Vilnensi professore praefatus, scriptus per me Andream Budziński studiosum rhetorices s. D. 1614".

2. s. $470-571$. „Normae sive regulae exercitiorum nonnullorum rhetcricae".

Proweniencja: „Hunc librum donavit Nicolaus Radomowski curatus Telszensis bibliothecae Radom. collegii Scholarum Piarum".

$\mathrm{Nr} 174$

755. Eac. 1616 r. $18,5 \times 15,5 \mathrm{~cm}$. K. 376. Opr. sk. wspt.

Skrypty szkolne.

1. k. 1-38. „In M. T. Ciceronis libnos de Oratore ad Q. fratirem commentarius. Haec dicta sufficiunt a. D. 1616 die 23 iulii".

2. k. 39-376. "Compendium totius logicae a. D. 1616 in Alma Academia Vilnensi Soc. Jesu traditum a P. Jacobo O $1 \mathrm{szewski}{ }^{148}$ professore philosophiae".

\section{p) WROCEAW}

Nrr 175

758. Eac. $1675-1720$ r. $18 \times 14,5 \mathrm{~cm}$. S. 75, 376, 476, 406. Opr. tekt. wspt.

Skrypty szkolne. „Universa philosophia Peripatetica, tradita a P. Joanne Paczyntzky, conscripta vero ab eiusdem auditore in Universitate Wratislaviensi Francisco Walter Silesio Leobschiecensi a. 1720".

1. s. 1-75. "Tractatus dialecticus".

2. s. $1-376$. "Quinque tractatus logici“.

3. S. 1-476. "Tractatus physici in VIII libros Aristotelis de physico auditu, 7 septembris $1675^{6}$.

4. s. 1-406. "Tractatus in libros Aristotelis de coelo et de anima".

Napis: „Ego P. Joachimus pro usu conventus Radomiensis applicavi a. 1723“.

Nota: "Nunc vero die 6 maii a. 1769 ad provinciam Minoris Poloniae per P. Severinum Szober Silesium dono data, qui protunc lector fuisse philosophiae in conventu Paradisiensi ad Jesum Coronatum ad tertium annum".

$\mathrm{Nr} 176$

658. Łac. $1726-1727$ r. $20,5 \times 16,5 \mathrm{~cm}$. K. 206. Opr. tekt. wspt.

147 Estr. XXVI 321 .

148 zyl w 1. 1585 - 5 VI 1634; Z a 1 ęs ki, jw. T. 2 s. 671 n; Enc. Now. XVII 275; Estr. XXIII $336-339$. 
Skrypt szkolny. Tezy do egzaminu przed otrzymaniem stopnia bakałar"za.

„Disputationum Peripateticarum conclusiones pro baccalaureatu. Pars I sive philosophia rationalis, tradita a Patre Francisco $\mathrm{H}$ y $\mathrm{p}$ is $\mathrm{ch}$ Soc. Jesu, artium licentiatum et philosophiae doctorem, in alma caesarea regiaque Universitate Leopoldina Wratislaviae professore publico ac ordinario, conscripta a Sigismundo Wohlweber eiusdem philosophiae auditore a. 1726 vergente in a. $1727^{\prime}$. Na k. 206 dodano 20 ,conclusiones pro baccalaureatu".

Nota: „In simplicem usum Patris Lucae Rösner Ord. Minor. S. Francisci vicarii actualis a. 1790 “.

Proweniencja: Conventus Radomiensis PP. Bernardinorum.

Nr 177

720. Eac. 1727-1728 r. $20,5 \times 16 \mathrm{~cm}$. K. 321. Opr. tekt. wspt. Skirypt szkolny.

„Disputationum Peripateticarum pars II sive philosophia naturalis, tradita a Patre Francisco Hypisch S. J., in Universitate Leopoldina Wratislaviensi philosiophiae professore publico ac ordinaria, conscripta a Sigismundo Wohlweber eiusdem auditore a. 1727 vergente in a. $1723^{\prime \prime}$. $\mathrm{Na}$ ostatnich kartach 57 ,conclusiones pro magisterio philosophiae".

Proweniencja: Conventus Radomiensis PP. Bernardinorum.

\section{$\mathrm{Nr} 178$}

657. Łac. XVIII w. $19,5 \times 14,5 \mathrm{~cm}$. K. 178. Opr. tekt. wspt.

Skrypt szkolny.

"Cursus philosophicus tribus partibus distinctus, universam Aristotelis logicam, physiclam et metaphysicam explicans ... a P. Francisco Fragste in Soc. Jesu, artium licentiato et philosophiae doctore eiusdemque professore publico et ordinario traditus".

$\mathrm{Nr} 179$

619. Łac. $1702-1703$ r. $19,5 \times 16,5$ cm. S. 656. Opr. sk. wspt.

Skrypty szkolne.

1. s. 1-583. "Tractatus theologico-moralis de poenitentia et matrimonio sub. P. Michaele $\mathrm{Rh}$ e $\mathrm{nn}$ iok $\mathrm{S}$.J. ordinario theologiae professore traiditus a. $1703^{\prime \prime}$.

2. s. 603-656. "Resolutiones casuum anni 1702 et 1703 “.

Proweniencja: Klimontów.

r) Z NIEUSTALONYCH SRODOWISK

$\mathrm{Nr} 180$

669. Łac. 1672 r. $20 \times 16 \mathrm{~cm}, K .250 .0 p r . s k, w s p t$. zniszcz.

Podręcznik szkiolny. $1726^{\prime \prime}$.

„Dialectica et logica a Patre Martino Grymosz ${ }^{149}$ S. J. edita a.

149 Zył w 1. 1633 - 9 VIII 1708; Z a łęs ki, jw, T, 3 s, 1113; Enc. Now. VI 442 ; Estr. XVII $434-436$. 


\section{$\mathrm{Nr} 181$}

792. Łac. 1672-1674 r. $19 \times 16 \mathrm{~cm}$. K. 485. Opr. bez okładek wspt. Skrypty szkolne.

1. k. 1-31. "Quaestiuneulae institutionum dialecticarum a. D. 1672".

2. k. 32-174. "Quaestiones logicae".

3. k: 175-407. QQuaestiones physicae in Physicam Aristotelis a P. Paulo Ko: st a n e cki ${ }^{150}$ S. J.".

4. k. 409-485. "Quaestiones metaphysicae a. D. 1674“.

\section{$\mathrm{Nr} 182$}

677. Eac. 1693-1695 r. $20 \times 16 \mathrm{~cm}$. K. 183. Opr. bez. okt.

Skrypty szkolne.

1. k. $1-69$. "Metaphysica a. D. 1695 die 1 sept.“.

2. k. 70-103. "Summa ethicae". 1694 ".

3. k, 103-104. „Mathesis succincta ... sub P. Głaże wicz a.

4. k. 144-183. „Dialectica proposita auditoribus rhetorices 1693, 1 iunii".

Rysunki geometryczne na marginesie.

Rękopis zniszczony przez kamnika.

\section{Nr 183}

687. Łac. 1693 r. $20 \times 16 \mathrm{~cm}$. S. 764. Opr. bez okt. wspt.

Skrypty szkolne. „Philosophia scholastica quaestionibus illustrata ab Patre [Martino] $\mathrm{Dz}$ i e wa $\mathrm{n} \bullet \mathrm{wski}^{151}$, docto viro et religiosissimo a. D. $1693^{\prime \prime}$.

1. s. 1-111. „Dialectica“.

2. s. $11-764$. "Logica a. 1693 die 7 octobris".

Proweniencja: kościół w Skrzynnie.

\section{$\mathrm{Nr} 184$}

729. Eac. 1702 r. $19 \times 15,5 \mathrm{~cm}$. K. 434. Opr. tekt. wspt. zniszczona. Skrypty szkolne.

1. k. 7-147. "Logica“.

2. k. 148-276. „Philosophia naturalis a. 1702 “.

3. k. 277-383. "Philosophia ultranaturalis a. D. 1702 die 18 novembr."

4. k. 383-434. "Tractatus de anima“.

Podpisy: P. Ant. Gumowski Soc. Jesu, Laur. Heydenreich.

Brak początkowych kart.

\section{$\mathrm{Nr} 185$}

67. Pol. 2 potowa XVII w. $13,5 \times 8,5 \mathrm{~cm} . K$. 53. Opr. sk. wspt.

1. k. 1-51. „Rozmyślania pisane przez Kaspra D rużb i ckiego S. J." 152 Dopisek:" "Jest to charakter własny błog. Kaspra Drużbickiego".

150 Wzmiankuje o nim $\mathrm{Z}$ a łę ski, jw. T. 3 s. 833, 893.

151 Ur. $w$ r. 1695, prosił o wysłanie go na misje do Indii; Za $\mathrm{Z}$ es $\mathrm{ki}$, jw. T. 3 s. 893 , t. 4 s. 473 . W r. 1733 wspomniany jest jako prowincjal polski; $\mathrm{Ks}$.

S. Bednarski: Upadek i odrodzenie szkól jezuickich w Polsce. Kraków 1933 s. 46 uw. 3 .

${ }_{152}$ Ur. 6 I 1587, mmarł 2 IV 1662; por. S. Bed narski: Drużbicki Kasper. W: Pol. stown. biogr. V s. 403-404; Es tr. XV 332-342. 
2. k. 52-53. Pismo innej ręki: Życiorys Kaspra Drużbickiego.

Podpis: Teofila.

Nr 186

136. Pol. 1 pol. XVII w. $21,5 \times 16,5 \mathrm{~cm} . K .135$. Opr. tekt. XVIII w.

"Wizerunek d'ziwnej cierpliwości, tj. historia życia ... P. Zofiey z Tylic Tomickiej $\mathrm{W}$ lat trzy po śmierci przez spowiednika jej W. X. Staninisława B rzechfę ${ }^{153}$ Soc. Jesu spisana a teraz przez jednego tegoz zakonu Soc. Jesu w porządek należyty rozłożona". Streszczenia na marginesach.

Napisy: „Ex libris Fr. Borgia Doliński Soc. Jesu“. "Archivum domus Niedziałkowski".

Nr 187

287. Pol. 1753 r. $15,5 \times 10,5 \mathrm{~cm}$. S. 352. Opr. sk. wspt.

„Uwagi chrześcijańskie albo rozmyślania z przysiowia św. Ignacego pisane w nowicjacie Soc. Jesu“".

$\operatorname{Nr} 188$

1640. Łac. Poczatek XVIII w. $16 \times 10.5 \mathrm{~cm}$. S. 230. Opr. sk. uspł.

1. s. 1-230. „Brevis ac historica relatio de ritibus aliquot Sinicis facta a Casparo $\mathrm{K}$ a s t n e r S. J. missionario Sinensi et causae huius procuratore".

2. Druk: ,Acta causae rituum seu ceremoniarum Sinensium complectentia, Venetiis $1709^{\prime \prime}$. S. $1-71$.

3. is. $73-110$. „Decretum Congregationis Inquisitionis die 25 septembr. $1710^{\prime \prime}$.

Proweniencja: „Ex archivo provinciae Polonae Soc. Jesu“.

$\operatorname{Nr} 189$

1622. Eac. 1745 r. $19,5 \times 16 \mathrm{~cm} . K .130$. Opr. telit. późniejsza.

„Festia B. Virginis Mariae suis ritibus et celebritatibus devoluia ad nostra tempora ad concionatorios sacris oratoribus usus historico more conscriptía a P. Francisco H a mpel S. J. a. D. 174.5".

Liczne dopiski na wklejonych kartkach.

Proweniencja: „Ex libris Ignatii Fixiński C[ongregatio] O[ratorii] S[tudziannae]”.

$\mathrm{Nr} 190$

366. Eac. 1636 r. $18 \times 15 \mathrm{~cm}$. K. 268. Opr. perg. z XV w. z nutami $i$ tekstem Psalmu 94, wspt.

Skrypty szkolne.

1. k. 1-93. "In M. T. Ciceronis Rhetoricorum ad Gneium Herennium libros IV commentarius, a. $1636^{\prime \prime}$.

2. k. 94-138. "Institutionum dialecticarum syntagma, a. 1636“.

3. k. 140-268. "Theoria Aristotelicae Rhetoricae a. 1636 scripta sub P. [Andrea] $\mathrm{R}$ o s e $\mathrm{n}$ w a $1 \mathrm{~d}^{15 t}$ professore rhetoricae S. J.".

Podpis: Feliciani a Smogorzew Wąsowicz mpp.

Proweniencja: Bibliotheca Radomiensis Scholarum Piarum accepit 1756.

153 Zył w 1. $1588-27$ II 1645; Estr. XIII 387; Brown, jw. s. 136.

154 Zył $w$ 1. 1601-1667, doktor teol.; Załęski, jw, T. 2 s. 642; Estr. XVIII 611 


\section{Nr 191}

1539. Eac. 1726 r. $15 \times 10 \mathrm{~cm}$. K. 100. Opr. tekt. wspt.

1. k. 1-42. „Constitutiones clericorum regularium pauperum Matris Dei Scholarum Piarum". 8 rozdziałów.

2. k. 44-46. „Parabolae Salomonis seu sententiae ad varia“.

3. k. 48-85. "Ethicae poeseos disticha ad informandos puerorum mores accomodata auctore P. Gilberto Jo n in o S. J." 1 \%5

4. k. 89-100. „Monita tempore novitiatus ac reliquis vitae religiosae annis servanda".

Proweniencja: Ex libris P. Casimiri Zembrzuski S[cholarum] P[iarum].

\section{$\mathrm{Nr} 192$}

1772. Eac. XVIII w. $13 \times 8 \mathrm{~cm}$. S. 477. Opr. tekt. wspl.

1. s. $1-44$. „Mathiae Casimiri $\mathrm{S}$ a r b i e vi i S. J. ${ }^{156}$ Epigrammatum liber unus".

2. s. 45-117. "Quaestiones et responsa eruditorum".

3. s. 121-477. Słownik imion własnych od B do $\mathrm{S}$.

Podpis: P. Theophili a S. Francisco Sch. Piarum.

Proweniencja: Biblioth. Radom. S.P.

V. KONGREGACJA BARTEOMIEJA HOLZHAUSERA W WẸROWIE

(tzw. Komuniści)

Nr 193

1523. Eac., pol. $1768-1795$ r. $16,5 \times 10 \mathrm{~cm}$. S. 142. Opr. tekt. wspt.

1. s. 1-93. "Clericus ordinandus, scriptus per Joannem Koch enski C[lericorum] S[aecularium] in Seminario Vengrovicensi a. '1768“.

2. s. 94-104. "Institutio christiana".

3. s. 105-115. Prognostyki, r. 1795.

4. s. 116-142. Proroctwo błogosł. Bartłomieja Holzhausera.

\section{MISJONARZE SW. WINCENTEGO}

\section{a) KRAKOW}

$\mathrm{Nr} 194$

1558. Pol., tac. 1771 r. $16,5 \times 10 \mathrm{~cm}$. S. 255. Opr. tekt. wspt.

Kazania i katechizm w pytaniach. „Zbiór nauk chrześcijańskich zebranych $\mathrm{w}$ domu krakowskim na Stradomiu 6 paźdz. 1771“.

Podpis: X. J. Barciňski psalterzysta sandomierski.

b) ŁOWICZ

$\mathrm{Nr} 195$

684. Eac. $1736-1738$ r. $19,5 \times 16 \mathrm{~cm}$. K. 170. Opr. tekt. wspt.

Skrypty szkolne.

155 Zmarł 9 III 1638; Estr. XVIII 611.

156 Zył w 1. 1556-1640; Enc. Now. XXIV 385-387; Estr. XXII 124-135; B rown, jw. s. 359-363. "Epigrammatum liber I" byl drukowany w' Divione przez P. Polliot w 1645 r. 
1. k. 1-34. „Logica".

2. k. 35-98. „Scientia naturalis sive disputationes in libros Aristotelis de auscultatione physica, die 2 maii 1736 ".

3. k. 98-106. „Metaphysica, finita: 18 maii“.

4. k. 106-130. „In libros Aristotelis De ortu et interitu, finitum 18 septembris".

5. k. 130-164. „De anima“.

6. k. 164-170. "De metheoris".

„Haec philosophia dictata est a P. Antonio R o g a l a, scripta a me Mathia Josepho Kuczewski philosopho absolutio d. 18 iunii 1738. Ego Mathias Kuczewski clericus Congregationis: Oratorii S. Philippi Nerii ex Studzianna ad Seminarium sumptu proprio missus fui. Theologia moralis in Seminario Elowicensi explicata per professores Barcz et Bryl ${ }^{*}$ ski, Patres Congregationis Missionis. Superior Congr. Miss. est Andreas Rink, procurator R.D. Falaśkiewicz". Lista wykładowców i słucharczy.

$\mathrm{Nr} 196$

1566. $ヒ a c .1778$ r. $19 \times 11,5 \mathrm{~cm}$. S. 252 . Opr. sk. wspt.

„Rubrum seu scientia de quibusdam ad recitationem Divini Officii necessariis in Seminaro Łowicensi per Adm. Rev. D. G. K." Nuty gregoriańskie.

Podpis: X. Swięckiego Anioła.

c) PRZEMYSL

$\mathrm{Nr} 197$

95. Eac., pol. $1713-1714$ r. $15,5 \times 10 \mathrm{~cm}$. S. 232, 343. Opr. bez okt. wspt.

Przykłady kaznodziejskie i uwagi ascetyczne.

1. s. 1-195. „Supplementum horrei spiritualis partis I pro missionibus, Premisliae a. D. 1713 in septembre collectu's".

2. s. 198-232. "Varia exempla de SS. Eucharistiae Sacramento".

3. s. 1-343. "Praxis ascetica hominis missi a Deo, a. D. 1714 in iulio Premisliae elaborata".

Pïsmo wielu rąk.

Proweniencja: „Ex libris presbyterorum Congr. Ms, post obitum A.R.D. Kowalski“".

Brak końca.

\section{PAULINI (?)}

$\mathrm{Nr} 198$

644. Łac. 1663 r. $19 \times 15,5 \mathrm{~cm}$. K. 196. Opr. tekt. wspt.

Skrypty szkolne.

1. k. 1-116. „Ad IIam IIae D. Thomae Aq. de fide, spe, charitate, scriptum et finitum a. 1663 professore P. Mathia B leshenski, Fr. Wilhelmus Ord. S. Pauli Eremitae professus".

2. k. 118-196. „De poenitentia, finitum 26 iunii 1663 professore F. P. B resne no: [?], Fr. Wilhelmus S. Ord. S. Pauli Eremitae professus".

Proweniencja: kościół w Beszowej. 


\section{PIJARZY \\ a) GORA}

$\mathrm{Nr} 199$

679. Eac. 1696 r. $20 \times 16 \mathrm{~cm}$. S. 328. Opr. tekt. wspt. zniszczona. Skrypt szkolny.

"Philosophia universa Thomae Aquinatis doctrina firmata, in Wierzboviano collegio Scholarum Piarum tradi coepta die 17 sept. 1696, per me Danielem a S. Laurentio" [Rosecki] ${ }^{157}$.

Napis: Bibliotheca collegii Gorensis Scholarum Piarum.

Brak ostatnich kart.

b) . ŁOWICZ

$\mathrm{Nr} 200$

348. Łac., pol. 1735-1736 r. 21,5×17,5 cm. S. 242. Opr. tekt. wspt. Zasady wymowy.

„Eloquentia ad Potociorum Pilavae sidus in collegio Eowiciensi Scholarum Piarum porrecta anno 1735-1736“.

Podpis: X. A. Rogalski.

c) PIOTRKOW

$\mathrm{Nr} 201$

351. Łac., pol. 1738 r. $19,5 \times 16 \mathrm{~cm}$. K. 144. Opr. tekt. wspt.

Skrypt z retoryki: zasady, przykłady mów i wiersze.

„Liber rhetoricorum in duas partes divisus, quarum prima praecepta et regulas, altera praxes et exempla continet, in collegio Petricoviensi Schol. Piarum traditus a. 1738 die 12 octobris".

Napis: „Hic liber est proprius Josephi Pawlowicz auditoris scholae rhetorices a. $1739^{\prime \prime}$.
d) PODOLINIEC

Nr 202

13. Łac., franc. $1718-1730 r .16 \times 9,5 \mathrm{~cm}$. K. 26, 64. Opr. tekt. wspt.

Wypisy i uwagi ascetyczne.

1. k. 1-26. „Manuscrit tiré de plusieurs auteurs par le Pere J e an de la V is itation de la Sainte Vierge de l'Ordre des Ecoles Pieuses in domo Podolinensi a. $1730^{\text {". }}$. Podpis: Jo. Ozeroon ${ }^{158}$.

2. k. 1-64. „Itinerarium novelli neligiosi, collectum a Gelasio di Cilia, Francofurti a. 1718“.

Proweniencja: Biblioth. Radom. Schol. Piarum.

$\mathrm{Nr} 203$

1767. Łac., pol. 1742 r. 16,5×10,5 cm. S. 369. Opr. sk. wspt. Wypisy z geografii i historii. B. V. M.

1. s. 1 -84. „De statu Europae“ — zebral Joannes a Visitatione

157 Es tr. XXV 362-363.

158 A. Obertzon nazywał się $W$ zakonie Joannes a Visitatione B. M. V. Historia Domus Varsaviensis Scholarum Piarum. Oprac. L. Chm a j. Wrocław 1959 (Archiwum dziejów oświaty [t.] 1) s. 59 uw. 196. 
2. s. $84-98$. "Series et acta praecipua ducum et regum Poloniae“.

3. s. 99-221. "Series et res nonnullorum sanctorum, beatorum ac iustorum Regni Poloniae ex libro sub titulo Forteca duchowna auth. Petro Hyacintho Pruszcza ${ }^{\mathbf{1 5 9}}$ circa a. 1662".

4. s. 222-260. „Krótkie niektórych herbów polskich opisanie z Marcina Bielskiego kronikarza polskiego i syna jego Joachima Bielskiego ok'. r. $1597^{\prime \prime}$.

Razem oprawiony druk: "Historia naturalis Regni Poloniae opera P. Gabrielis Rzą c z y ńs k i loo S. J., impressa Sandomiriae typis $\mathrm{S}$. J. $1721^{\prime \prime}$.

Podpis: F. Joannes a Visitatione B.V.M. die 20 februarii 1742. A. Obercon.

Proweniencja: Bibliotheca Radomiae Schol. Piarum. A.K.mp.

e) RADOM

$\operatorname{Nr} 204$

400. Łac. XVIII w. $16,5 \times 10 \mathrm{~cm}$. K. 634. Opr. sk. wspt.

Materiały kaznodziejskie. "Varia notata per alphabetum ad conciones servientia patris $\mathrm{Cajet}$ ani a S. Pernardo". Hasła od A do V.

Nr 205

367. Eac., pol. 1700-1701 r. 18,5×15,5 cm. K. 57. Opr. tekt. wspt.

Wzory: mów kościelnych i świeckich. „Coeli rhetorici in collegio Wąsoviciano Radomiensi Schol. PP., aperti anno 1700 die 22 septembris, finitum 16 iulii 1701. Per me vero scripta A. I.“

Proweniencja: dar ks. Jana Wiśniewskiego r. 1912.

\section{$\mathrm{Nr} 206$}

403. Łac., pol. 1723 r. $15 \times 10 \mathrm{~cm}$. K. 218. Opr. perg. wspt. Na pergaminie tekst zatarty $z$ inicjatami.

„Orator extemporaneus-politicus-historicus-ecclesiasticus-scholasticuspublicus P. Cajetani a S. Bernardo Schol. P. Rad.“

\section{f) RZESZOW}

$\mathrm{Nr} 207$

680. Eac. $1736-1737$ r. $20 \times 15 \mathrm{~cm} . K .247 \mathrm{~cm}$. Opr. tekt. wspt. zniszczona.

Skrypt szkolny. „Philosophia Thomistica secundum divisionem in logicam, physicam, metaphysicam, ethicam comprehensa; tomus I De logica in Ressoviensi Scholarum Piarum collegio proposita a. 1736 die 20 octobris, finitum 23 iulii $1737^{\prime \prime}$.

\section{$\mathrm{Nr} 208$}

1706. Eac. $1742-17 \dot{4} 3$ r. $19,5 \times 15 \mathrm{~cm}$. K. 68. Opr. tekst. wspt.

Podręcznik poetyki. „Nucleus poeticus artis poeseos praecepta complectens, propositus in Lubomirsciano Ressoviensi S.P. collegio $1742-1743$ die 10 octobris".

158 Estr. XXV 330.

160 Estr. XXVI 541. 
g) WARSZAWA

$\mathrm{Nr} 209$

674. Łac. 1731-1732 r. 19,5×16 cm. S. 364. Opr. bez okt. wspł. Skrypt szkolny. „Philosophia iuxta mentem Thomae Aq. in Regio collegio Scholarum Piarum a. 1731--1732 die 10 sept." Napis zatarty.

1. s. 1-128. "Logica“.

2. S. $129-302$. "Physica“".

3. s. 303-364. "Metaphysica".

Podpis: Alexander Krapocki auditor philosophiae.

Brak końca.

Rękopis zniszczony.

$\mathrm{Nr} 210$

743. Pol. XVIII-XIX w. $23 \times 18 \mathrm{~cm}$. S. 176. Opr. tekt. wspt.

„Logika zebrana przez X. Józefa Hermana O sińskie g o ${ }^{161}$ prof. filozofii w konwikcie wielkim pijarskim w Warszawie“. Dodano logarytmy i trygonometrię. Spis rzeczy. Pisał Wincenty Trębicki.

\section{$\mathrm{Nr} 211$}

1528. Łac. 1770 r. $17 \times 10,5 \mathrm{~cm}$. K. 62. Opr. tekt. wspt. zniszczona. „R e m ig i u s a S. Erásmo ${ }^{162}$ Schol. Piarum: Summarium iudicii regularis actum per P. L a u re ntium a S. Rosalia [Wawrzyniec Klisiewicz] ${ }^{163}$ prof. collegii Varsaviensis".

$\mathrm{Nr} 212$

1551. Łac. 1747 r. $15,5 \times 10 \mathrm{~cm}$. K. 78 . Opr. tekt. wspt.

,Scriptae a Francis co Xaverio a S. Joanne Nepomuceno regulae novitiorum - - Scholarum Piarum ad proprium usum".

IX. REFOR M A C I

a) $\mathrm{BIECZ}$

$\mathrm{Nr} 213$

1538. Łac. 1738 r. $15 \times 10 \mathrm{~cm}$. K. 212. Opr. sk. wspl.

Skrypty szkolne.

1. k. 1-12. "Regulae ex V et VI Decretalium".

2. k. 14-98. "Summa ss. canonum".

3. k. 99-212. "Tractatus de variis fidei catholicae articulis in conventu Becensi ad s. Annam".

b) KAZIMIERZ

Nr 214

606. Łac. $1792 r .17,5 \times 11,5 \mathrm{~cm}$. K. 50. Opr. sk. wspl.

Skrót wiadomości dla spowiedników. „Examen tripartitum: 1. k. 1-16 De sacramento poenitentiae, 2. k. 16-40 De ministro sacramenti poeni-

101 Zył w 1. 1738-1802; Enc. Now. XVII 524; Estr. XXIII 465.

162 Es t r. XXVI 242.

163 Historia Domus Varsaviensis Scholarum Piarum s. 37 uw. 112. 
tentiae, 3. k. $40-50$ De restitutione ad usum Patris Simonis Reformati, 1792 conscriptum Casimiriae".

Napis: Ad usum P. Antonii Tomaszewski Reformati a. D. 1792.

c) KRAKOW

$\mathrm{Nr} 215$

602. Eac. 2 pot. XVIII w. $17 \times 11 \mathrm{~cm}$. S. 103. Opr. tekt. wspt.

Skrót teologii moralnej. „Apparatus universae theologiae moralis pro examine ad audiendas confessiones a quodam confessario consriptus et mihi F. Petro Baptistae, Provinciae Reformatae Minoris Poloniae professo simplici, usui accomodatus diebus iunii 1785“.

\section{N.r. 216}

279. Eac., pol. XVII-XVIII w. $9 \times 7,5 \mathrm{~cm}$. K. 174. Opr. sk. wspt.

Podręcznik rekolekcyjny. "Recollectio octidua iuxta methodum P. Daniel Bry kn e r" 164 .

Proweniencja: Bibliotheca conventus Radomiensis PP. Bernardinorum.

$$
\operatorname{Nr} 217
$$

244. Łac. 1792 r. $19,5 \times 11,5 \mathrm{~cm}$. K. 64. Opr. tekt. wspt.

Podręcznik szkolny. „Rhetorica ecclesiastica et civilis per Stephanum $\mathrm{D}$ e $\mathrm{m}$ e d e $\mathrm{n}^{165}$ rhetorices lectorem iuventuti seraphici ordinis a. D. 1792 extradita".

$$
\text { d) LUBLIN }
$$

$$
\operatorname{Nr} 218
$$

558. Eac. $1726 r .19,5 \times 15,5 \mathrm{~cm} . K .174$. Opr. tekt. wspt.

Skrypt wykłaidowcy. „Altum Pelagus - - a Joanne Duns Scoto - scrutatum —— ad aedes s. Casimiri Lublini propositum a. 1726. Liber I Sententiarum".

$$
\begin{aligned}
& \text { e) OSIECZYN } \\
& \mathrm{Nr} 219
\end{aligned}
$$

16. Eac., pol. 1696 r. $15 \times 8,5 \mathrm{~cm}$. K. 178. Opr. tekt. wspt.

Nauka reguły zakonnej, rozmyślania i modlitwy.

1. k. 1-83. "Compendium eorum, quae fratres nostri per annum probationis suae scire debent".

2. k. 86-178. „Manuale seraphicae pietatis in ordine strictioris observantiae reformatorum in conventu Osiecuensi porrectum a. D. 1696 die 13 martii per me fr. Silvestrum W iśniow s c i u clericum".

Podpis: Valentinus Tirczyński senior ecclesiae Premysliensis.

f) PINCZOW

$\mathrm{Nr} 220$

681. Łac. 1731 r. $20 \times 15,5 \mathrm{~cm}$. S. 172, 281, 83. Opr. sk. wspt. Skrypt szkolny.

1. s. 1-172. "Introductio ad logicam seu dialectica".

164 Enc. Now. II 624; Estr. XIII 384.

165 Pisał się: de Męem, pracował w Krakowie i tam zmarł 5 VII $1843 \mathrm{r}$. Informacja $z$ Archiwum Prowincji OO. Reformatów $w$ Krakowie. 
2. s. 1-281. „Philosophia naturalis, vulgo physica ad mentem Subtilis Doctoris Duns Scoti“.

3. s. 1-83. „In philosophiam transnaturalem, vulgo metaphysicam prologus. Auditorium Pinczowiense F. O. M. a. 1731“.

$\mathrm{Nr} 221$

382. Eac., pol. 1751 r. $16,5 \times 10,5 \mathrm{~cm}$. S. 47. Opr. tekt. wspt.

„Modus qui observari debet in missionibus a fratribus Minoribus Reformatis Prov. Minoris Poloniae a. D. 1751. Conventus Pinczoviensis Patrum Reformatorum".

Napis: sposób odprawowania misji OO. i XX. Misjonarzy Congr. S. Vincentii à Paulo.

g) POZNAÑ

$\mathrm{Nr} 222$

653. $1739-1741$ r. $20 \times 18,5 \mathrm{~cm}$. K. 540. Opr. tekst. wspl.

Skrypty szkolne.

1. k. 1-84. „Liber IV Sententiarum seu tractatus speculativo-moralis de sacramentis iuxta mentem Joannis Duns Scoti PP. Reformatis in conventu Posnaniensi ad s. Casimirum per $\mathrm{P}$. Atanasium $\mathrm{D}$ u $\mathrm{n}$ in traditus a. D. 1741. Scripsit Jacobus Wierski“.

2. k. 85-172. „Sacramenta ad mentem Doctoris Subtilis exposita in conventu Posnaniensi PP. Reformatorum ad s. Casimirum elucidata a. 1740 die 2 sept. A. A."

3. k. 177-330, ,Liber I Sententiarum de Deo uno, a. D. 1741 die 1 sept. inchoatus, per P. A ng elum s. theologiae lectorem editus".

4. k. 333-377. „Tractatus de gratia divina studio Patrum Reformatorum in conventu Posnaniensi traditus a. D. 1741 a P. R e migio s. theologiae lectore et $\mathrm{P}$. Jacobro Wierski C[ongr.] O[rator.] S[ancti] P[atris] Nerii presbytero".

5. k. 378-421. „Tractatus de peccatis studio Posnaniensi PP. Reformatorum a. D. 1740 die 10 sept. inchoatus".

6. k. 424-482. „De incarnatione Verbi in conventu PP. Reformatorum Posnaniensi 1739 die 4 novembr."

7. k. 485-506. „De fine hominis“.

8. k. 527-540. "Tractatus de actibus humanis studio: conventus P.osnaniensis PP. Reformatorum traditus, a. D. 1740 die 15 martii sub P. Remigio d. theologiae lectore promulgatus".

\section{h) SANDOMIERZ}

$\mathrm{Nr} 223$

592. Łac. 1744 r. $15 \times 10 \mathrm{dm}$. K. 89. Opr. sk. wspt.

"Compendium controversiarum de praecipuis articulis fidei catholicae contra moderni saeculi sectarios, conscriptum a P. Mariano $E$ a pćz y ński ${ }^{166}$ patre Provinciae a. D. $1744^{\prime \prime}$.

$\mathrm{Nr} 224$

133. Łac. 1736 r. $18,5 \times 14 \mathrm{~cm}$. S. 503, 80. Opr. sk. wspt.

16 Kaznodzieja w Sandomierzu. 
Uwagi i pouczenia ascetyczne dla nowicjuszy.

1. s. 1-503. „Schiola coelestis et divina, id est theologiae asceticae et mysticae - explanatio a. D. $1736^{\prime \prime}$.

2. s. 1-80. "Soliloquila seu lectiones proponendae a magistro novitiorum".

Napis: „Hoc opus ad instructionem novitiorum compilatus opera P. Ildefonsi żelaśkiewicz, Provinciae Minoris Poloniae custodis, in conventu Sandomiriensi Ordinis Min. Reformatorum magistri elaboratum a. D. 1736“. Inny napis: „Labor triennalis in magisterialu novitiorum in conventu Sandomiriensi Fr. Min. Ref. P. Ildef. Żelaśkiewicz - - “.

$\mathrm{Nr} 225$

468. Pol. 1 poł. XIX w. 21,5X17 cm. 126 poszytów i luźnych kart.

Ks. Konrad P i r a m ow i c ${ }^{167}$ reformat: Kazania świąteczne, pasyjne, niedzielne, na uroczystości N. M. P. i świętych oraz przemówienia żałobne i okolicznościowe.

i) SOLEC

$\operatorname{Nr} 226$

70. Łac., pol. 1706 r. $15,5 \times 9,5 \mathrm{~cm}$. K. 204. Opr. sk. wspl.

Rozmyślania i modilitwy reformata $z$ Solca.

Napis: „Ingressus sum religionem 1676, natus sum a. 1652 die 26 aprilis, annos physicos in Solec 30, annus praesens $1706^{\prime \prime}$.

j) WARSZAWA

$\mathrm{Nr} 227$

515. Eac. $1664-1665$ r. $32 \times 21 \mathrm{~cm}$. K. 353. Opr. tekt. wspt.

Skrypty szkolne. "Summa theologiae ad mentem Doctoris Subtilis“. K. 1-91 "De Deo uno", k. 92-138 "De Deo trino", k. 139-165 „De incarnatione", k. 167-213 "De angelis", k. 214-223 „De homine", k. 224-24: "De fine hominis", k. 246-327 „De actibus humanis", k. 328-336 „De legibus", k. 337-353 „De gratia".

$\mathrm{Na}$ końcu wszytio druk: „Conclusiones theologicae quae defenduntur publice Varsoviae assistente P. Bernardo. Gutowski ${ }^{168}$ Ord. Min. Reform. s. theol. lectore, a. 1665 die 1 ianuarii“.

Proweniencja: Bibliotheca collegii Radomiensis.

\section{N D E K S \\ NAZW OSOBOWYCH WYSTĘPUACYCH W OPISACH \\ (Cyfry oznaczaja numery pozycji)}

Albericus zob. Alberyk

Albert Wielki św. 4, 165

Albert z Easku 2, 4, 5

Alberyk, jezuitia 162

Alexandrowicz Andrizej 28
Andreae Joannes zob. Joannes Andreae

Andrzejowicz Józef 147

Angelus zob. Aniol

Aniol, reformat $222(3)$

Anzelm św. 64 (6)

167 Kaznodzieja katedralny w Sandomierzu; Pelczar, jw. Cz. 2 s. 381--382: Enc. Now. XIX 402; Estr. III 387.

108 Zmarł ok. 1696 r. Estr. XVII 477. 
Arystoteles $1(1,5), 2,4,5,6,8(1-6,9)$ $9(2,3), 76,84,89,108,109,116,160$ $175,181,190,195$

Axonius Albert 30

Barciński J. 194

Barcz, misjonarz 195

Bargiel Pawel 26

Bartlomiej Holzhauser bł. 193

Bembus Mateusz 126, 127

Benesius 64 (5)

Bentkowski Feliks 50

Berszowski Krzysztof 2

Bethman Jakub 147

Bidziński Hilary 89

Biegalski Maciej 83, 84

Bielski Joachim 203

Bielski Marcin 203

Biernacki Józef 108

Blesheński Mathias zob. Bleszeński Maciej

Bleszeński Maciej 198

Bobiński Franciszek 34

Bolmiński Sebastian 69

Borowski Ignacy 118

Bosman Sebastian 76

Bresnenius F. P. 198

Brolnicki Andrzej 55

Bron... Teofil 12

Brückner Aleksander 65

Brykner Daniel 216

Brylski, misjonarz 195

Brzechfa Stanisław zob. Brzechwa Stanisław

Brzechwa Stanislaw 186

Brzeski Ksawery 149,150

Budziński Andrzej 173

Budziński Jan 22

Cacabus zob. Catabus

Caesarius Franciscus zob. Cezary Franciszek

Caesarius Joannes zoib. Cezary Jan

Cajetanus a S. Bernardo zob. Kajetan od św. Bernarda

Carpentarius Jacobus 1 (10)

Catabus 64 (5)

Cezary Franciszek 116

Cezary Jan 14

Chiarini Ludwik Alojzy 48

Cycero 1 (9), 174,190

Cinerski Jan 8 (11)

Clemens de Radymno zob. Klemens $z$ Radymna

Corzys Stanislaus de zob. Korzybita Stanisław

Cricius Andreas zob. Krzycki Andrzej

Czaplic Stanisław $24(2,4,6)$

Czerwiński Gabriel 56

Dambrowski Alberlus zob. Dąbrowski Albert
Daniel a S. Laurentio zob. Rosecki

Daniel

Dantyszek Jan 3J (7)

Dargohn (?) 53

Dąbrowski, jezuita 129

Dąbrowski Albert 8 (5)

Dąbrowski Jan Andrzej 67

Dąbrowski Jan Chryzostom 41, 45, 48, 49,51

Dembińska P. C. A. 141

Demeden Stefan 217

Dlugoleczky Andreas zob. Dlugolecki Andrzej

Dlugolecki Andrzej 1 (2)

Dlugosz Wojciech 121

Dobel Stanisław 129

Doctor Subtilis zob. Duns Szkot

Doliński Franciszek Borgiasz 186

Dominicus F. zob. Dominik F.

Dominik F. 104

Doszowski 133

Draski Adam 5, $18(2,3,6)$

Drews Jan 162, 165

Drużbicki Kasper 185

Dunin Atanazy 222

Duns Szkot $8(10), 76,77,78,82,83,85$, $86,88,90,94,108,218,220,222(1,2)$

Duńczewski Stanisław 14 (9)

Dymszewicz Abraham 169

Dzianott Antoni 82

Dziewanowski Marcin 183

Engelbrecht Marcin 56

Etting Ludwik 108

Ewaśniewicz Maciej 1

Falaśkiewicz, misjonarz 195

Filipowski Grzegorz 13

Fixiński Ignacy 189

Fragstein Franciszek 178

Franciscus zob. Franciszek

Franciscus Xaverius a S. Joanne Nepomuceno zob. Franciszek Ksawery od św. Jana Nepomucena

Franciszek, jezuita 111

Franciszek Ksawery od św. Jana Nepomucena 212

Fredericus zob. Fryderyk

Fryderyk 62 (2)

Gawarecki Wincenty Hipolit 61

Gawęcki P. 128

Gelasius di Cilia 202

Gembicki Andrzej 30 (7)

Geminiano Joannes a zob. Joannes a Geminiano

Giuźwicz (?) Stanisław 139

Glac Józef 71

Głażewicz, jezuita 182

Glowacki Ignacy 146,147

Gołuchowski Wojciech Józef 35, 53

Gorscius Jacobus zob. Górski Jakub 
Gostyński Kazimierz 59

Górski Jakub (1525-1585) $1(1,8) 3,5$

Górski. Jakub (1585-1652) 25

Górski Karol 40

Gregorowicz Zygmunt 1 (8), 4, 8 (7)

Grusecki Albert 132

Grygorowicz Zygmunt zob. Gregorowicz Zygmunt

Grymosz Marcin 180

Grzegorz Wielki, papież św. 73

Guarient Felicjan 158

Gumowski Antoni 184

Gutowski Bernard 227

Hampel Franciszek 189

Haraczkiewicz Stanisław 154

Harrasch, jezuita 134

Havior Jan Baptysta 157

Hercius Pawel 20 (7)

Heydenreich Laur. 184

Hieronim z Pragi 64 (1)

Holzhauser Bartłomiej bł. zob.

Bartłomiej Holzhauser bł.

Horbaczewski Antoni 76

Hostyński Jan 137

Hypisch Franciszek 176, 177

Ignacy Loyola św. 187

Jachimowski Tadeusz Julian 35

Jacobus de Srzem zob. Jakub ze Sremu

Jacobus Ustiensis zob. Jakub z Ujścia

Jakub z Ujśsia 7,17

Jakub ze Ŝnemu 92

Jakubowski A. 50

Jakubowski Michał 154

Jan, prezbiter $\mathrm{w}$ Radomiu 65

Janczyński Pawel 116

Janicki Albert 2, 4, 5, 18, 20 (4-8)

Jankowslki Józef Emanuel 15

Januszewski A. 44

Jaross Jerzy 157

Jasiński. Mar in $55,72,120,138,139$, $146,147,153,155$

Jaśkiewicz Jan 33

Jaźwiński Marcin 115

Joach im, bernardvn 83:

Joachim, pijar 175

Joachimus zob. Joachim

Joannes Andreae 62 (1)

Joannes a Geminiano 107

Joannes de Sacrobusto zob. Sacro Busto Joannes de

Joannes Protiva zob. Protiva Jan

Joannes, presb. in Radom zob. Jan, prezbiter $\mathrm{w}$ Radomiu

Joannes de Szczekna zob. Štěkna Jan

Joannes a Visitatione B. M. V. zob. Obertzon Jan

Jonini Gilbert 191

Joninus Gilbert zob. Jonini Gilbert
Jurkowski Stanisław 8 (11), 18 (1)

Juśkiewicz Mikołaj 142

Kajetan od św. Bernarda 204, 206

Kamieński 113

Kantor kościoła przemyskiego (2 pol. $\mathrm{XV}$ w.) 66

Karyński Wawrzyniec $20(4-6), 24$ (1)

Kastner Kasper 188

Kirstein Michał 166, 167, 168

Klemens z Radymna 81

Klisiewicz Wawrzyniec 211

Kobielski Józef 114

Kocheński Jan 193

Kokoszyński 144

Kołozwarski, jezuita 122

Kopf Ferdynand 23

Kordanowski (?), karmelita bosy 68

Korzyb Stanisław 73, przyp. 108

Kostanecki Pawel 181

Kostkiewicz Andrzej Gabriel 54

Kowalski, misjonarz (?) 197

Kozlowski Stanisław 52

Krapocki Aleksander 209

Kraśnicki Mateusz 4, 8 (2)

Kriliński Prosper 7

Krzewska, benedyktynka 143

Krzycki Andrzej 74

Kubicki Pawel 36

Kucępa Maurus zob. Kuczępa Maur

Kucharski Andrzej 6, $18(7,8)$

Kuczewski Maciej Józef 134, 135, 195

Kuczęoa Maur 23, 39

Kulbiński Bartłomiej 77, 78

Kulczycki Franciszek 108

Kurowski J. 15

Kuszewski 53

Lascensis Alburtus zob. Albert z Easku

Laurentius a S. Rosalia zob. Klisiewicz Wawrzyniec

Legucki Bonawentura 10

Legucki Michał 10

Linacer Tomasz 5

Linacrus Thomas zob. Linacer Tomasz

Lipnicius Andreas zob. Lipnicki Andrzej

Lipnicki. Andrzej 8 (11)

Lisowski. Hieronim 90

Lowensztein Teodor 129, przyp. 127a

Lukini Jan 21

Kapczyński Marian 223

Laski Karol 117 (1)

Eosiewski (Eosiewicz) Krzysztof 166, 1.71

Eosiewski Stanisław 167, 168, 169, 170

Eucki, jezuita 114

Łyszczyński Jan Kazimierz 162

Malinowska Maria 57

Małachowski Cyprian 122

Małyński Aleksander 93 
Manfré Jan 117 (2)

Maciej z Radomska 58, przyp. 91

Marceli, bernardyn 84

Marcellianus zob. Marceli

Marcin, brat 64

Marcin, piszący skrypt 127

Marski O. $1 \mathrm{CO}^{\circ}(2)$

Martinus zob. Marcin

Massuvius Thomas 129, 130

Matthias de Radomsko zob. Maciej

$z$ Radomska

Mazurkowic Maciej 5

Micanus (Mikanus) Stefan 1 (2)

Michael zob. Michal

Michael de Radomsko (?) zob. Michał z Radomska

Michał, lekstor 104

Michal z Radomska 58

Mikolaj od św. Antoniego 21

Mikolaj, syn Wiganda 66, przyp. 103

Mikowski Kanty 21

Mikułowski Adam 118

Misiórski Antonj. 42, 99

Młodzianowski Tomasz 128

Moszyńska Marianna 141

Muchowski Maciej 136

Muris Joannes de 9

Nantius Albertus 12

Narboth Bazyli 141

Narewicz Andrzej 170, przyp. 144a

Narmunth Milkołaj 162, 161

Naymanowicz Jakub $24(7,8)$

Nayrzałkiewicz Bartłomiej 136

Nazarewicz Marcin 118

Nicolaus a S. Antonio zob. Mikołaj od 'św. Antoniego

Niedziałkowski 186

Niezabitowskí A.lojzy 101

Obertzon (Obercon) Jan 2c2, 203

Ochocki Mikołaj 8 (8)

Okoński Woiciech 39

Olszewski. Jakub 174

Olszyński Bazyli 9 (3)

Opatovius Adamus zob. Opatowsk1 Adam

Opatowskj. Adam 16

Orłowski Michał 121

Orzeszkowski Wincenty 47

Osiński. Józefl Herman 210

Paczyntzky Jan 175

Papencovius Albertus zob. Papenkowic Albert

Papenkowic Albert 2, 5

Paschalis a S. Rosa zob. Paschalis od św. Róży

Paschalis od św. Róży 104

Paszkiewicz, jezuita 133

Pawel z Zatora 65

Pawłowicz Józef 201
Peński Walenty 120

Perkiewicz Pawel 138

Perłówna Karolina 114

Petrarka Franciszek 73

Petrus Baptista 215

Pęczkowicz Maciej Stanisław 69, 70

Pęgowski Franciszek 74

Piotrowicz Ludwik 43, 81

Piotrowski Eukasz 2, 7, 8 (10)

Piramowicz Konrad 225

Pleszczyński Sebastian 1

Plucharz Seweryn 109

Plucieńskj. Franciszek 155

Pociszowski Michał 82

Podlesiecki Aleksander 111

Politowicz Dionizy 20 (8)

Polaniecki Jan Kapistran 77, 78

Porfiriusz 1 (4)

Praski Stanislaw 60

Prociva Joannes zob. Protiva Jan

Protiva Jan 64 (5)

Protaszewicz Gordian 173

Pruszcz Jacek 203

Przanowski Maciej 121

Przyborowski Walery 60, 75

Frzygodzki Wiktor 134

Przyłuska Angela 91

Przyluski Stanisław $30 \quad(1,2)$

Purchotius Edmundus 117

Radecki Romuald 141

Radomowski Mikołaj 173

Radzimiński Marcin 8 (4)

Redel Augustyn Kazimierz 56

Redelius Augustinus Casimirus zob.

Redel Augustyn Kazimierz

Remigius zob. Remigiusz.

Remigius a S. Erasmo zob. Remigiusz od św. Erazma

Remigiusz, reformat 222

Remigiusz od św. Erazma 211

Reszka Stanisław 111

Resztak Stanisław 29

Rethia Stanislaus zob. Reszka

Stanisław

Rhenniok Michał 179

Rink Andrzej 195

Robak 107

Robiecki Jan Ewangelista 97

Rochmannius Andreas 172

Rodericus Zamorensis 73

Rogala Antoni 195

Rogalski A., pijar 200

Rojek vel Rojkowski Naurycy 100 (3)

Rokoszny Józef 37, 65

Rosecki Dapiél 199

Rosenwald Jedrzej 190

Rösner Łukasz 176

Rozczewic Adam 24 (11-14)

Różycki Jan 24 (10)

Rudolski Marcin $13 \varepsilon$

Rudzki Jan 27, 28 
Rzączyński Gabriel 203

Sacro Bosco zob. Sacro Busto Joannes de

Sacro Busto Joannes de 9 (5)

Sadowski Stanisław Kazimierz 9 (1-4)

Salvanus de Bolonia (?) 62 (2)

Sampławski Antoni 114

Sarbiewski Maciej Kazimierz 192

Schedel Krzysztof 7

Schedelius Christophorus zob.

Schedel Krzysztof

Scheffler Tomasz 56

Schober Severinus zob. Szober

Seweryn

Schwartzemberg-Czerny Franciszek zab. Szwarcemberg-Czerny Franciszek

Szczebietowicz Pawel $30(1,2)$

Szczekna Jan zob. Štěkna Jan

Senniey Władysław 158

Sergiewicz Sebastian 5

Severinus zob. Seweryn

Seweryn, jezuita 109

Simon zob. Szymon

Skolimowski Rafal 45

Skrzyński Albert 3

Slupc... Antoni 127

Słomczyński Antoni 100 (5)

Slupecki Marcin 130

Słykowski Justus 100 (1)

Sokalski Tomasz 47

Solikowski Mikolaj 4, $8(9,11)$

Solsiński Tymoteusz 100 (1)

Społezyńskj Maciej 29

Stanislaus zob. Stanis?aw

Stanislaus de Corzys zob. Korzyb

Stanisław

Stanislaw, bernardyn 91

Stanisławski Jerzy 159

Stańkowski Jan Baptysta $117(1,3)$

Starzechowski Jan 12

Stefanowski Hieronim 172

Stěkna Jan 664 (5)

Straszyński Wacław Kazimierz 19

Struwe Henryk 46

Sulikowski Mikołaj zob. Solikowski Mikołaj

Szaniawski Józef Kalasanty 103 (2)

Szarkiewicz Jakub 51

Szarwey Szymon 96

Szczuka Kazimierz $68(6,7)$

Szeligowski Jan 27

Szeligowski Stanisław 27, 28

Szober Seweryn 85, 86, 175

Szomowski Mikolaj 68

Szwarcemberg-Czerny Franciszek ?

Szymański Adam 35

Szymański Paweł 49

Szymon, reformat 214

Smiglecki Narcin 126, 172

Sniżýski 144

Swięcki Aniol 196
Ŝwierczyński, jezuita 125

Tacyt 112

Taralicz Sebastian 9 (2)

Teliga Karol 38

Temberski Stanisław 8 (8)

Teofil od św. Franciszka 192

Teofila, zakonnica 185

Theophilus a S. Francisco zob. Teofil od sw. Franciszka

Thesznarowicz Zachariasz 26

Tirczyński Walenty 219

Tobolski Jakub 14 (7)

Tomasz z Akwinu ślw. 5, 11, 12, 19, 93, $104,106,127,128,129,130,137,162$, $165,166,167,168,172,199,209$

Tomaszewski Antoni 214

Tomecki Franciszek Wincenty 31

Tomicka Zofia 186

Trębicki Wincenty 210

Trybalski Leopold 98, 99, 100 (1, 7), $101,102,103$

Tyszkiewicz Jerzy 127, 130

Ugon Herman 140

Ulatowski Adam 63

Urbański Stanisław 110

Ustiensis Jacobus zob. Jakub z Ujścia

Valerius Cornelius 2

Verner, magister 135

Vitellius Jakub 18 (4)

Vitus zob. Wit

Vycewicz (?) Marian 64

Walter Franciszek 175

Wąsowicz Bogusław 116

Wąsowicz Felicjan 24 (10, 13, 14), 190

Wencel Jan 73

Wicher Władysław 22

Wierski Jakub $222(1,4)$

Wilczek Franciszek Kazimierz 122

Wilhelm, brat 198

Wilhelmus zob. Wilhelm

Wilscius Christophorus zob. Wilski Krzysztof

Wilskj. Krzysztof 30 (7)

Wiltawski Wiktoryn $79,80,87,88$

Wjóniewski Jan 33, 60, 2:5

Wiśniewski L. 111

Wíśniowscius Silvester zob. Wiśniowski Sylwester

Wiśniowskj. Sylwester 219

Wit 64

Witkowski Marcin 40

Wocedalski. Gerard 109

Wohlweber Zygmunt 176, 177

Wojciechowski Antoni 13

Wojewódzki Pawel $9(1,4)$

Wolska, benedyktynka 144

Wroniawski Tomasz 116

Wyltawski Victorinus zob. Wiltawski Wiktoryn 
Wysocki Mikołaj 1 (4)

Zajączkiewicz $\lrcorner$ Mikołaj 149

Zalaszowski IIikołaj 14

Zaleński Michal 131

Zawisza Jan 23

Zembrzuski Kazimierz 191
Zubowski, magister 131

Zygmuntowicz Stanisław 9 (1)

Źarczyński Jan 31

Żelaśkiewicz Ildefons 224

Źyskiewicz Maciej 8 (6)

$\mathrm{Sum}$ marium

\section{DE PRAESTANTISSIMIS CODICIBUS}

\section{IN BIBLIOTHECA SEMINARII DIOECESANI SANDOMIRIAE ASSERVATIS}

Quae in Bibliotheca Seminarii Dioecesani Sandomiriensis asservantur collectiones, tum ex bibliothecis aboilitorum monasteriorum, tum donis virorum ecclesiasticorum congregantur. Codices 1825 voluminibus consitant, quorum 36 ante annum 1500 confecta sunt, 17 saeculo XVI, 293 saeculo XVII, 621 saeculo XVIII, 522 saeculo $\mathrm{XIX}, 336$ saeculo $\mathrm{XX}$ orta sunt, Hoc in thesauro 675 lingua Latina, 1121 lingua Polona, 29 aliis recentibus linguis codices exarati sunt.

Si argumentum spectaveris, ex disciplina philosophiae distinguendi sunt 145 manuscripti, quorum 53 saeculo XVII, 56 saeculo XVIII, 23 saeculo XIX, 13 saeculo $\mathrm{XX}$ conditi sunt. Ad provinciam theologiae dogmaticae pertinent 94 codices, quorum 37 saeculo XVII, 38 saeculo XVIII, 14 saeculo XIX, 5 saeculo XX compacti sunt. In serie theologiae moralis Bibliotheca tenet 61 volumina, quorum 1 saeculo $\mathrm{XV}$, 15 saeculo XVII, 23 saeculo XVIII, 15 saeculo XIX, 7 saeculo XX condita sunt. Locuples est supellex asceticae scientiae, qui integra collectione Sandomiriensium virginum monialium a $\mathrm{S}$. Benedicto dictarum videtur esse auctus, constatque 303 codicibus: 2 saeculo XV, 55 saeculo XVII, 165 saeculo XVIII, 81 saeculo XIX et $\mathrm{XX}$ ortis. Ad S. Scripturae scientias numerantur tantum 36 codices: 4 praevii saeculo XIVI, 2 orta saeculo XVIII, 24 saeculo XIX, 6 saeculo XX. Ad partem historiae ecclesiasticae annumerari possunt 613 tomi, quorum 4 saeculo $X V, 10$ saeculo XVI, 56 saeculo XVII, 110 saeculo XVIII, 248 saeculo XIX, 185 saeculo XX composili sunt. Ad ius Polonum et canonicum spectant 138 codices, quorum 2 saeculo XV, 3 saeculo XVI, 26 saeculo XVII, 65 saeculo XVIII, 28 saeculo XIX, 14 saeculo XX scripti sunt. Scientia liturgiae in Bibliotheca 131 codicibus est. ornata, quorum 3 saeculo XV, 1 saeculo XVI, 18 saeculo XVII, 69 saeculo XiVIII, 29 saeculo $\mathrm{XIX}, 1$ saeculo $\mathrm{XX}$ conditi sunt. Ad ordinem sacrae contionis 160 
volumina allegantur, quorum 16 saeculo $\mathrm{XV}, 2$ saeculo XVI, 22 saeculo XVII, 60 saeculo XVIII, 48 saeculo XIX, 12 saeculo $\mathrm{XX}$ geniti sunt. Regio catechetica distingui potest 12 codicibus, quorum 8 saeculo XVIII, 4 saeculo XIX procreati sunt. Politiorum litterarum genere 39 codices tenentur, quorum 1 saeculo XVI, 3 saeculo XVII, 7 saeculo XVIII, 22 saeculo XIX, 6 saeculo XX in lucem prodierunt. Caterva variorum manuscriptorum 103 codices recensentur, quorum 4 saeculo XV, 8 saeculo XVII, 26 saeculo XVIII, 33 saeculo XIX, 32 saeculo XX debentur. Inter quos sunt vocabularia, artis gramaticae manualia, itinerum descriptiones, compositiones e scientia rerum naturalium petitae, pericopae ex Patrum Ecclesiae operibus depromptae, hisce similia. In nonnullis disciplinarum generibus, praesertim in Ecclesiae historia, oportuit interim in Bibliotheca retinere codices et scriptionum collectiones, quae archivalia sapiebant.

Tantum 227 reperiuntur in Bibliotheca codices, qui viros doctos alliciant, qui auctoris nomen produnt aut saltem locum, quo opus ortum est. Quorum codicum 75 clero dioecesano et auctoribus profanis, ceteri viris familiae religiosae addictis inscribuntur. Ab Academia Cracoviensi eiusque scholarum Bibliothecae sunt 33 volumina, ab Catholico Maximo Lyceo Lubliniensi 1, a Sacra Academia Petropoli 3, a Seminario dioecesano Sandomiriae 6, a Seminario dioecesano Seinae 1, ab Universitate et Sacra Academia Varsaviae 8, ab Universitate Vilnae 1, ab Academia Samoscii 1, ab auctoribus non scholae scribentibus et unde manserint, incertis 21 codices.

Abolitorum monasteriorum collationes inferuntur Bibliothecae Seminarii, quae aucta est his ordinum codicibus: a Fratribus Minoribus de Observantia cedunt 20 manuscripta - 1 Grodna, 5 Cracovia, 3 Opatovia, 3 Paradiso, 2 Pryrovia, 4 Radomia, 1 Tarnovia, 1 Vilna, 1 incerto loco allatus est. Ordinis Praedicatorum patres auctores sunt 12 codicum, quorum 1 Brestia Cuyaviae, 1 Lubino, 6 Sandomiria, 1 Alto Colo, 3 ab incertis monasterils oriuntur. Fratrum Minorum Conventualium 1 tantum Calissia oriundus codex invenitur. Plurima, nam 83 volumina, praebuerunt Societatis Iesu abolitae domus, quorum 1 Brunsberga, 1 Iaro.. slavia, 3 Calissia, 2 Cracovia, 5 Lublino, 3 Leopoli, 1 Ostrogia, 1 Petricovia, 6 Posnania, 1 Pultovia, 3 Resela, 20 Sandomiria, 1 Schotlandia, 2 Tyrnavia, 13 Varsavia, 3 Vilna, 3 Vratislavia, 13 incertis locis oriuntur. Ab conventu Congregationis Bartholomaei Holzhauser Vengroviae 1 codex allatus est. A Congregatione Missionum a S. Vincentio dicta 4 codices: 1 Cracovia, 2 Lovicia, 1 Premislia. Patres a S. Paulo I Eremita dictos 1 tantum codex incerti loci originis monstrat. Patres Scholarum Piarum auctores 14 codicum sunt, quorum 1 Monte Calvariae, 2 Lovicia, 2 Podolino, 3 Radomia, 2 Resovia, 4 Varsavia vecti sunt. Abolitis monasteriis Fratrum Minorum Strictioris Observantiae missi sunt in hanc Bibliothecam 15 manuscripta, quorum 1 Biecia, 1 Casimiria, 3 Cracovia, 1 Lublino, 1 Osieczyno, 2 Pinciovia, 4 Sandomiria, 1 Solcia, 1 Varsavia. 
Peculiari memoria digni sunt XV saeculi codices, qui notissimorum auctorum et ignotorum praebent cpera. Nonnulla eorum ostendunt inter provincias Poloniae ' mediae et Silesiam fuisse necessitudines. Multi codices praebent notitias ad vitas exarandas virorum doctorum et iuventutis magistrorum ac moderatorum suntque iudicio in Polonia scientias theologicas erevisse. 